\title{
ابن الحَجَّام القيرواني المالكي وأثره في الحياة العلمية بإفريقية والأندلس منذ أواخر القرن الثالث حتى منتصف القرن الرابع الهجريين
}

دانور هان ابراهيم سلامه

\section{ملخص عربي}

كان الفقبه عبد الله بن مسرور القيرواني المعروف بابن الحَجَّامِ (ت؟؟به/901م)، من شيوخ المالكية الثقات الذين نقل عنهم العلم. وقد تتلمذ عليه كثير من طلاب العلم القيزو انيين والأندلسيين، فسمعوا منه مصنفاته العلمية، وكتب الفقه المالكي، ومصنفات ابن سنجز الجُرجاني نزيل مصر ، وهى مفقودة، برواية شيخه عيسى بن مسكين،

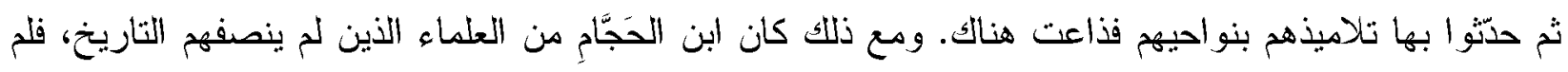
ينل قدره من الاهتمام الذي يتتاسب وقيمته العلمية. وتستهدف الدراسة إبراز ملامح دوره في الحياة العلمية بإفريقية والأندلس، وأثزه في تثكيل ثقافة تلاميذه منذ أواخر القرن الثالث حتى قرابة منتصف القرن الزابع الهجريين، مما أهل بعضهم ليصبحوا من أبرز شيوخ الفقه والحديث ببلادهم. وتستهدف الدراسة أيضًا إبراز موقف ابن الحَبَّمٍ المعارض للمد الثيعي الفاطمي بإفريقية وتأثر تلاميذه القيروانيين بذلك، وميله نحو الزهد و اقتداء تلاميذه القيرو انيين و الأندلسيين به.

\section{Abstract In English}

The jurist Abdullah ibn Masror al- Kairouani, known as Ibn al- Hajjam (T346Ah/958 $A D)$, was one of the reliable Maliki sheikhs who were transferred from the flag, and many students of the Kairouan and Andalusian sciences studied it. They heard from him his scientific works, the books of Maliki jurisprudence, and the works of Ibn Sinjar al- Gurgani, the guest of Egypt, which is missing, in the novel of his sheikh Isa ibn Miskine, and then they talked to their disciples in their areas, and they went there.

Nevertheless, Ibn al- Hajjam was one of the scholars who had not been distinguished by history, and he did not receive the attention commensurate with its scientific value. The study aims to highlight the features of his role in the scientific life of Africa and Andalusia, and its impact on the formation of the culture of his disciples from the late 3rd century until the middle of the fourth century Hijri, which qualified some of them to 
become the most prominent elders of jurisprudence and hadith in their country. The study also aims to highlight ibn al-Hajjam's position opposed to the Fatimid Shiite tide in Africa, influenced by his Kairouan disciples, and his propensity for asceticism and the example of his Kairouan and Andalusian disciples.

\section{المقدمة}

يذخر تاريخ الإسلام بشيوخ كبار أجلاء برزوا في العلوم الاينية، كالفقه، وعلوم القرآن الكريم، والحديث،

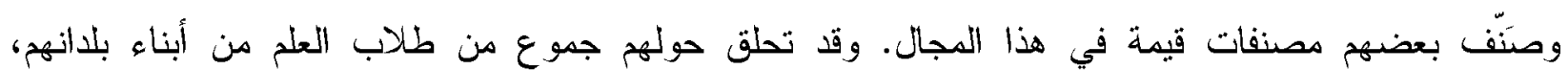

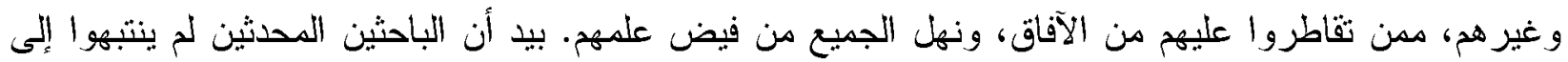
بعض أولتك العلماء، وغفلوا عن تتاول سير هم، ولم يسلطوا الضوء على مصنفاتهم ومروياتهم، ودورهم في التكوين العلمي لتلاميذهم، فصار بعضهه من العلماء المنسيين، رغم أثرهم العميق في الحياة العلمية ببلدانهم و غيرها من الأقطار من خلال تلاميذهم بها. وكان الفقيه عبد الله بن هاتشم بن مسرور القيرواني المالكي المعروف

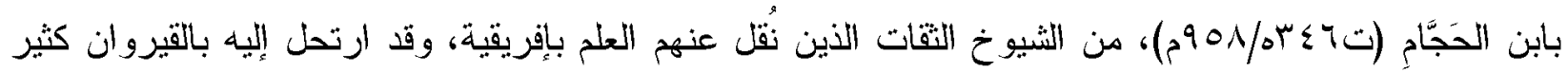
من طلاب العلم. ومع ذلك كان ابن الحَجَّامِ من العلماء الذين لم ينصفهم التاريخ، فلم ينل قدره من الاهتمام الذي يتناسب وقيمته العلمية.

وفي ذلك السياق تسلط الدراسة الضوء على صفحة منسية من صور التو اصل العلمي بين إفريقية والأندلس منذ أواخر القرن الثالث حتى قرابة منتصف القرن الر ابع الهجريين؛ فهى تتتاول سيرة ابن الحَجَّمِ المالكي وآثاره العلدية، ومروياته عن مشاهير شيوخه، وذيوعها في إفريقية والأندلس، وموقفه المعارض للمد الثيعي ورجال الدولة الفاطمية بإفريقية وتأثر تلاميذه القرو انيين به، إذ أغفلت الدراسات المختصة بالصراع المذهبي بين المالكية و الثيعة في إفريقية ذلك'. وستكثف الدراسة عن ميل ابن الحََّّام نحو الزهد واقتداء تلاميذه القيروانيين

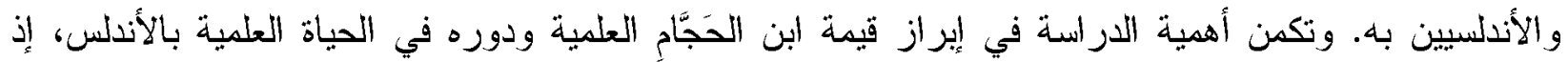
أغفل الباحثون المتخصصون في دراسة التأثيرات الحضارية المتبادلة بين بلدان العالم الإسلامي أثزه في تثكيل

راجع: عبد العزيز المجدوب، الصر اع المذهبى بإفريقية إلى قيام الدولة الزيرية، الطبعة الثانية، الدار التونسية للنشر،

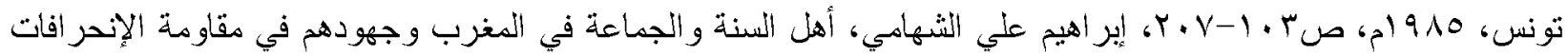

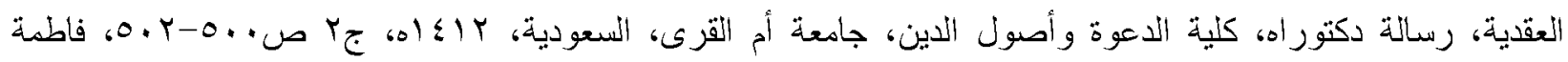

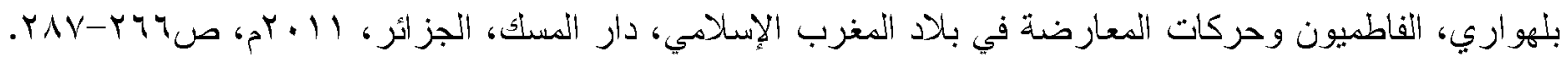


ثقافة طلاب العلم الأندلسيين؛ فلم يُشر إليه محمود علي مكي في دراسته القيمة عن التيارات الحضارية المشرقية في الأندلس، كأحد شيوخ الفقه القيروانيين الذين درس عليهخ أولئك الطلاب في طريقه إلى المشرق لطلب العلم

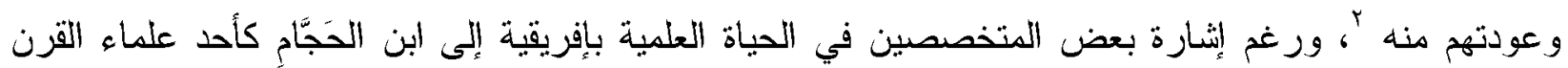

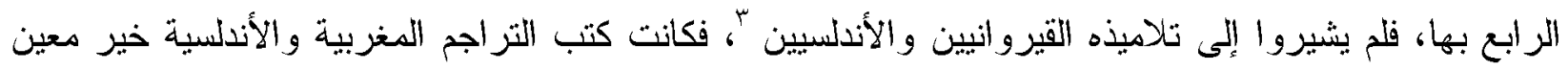
لهذه الدر اسة للتعريف بهم، وعلى ددى استفادتهم منه، وتأثر هم به.

وارتكزت الدراسة على المنهج التاريخي القائم على الوصف، والتحليل، والاستقراء للمصادر الأولية التي ترجم بعضها لابن الحَجَّامِ، وتضمنت إثـار ات عن شيوخه، وتلاميذه القيروانيين والأندلسيين، واحتوى بعضها الآخز على روايات مهمة عن الحركة العلمية في الأندلس، وبلدان المغرب، ومصر، والحجاز، وغيرها، حتى

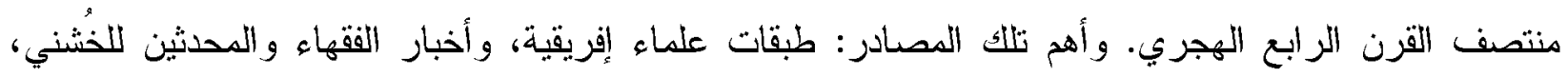
وتاريخ علماء الأندلس لابن الفرضي، ورياض النفوس للمالكي، والتمهيد لما في الموطأ من المعاني والمسانيد لابن عبد البر القرطبي، وجذوة المقتبس للحُميدي الميورقي، ونرتيب المدارك للقاضي عياض، وفهرسة ابن خير الإشبيلي، ومعالم الإيمان للاباغ. ووقفت على مادة علمية ثرية تخدم موضوع الدراسة فى كتب التراجم المشرقية، ومنها: تذكرة الحفاظ، وسير أعلام النبلاء للذهبي، وتجريد أسانيد الكتب المشهورة والأجزاء المنثورة لابن حجر العسقلاني، و غير ها، و أفاد كتاب توضيح المشتبه لابن ناصر الدمثقي في غير موضع من الدر اسة. وقسمت الدر اسة إلى مقدمة، ودر اسة تمهيدية، وسبعة مباحث. وتضمنت المقدمة موضوع الدر اسة، و أهميتها، ومنهجها، وأهم مصادر ها. وتحدثت في الدراسة التمهيدية عن الددرسة الفقية المالكية التي انتسب إليها ابن الحَجَّامِ و هيأت له التأثير بعدق في الحياة العلمية بإفريقية و الأندلس، فأشرت إلى نشأة تلك الددرسة في البلدين وازدهار ها

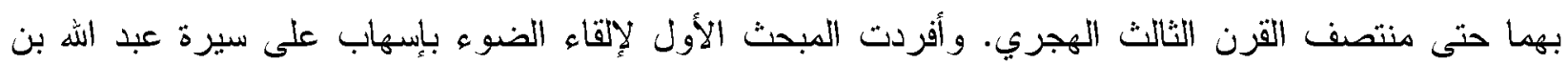
مسرور القيرواني المعروف بابن الحَجَّام، وخصصت المبحث الثاني للحديث عن جلوسه لنشر العلم بالقيروان، و التعريف بتلاميذه المغاربة والأندلسيين، وأثرت في المبحث الثالث إلى منهج ابن الحََّّامِ في رواية الحديث

Makki (Mahmud Ali), Ensayo sobre las aportaciones orientales en la Espana Musulmana, Madrid, 1968.

" يوسف أحمد حوالذه الحياة العلمية في إفريقية منذ إتمام القتح وحتى منتصف القرن الخامس الهجري، جامعة أم القرى،

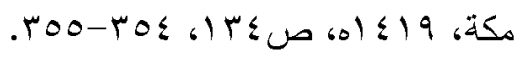


ووجوه استفادة تلاميذه منه، فإذا ما كان المبحث الرابع كثفت عن موقفه من التيار الثيعي في إفريقية، ثم تحدث

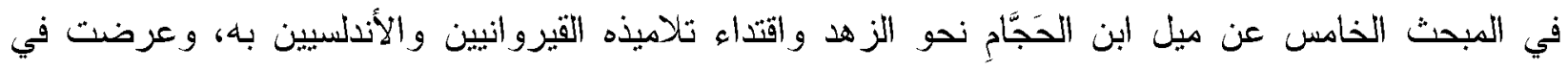
المبحث السادس لمروياته التي نقلها عنه طلاب العلم الأندلسيين إلى بلادهم وقاموا بنشر ها هناك، وفي المبحث

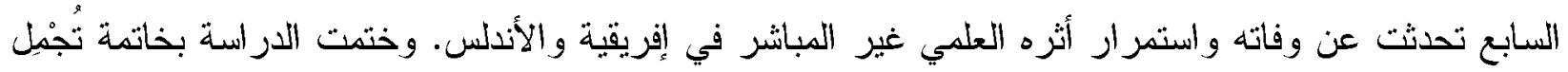
أغر اضها واستتناجاتها، ثم أوردت ثبتًا بالمصادر الأصلية، وأمهات المر اجع العربية، و المعربة، والأجنيية.

\section{الأر اسة التمهيدية}

\section{نثأة المدرسة المالكية في إفريقية والأدلس وازدهارها حتى منتصف القرن الثالث الهجري}

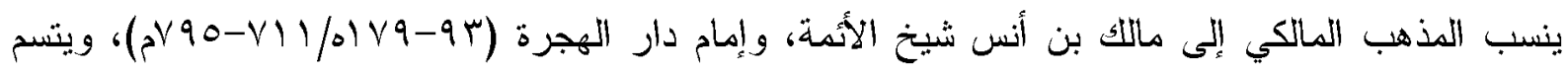

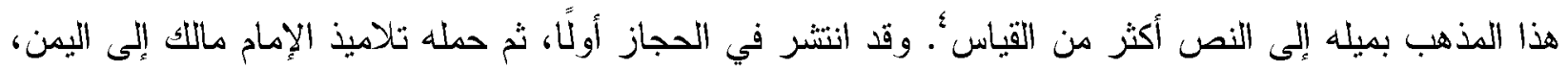
و العراق، وبعض نواحي بلاد فارس، والشام، وقد انتثر بمصر وغلب عليها وأطبق أهلها على الآتداء بهه

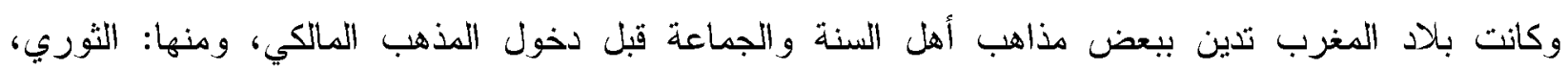
و الأوز اعي، والحنفي، وقد كتف القاضي عياض عن ذلك، فقال: " وأما إفريقية وما ور اءها من المغرب فقد كان

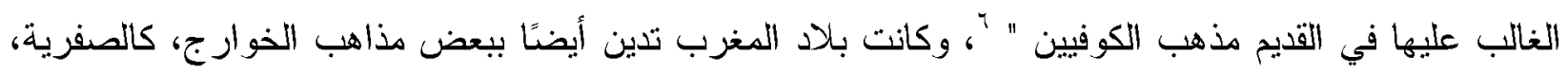
و الإباضية. وقد نشأت المدرسة الفقهية المالكية بإفريقية على يد تلاميذ الإمام مالك القيروانيين الذين رحلوا إليه بالمدينة وسمعوا منه، وأخذوا عنه، وعادوا إلى القيروان يبثون علمه وينشرون فقهه، فقد هيأت الرحلة في طلب العلم

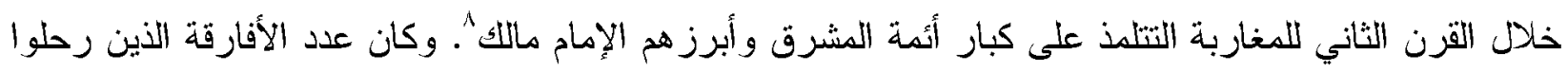

ع نز اجمه مبثوثة في مظان مشرقية ومغربية كثيرة. وأوفى ترجمة له عند القاضي عياض (ترثيب المدارك وتثريب المسالك

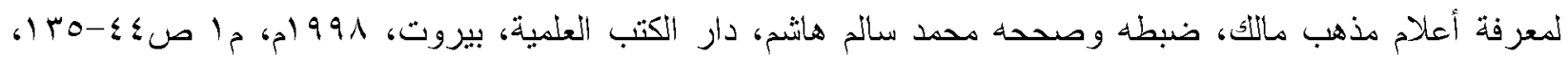

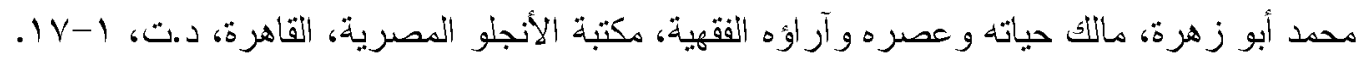

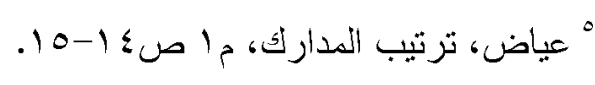

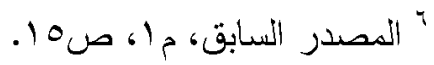
ل لمزيد من التفاصيل عن انتثار مذاهب الخو ارج الصفرية والإباضية في بلاد المغرب، راجع: محمود إسماعيل، الخوارج

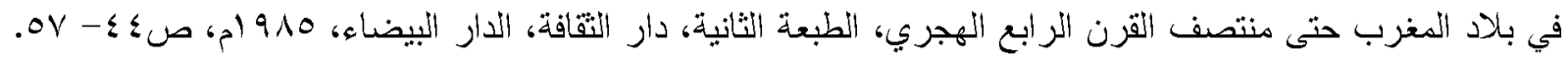

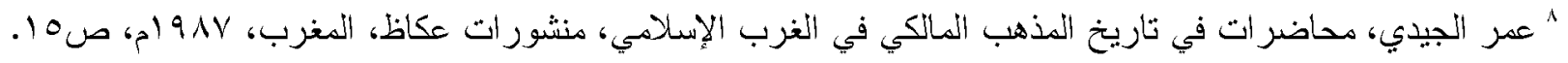


إليه يربو على الثلاثين، وفي ذلك يذكر عياض نقًا عن الخشني: " كانت إفريقية قبل رحلة سحنون قد غمرها مذهب مالك بن أنس، لأنه رحل منها أكثر من ثلاثين رجلًا، كلهم لقي مالك بن أنس، وسمع منه، وإن كان الفقه

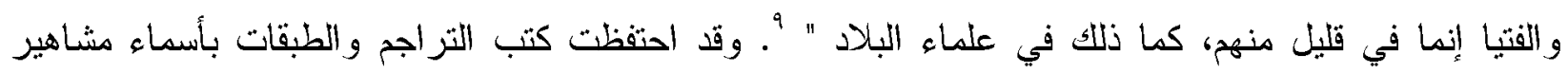

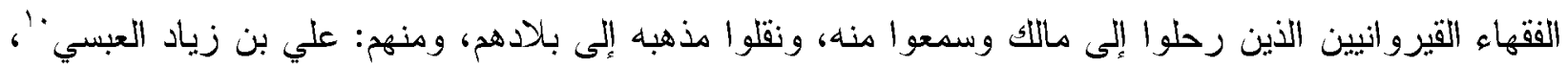

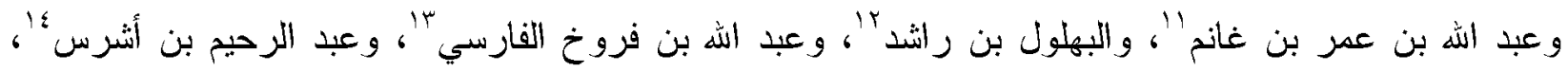

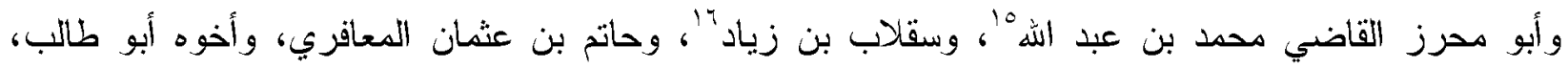
و عنبسة بن خارجة، وعبد الله بن أبي حسان اليحصبي، ورباح بن ثابت، وعبد الله بن أبي غسان، وعبد الرحمن

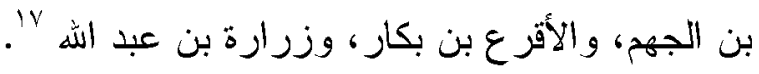

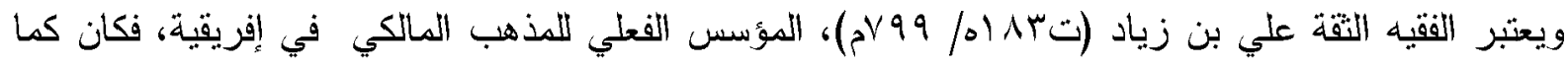

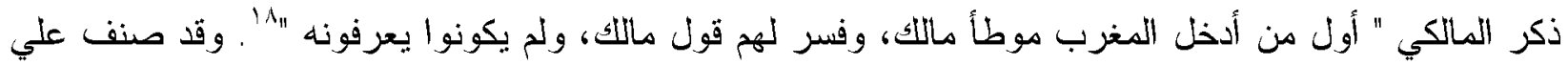
بن زياد كتابًا بعنو ان " خير من زنته " صنف فيه مسائل الفقه المالكي وبوبها، وخرجها كتبًا على مو اضيع الأحكام

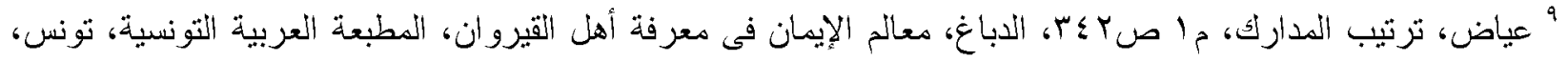

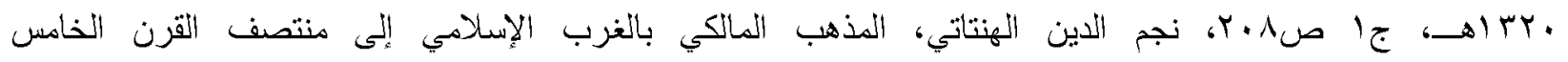

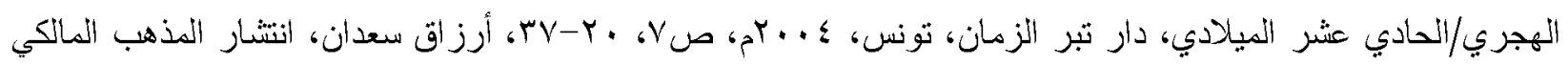

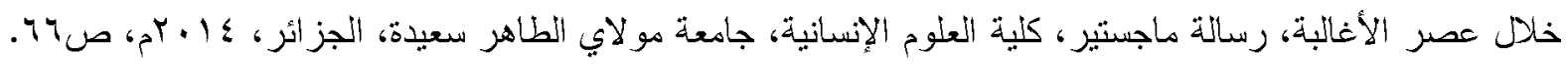

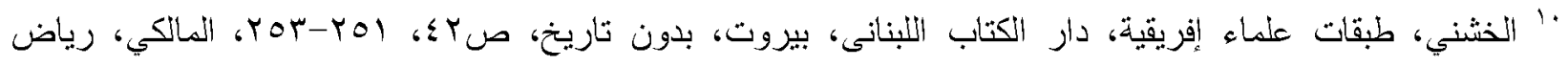

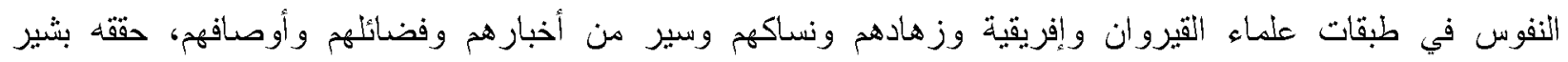

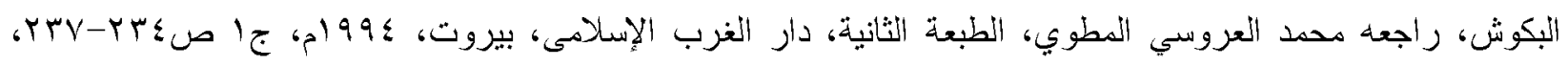

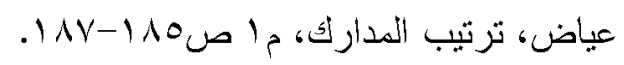

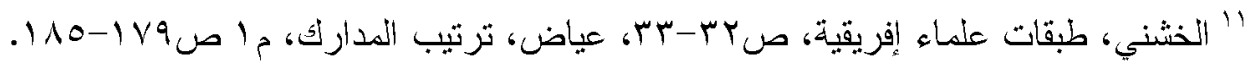

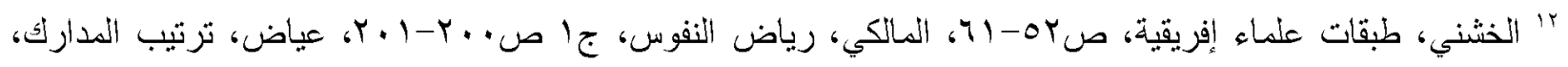

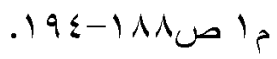

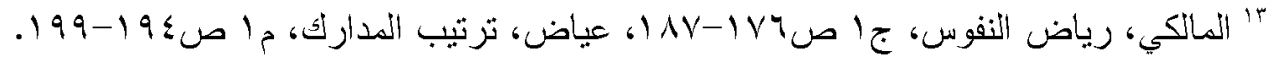

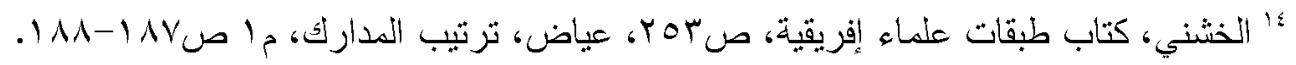

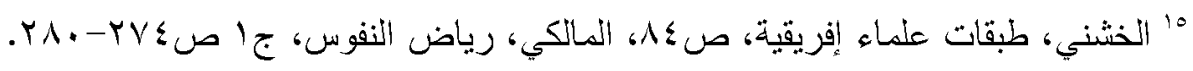

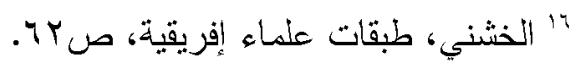

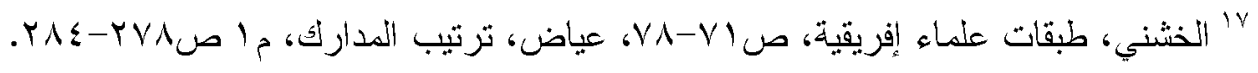

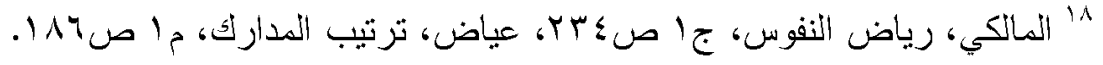




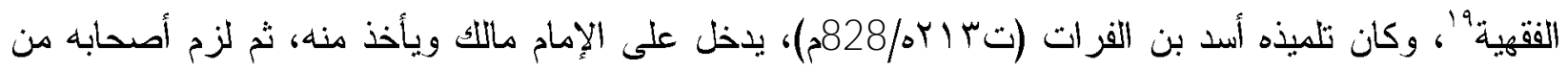

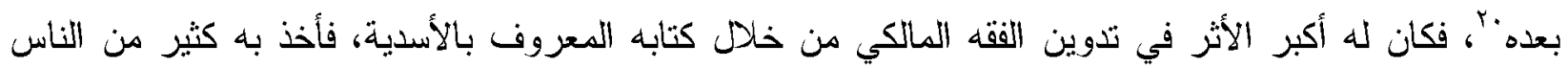

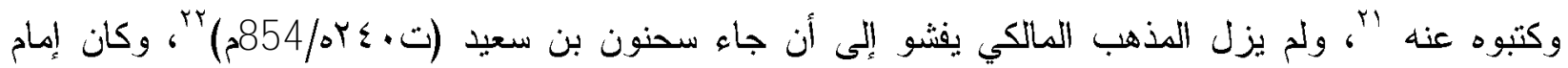

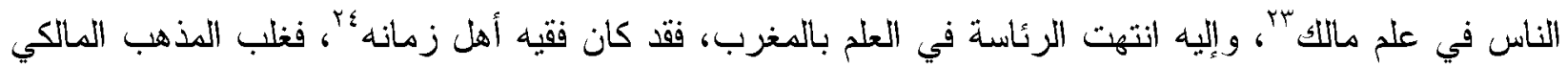

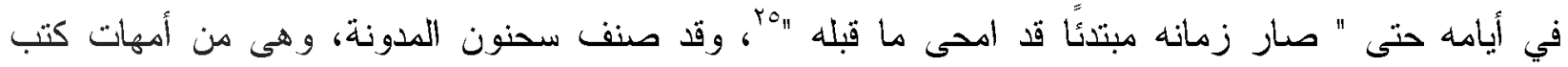
المذهب المالكي، وأصله المرجح روايتها على غيرها عند المغاربة، ولم يكن بعد الموطأ ديوان في الفقه أفيد

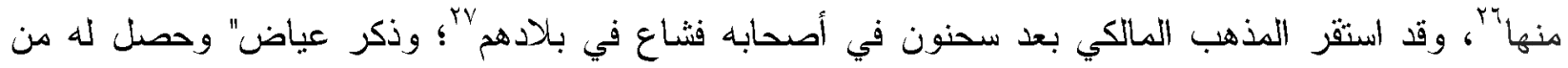

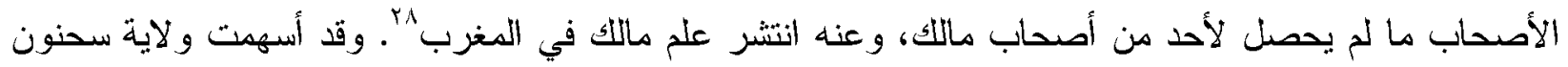
للقضاء وتقليده أصحابه في المناصب الدينية في غلبة المذهب المالكي، ثم نشأ الناس كما ذكر ابن حزم الأندلسي

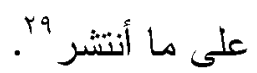

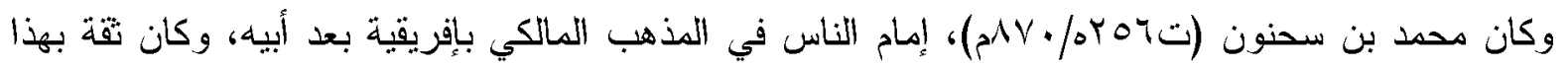
المذهب مدافعًا عنه، وكان عالمًا مبرزًا، ولم يكن في عصره أحذق بفنون العلم منه، و ألف مصنفات كثيرة في الفقه عامة، والمالكي خاصة، منها: كتابه المشهور الجامع، وجمع فيه فنون العلم و الفقه، وكتاب تفسير الموطأ أربعة

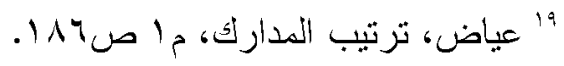

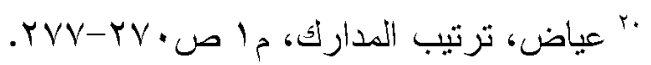

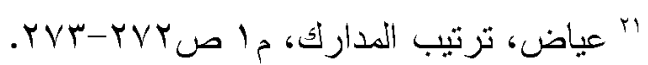

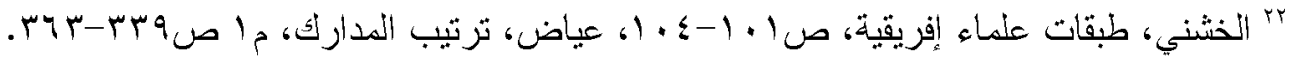

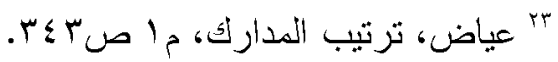

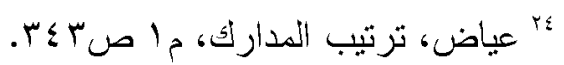

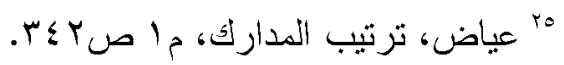

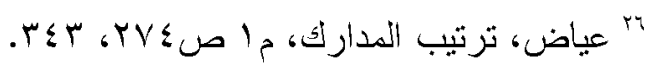

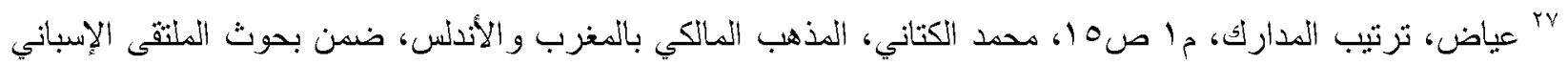

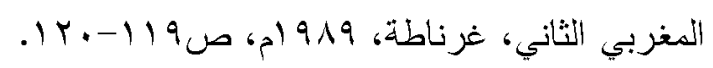

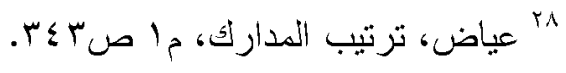

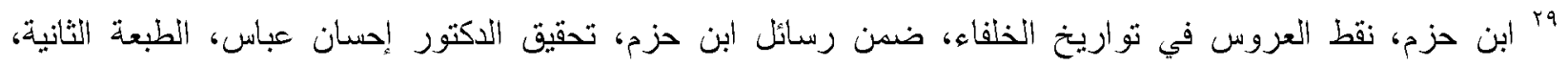

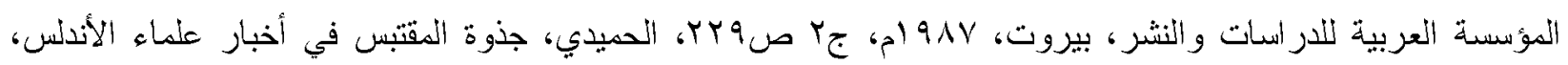

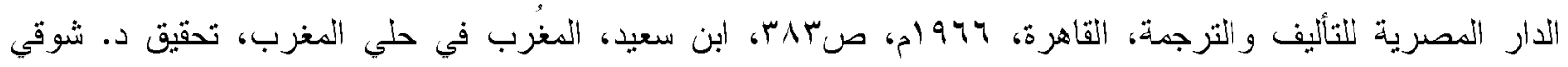

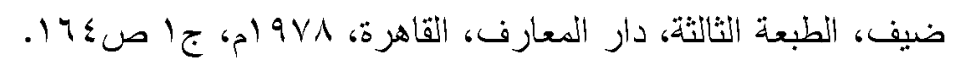


أجزاء، فانتفع الناس منها ·ب. ويعزى انتشار المذهب المالكي في إفريقية أيضًا إلى تلاميذ مالك المدنيين الذين

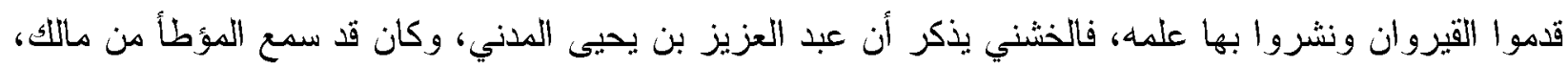

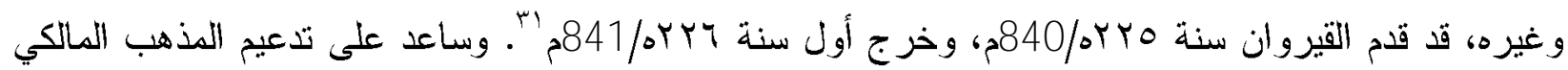
وتتييته في إفريقية تأييد وتعاطف الحكام الأغالبة معه بسبب انتشاره الواسع في أوساط السكان، والدور الذي كان

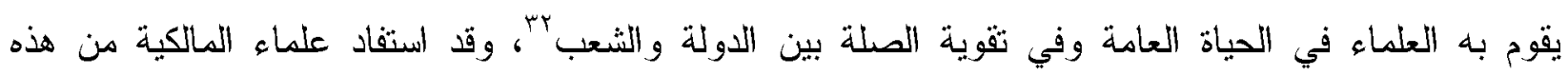
الوضعية الملائمة لتركيز المذهب المالكي، ومنع حلقات الصفرية، والإباضية، و المعتزلة، بجامع القيروان بـان. وحين بدأت بلاد الأندلس بالانفتاح على الحضارة الحجازية في عهد الأمير الأموي هشام الرضا (VY) . . .

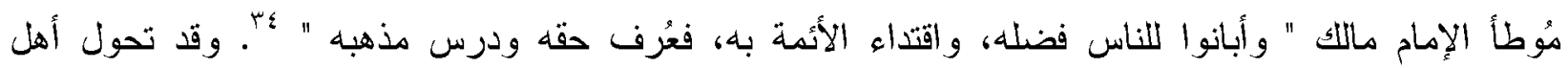
الأندلس عن الدذهب الأوزاعي حين اعتد الأمير هشام الرضا المذهب المالكي مذهبًا رسميًا للأندلس، و أخذ الناس جميعًا بالتزامه " وصيّر القضاء و الفتيا عليه " هبّاء ومن أعلام المالكية الأندلسيين الذين لقوا مالكًا وسمعوا منه:

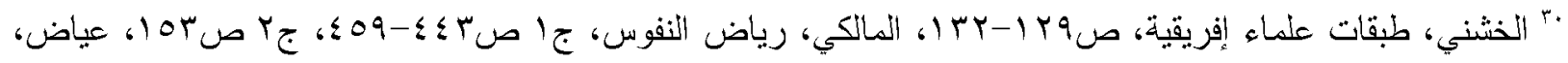

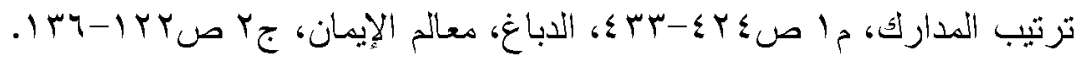

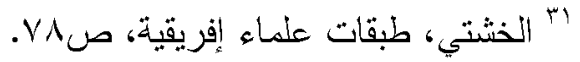

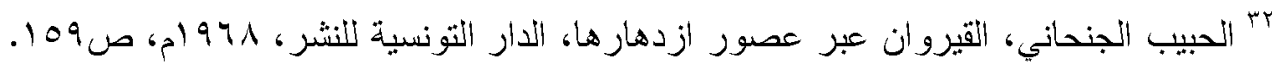

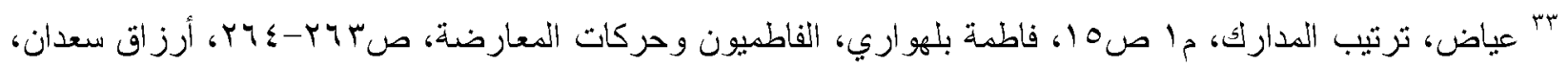

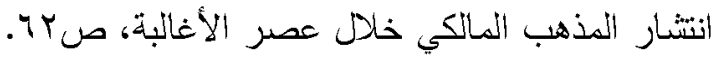

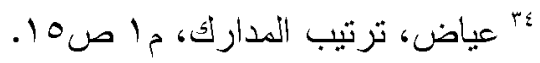

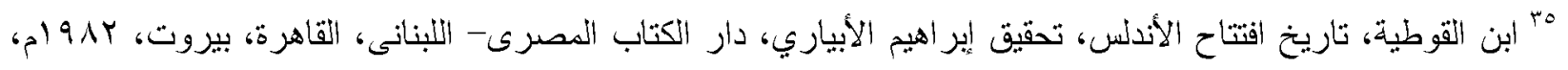

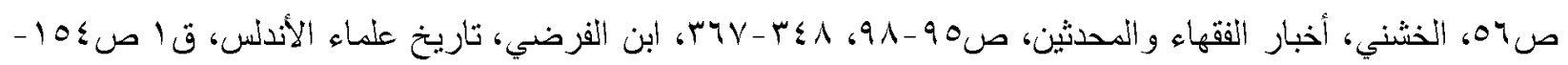

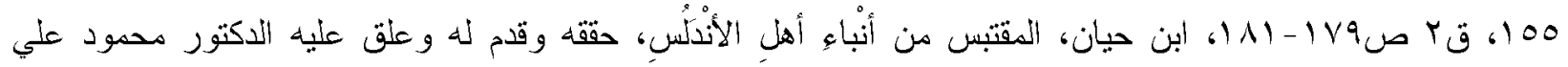

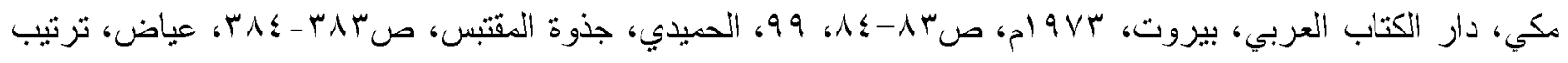

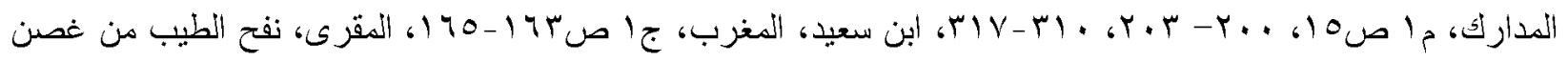

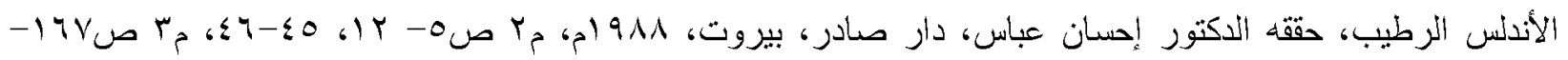

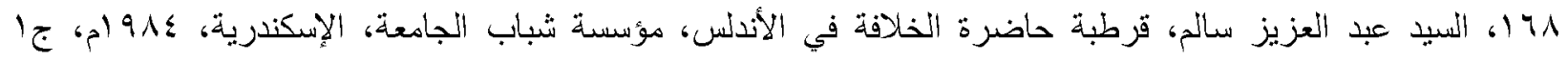
صـ 0- 00، مصطفى الهروس، المدرسة المالكية الأندلسية إلى نهاية القرن الثالث الهجرب، نشأة وخصائص، وزارة

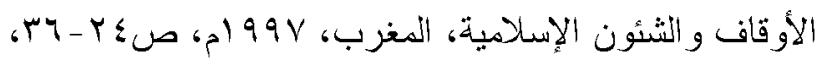


الغازي بن قيس القرطبي، وقد انصرف إلى الأندلس بعلم عظيم، نفع الله به أهلها، وهو أول من أدخل موطأ مالك

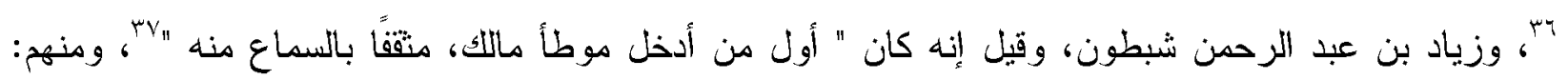

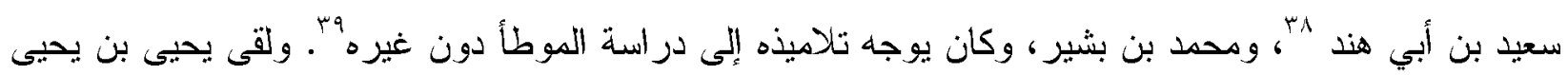

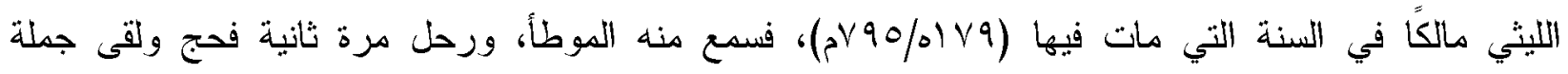

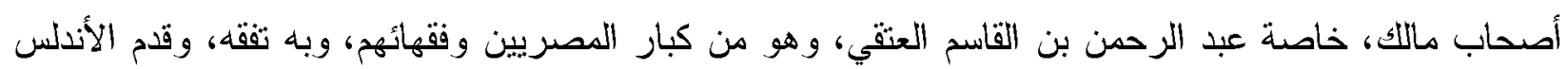

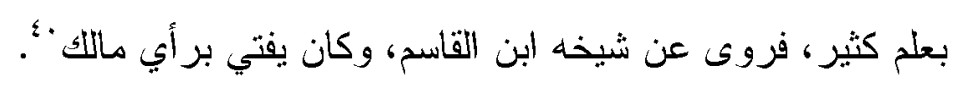

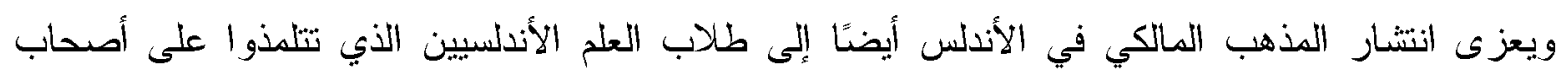
الإمام مالك؛ فقد صحب عيسى بن دينار (ت / أr/027م)، عبد الرحمن بن القاسم ولزمه بمصر، وعول عليه،

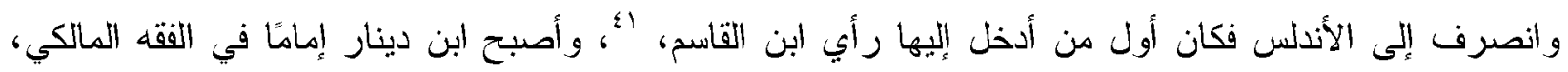

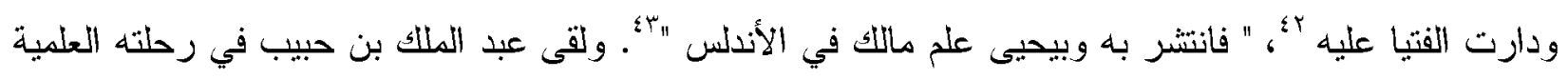

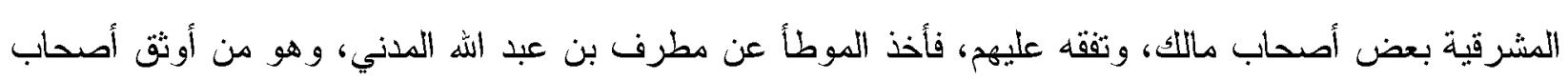

Lopez Ortiz (J ose), La recepcion de la Escuela Malequi en Espana, Madrid, 1930, pp.143 152, Lévi Provençal, Historia de Espana, por Ramon Menedes Pidal, Madrid, 1957, pp.96- 98, Makki, op. cit., 90- 98.

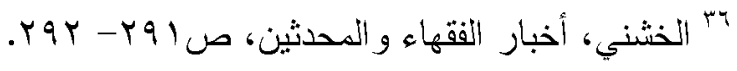

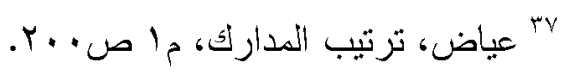

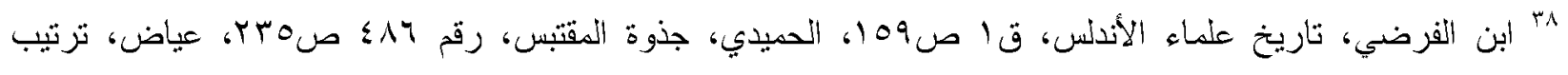

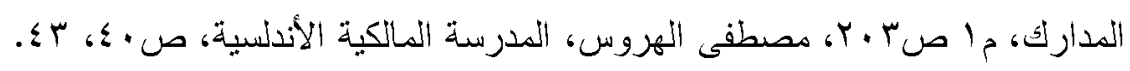

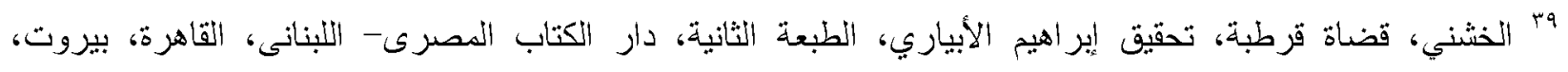

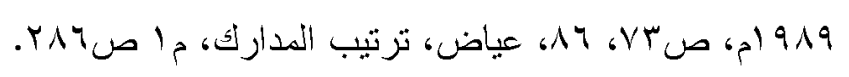

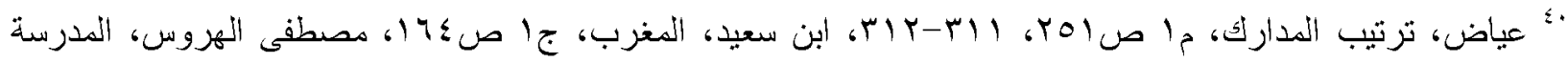

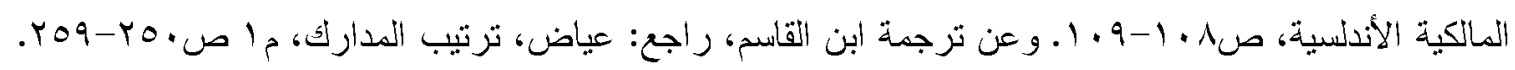

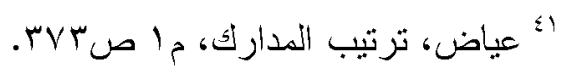

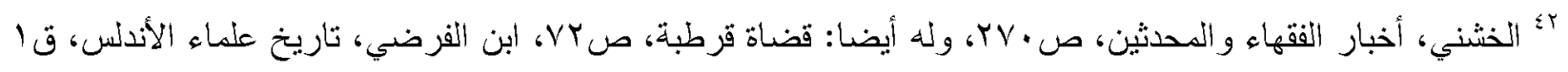

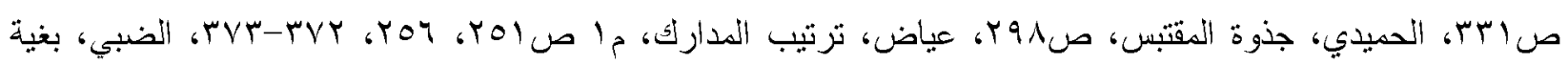

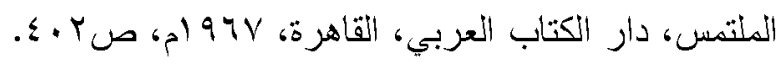

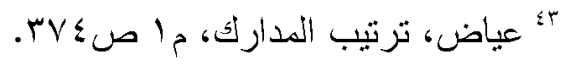


مالك، و انصرف عائدًا إلى الأندلس وقد جمع علمًا عظيمًا، هيأه ليصبح من الحفاظ للفقه المالكي النابهين فيه،

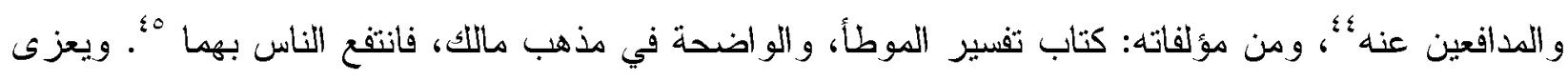
انتشار المذهب المالكي في الأنلس أبضيًا إلى الإمام سحنون بن سعيد؛ فقد رحل إليه بالقبيروان كثير من طلاب

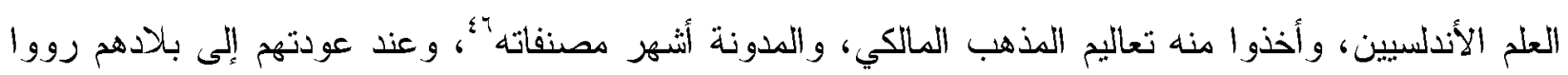
عنه". وختامًا: فقد كان تعضيد الحكام الأمويين للمذهب المالكي وعلمائه على حساب المذاهب الأخرى، سبيًا في انتتاره و هيمنه في الأندلس، ودلل ابن حزم على ذلك بقوله: " مذهبان انتشرا في بادئ أمرهما بالسياسة

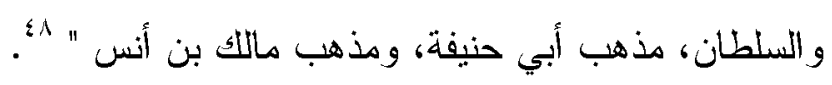

(1) سبرة عبد الله بن مسرور القيرواني المعروف بابن الحَبَّامِ

\section{1/1 1/ اسمه وكُنيته ونسبه ولقبه}

عبد الله بن أبي القاسم (أبي هاشم) مسرور مولى بني عبيد التجيبي، المكنى أبي محمد، المعروف بابن الحَجَّام

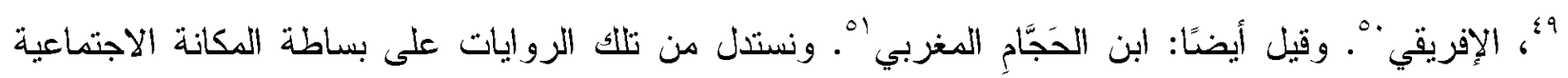

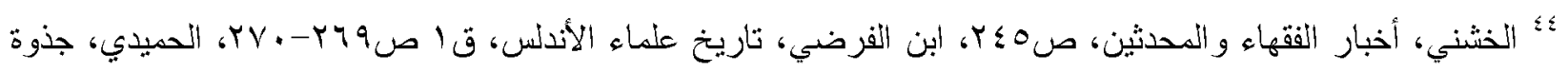

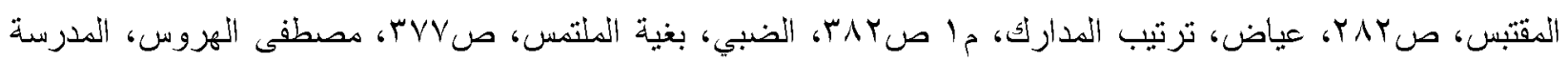

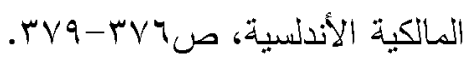

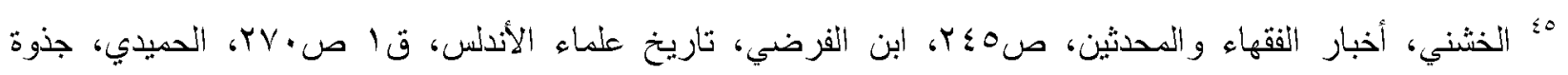

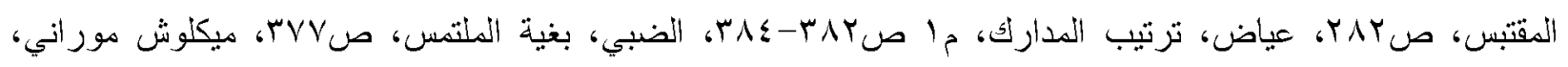

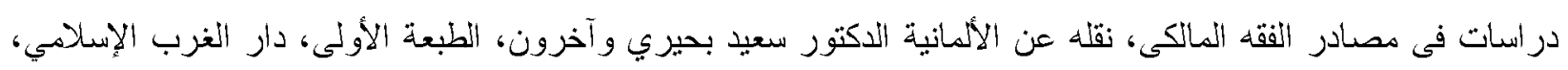

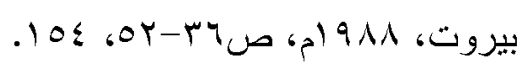

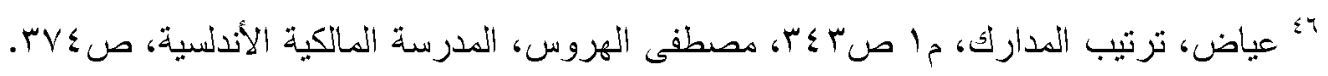

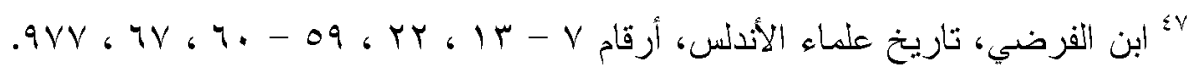

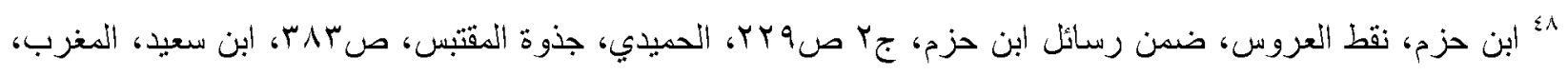

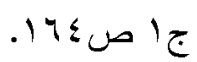

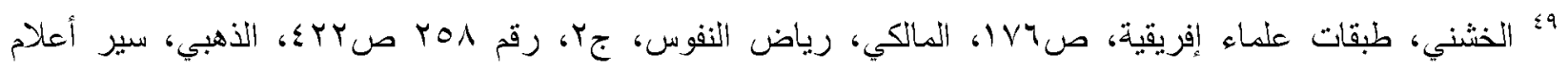

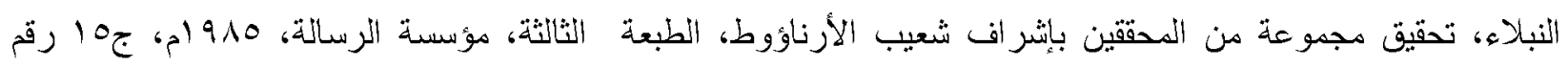
0.00 Y Y 04

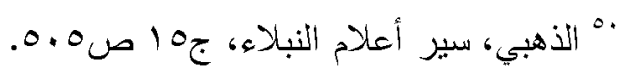


لأسرة عبد الله بن مسرور؛ فو الده كان من الموالي، وكان بمتهن مهنة الحَجَّمِة، ولُقب عبد الله بن مسرور بابن الحَجَّامِ فيما يبدو ، لاشتغال و الده بتلك المهنة.

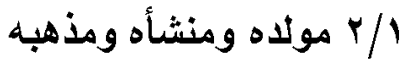

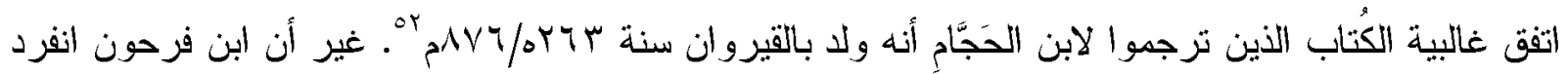

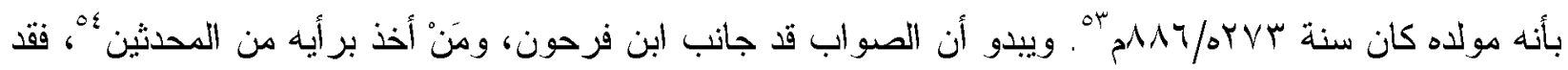

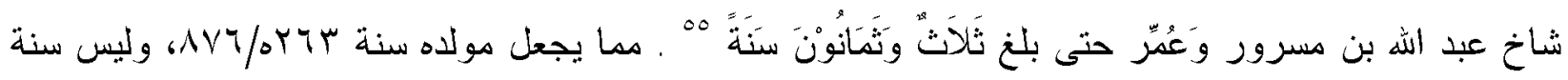

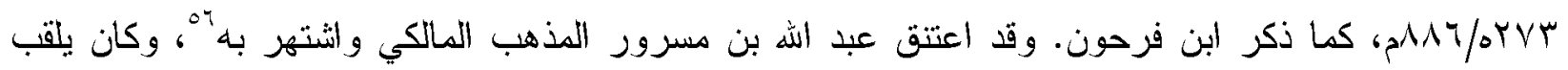
بشَنْخ المالكية بِالقبروان 1/ تكو ينه العلمي بإفريقية ورحلته إلى مصر ومر اكز التقافة الإسلامية المشرقية 1/\%//

نستدل من الروايات أن ابن الحَجَّامِ طلب العلم وبدأ السماع في سن صغيرة؛ وأنه كان يفهم ويضبط فيما

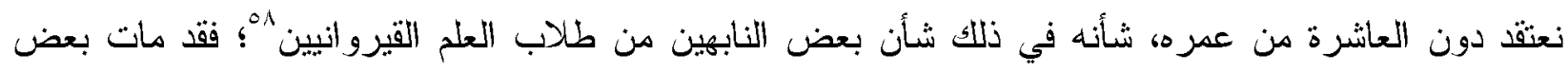

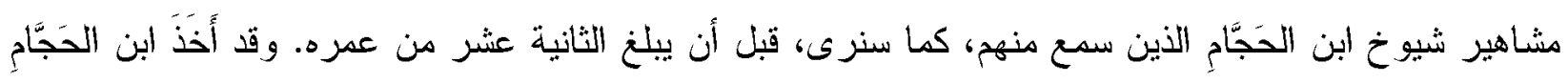

اه محمد بن عبد الرحمن المغر اوي، موسوعة مو اقف السلف في العقيدة والمنهج و التتربية، المكتبة الإسلامية للنشر، القاهرة،

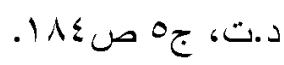

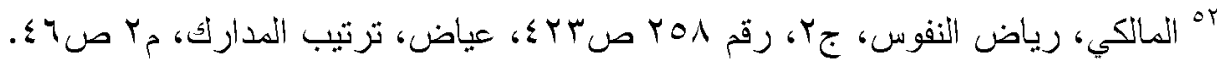

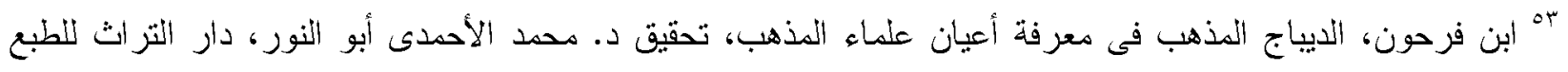

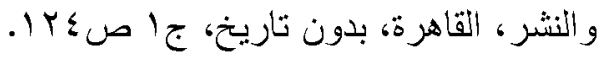

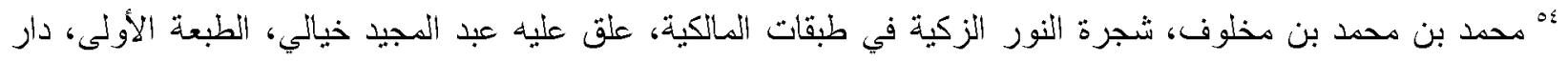

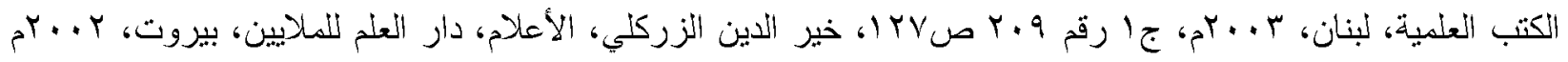

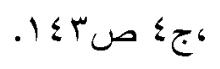

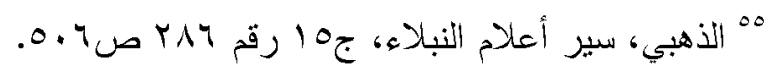

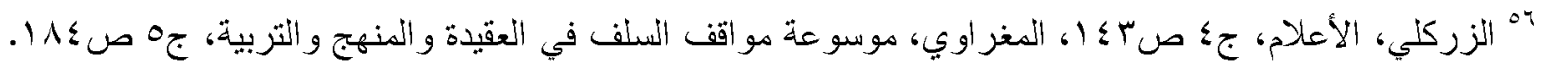

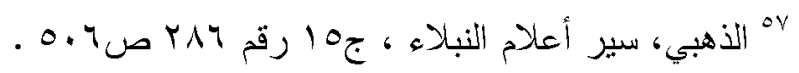

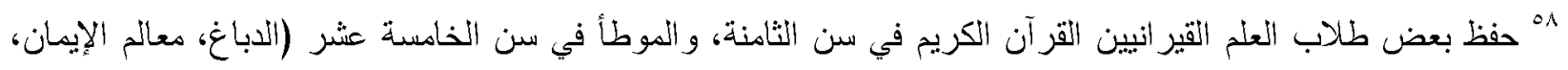
(T) 


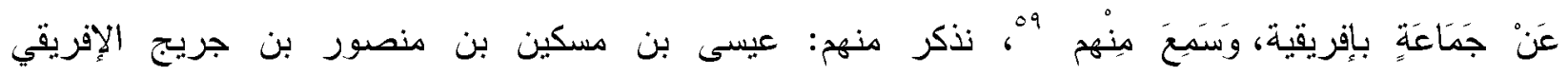

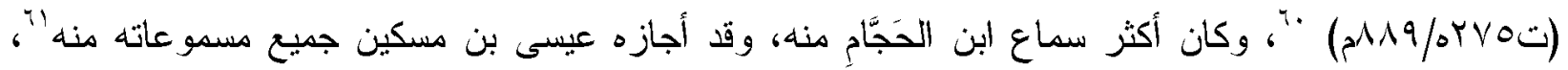

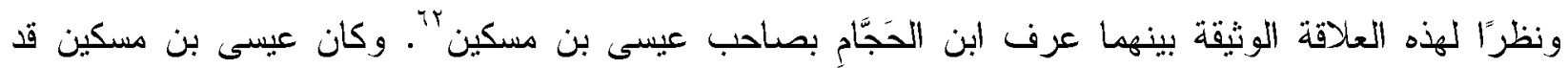
انصرف من رحلاته العلمية المشرقية إلى إفريقية بعلم كثير ، وأقام بكورة الساحل بإفريقية"، يفتي الناس ويُحدثه،

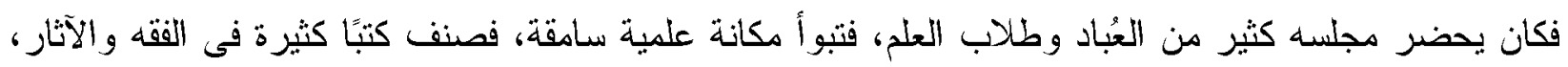

9. رغم أن المالكي قد ترجم لابن الحجام، غير أند لم يذكر شيوخه، واكتفى بقوله: " سمع من جماعة " (رياض النفوس، مج ص صYr)

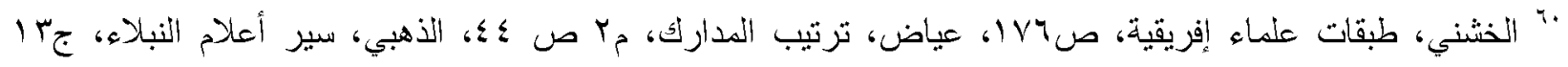

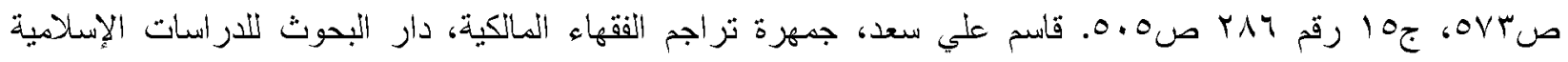

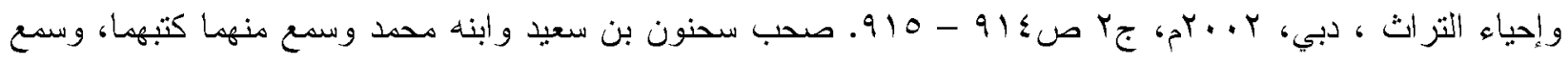
أيضًا من غير هما من علماء القيروان، و المغرب. ورحل فسمع بمصر من الحارث بن مسكين، ومحمد بن عبد الله بن عبد

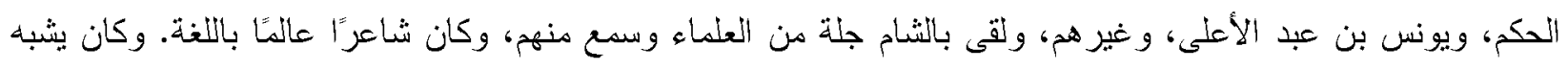

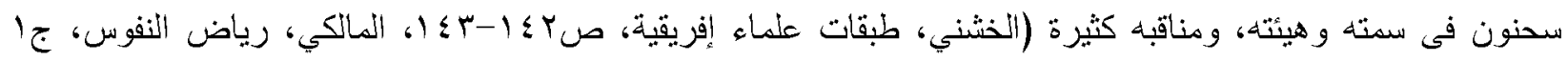

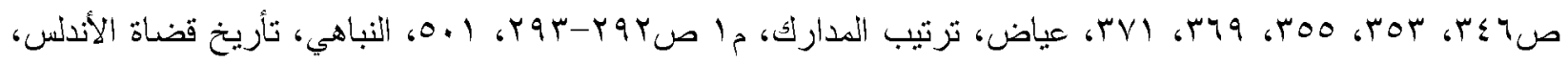

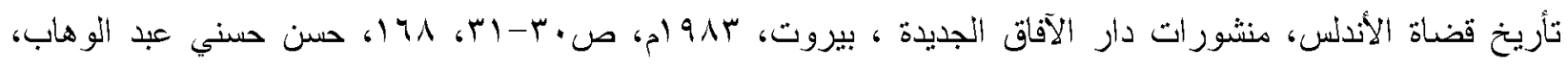

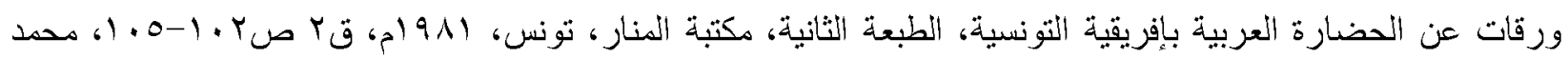

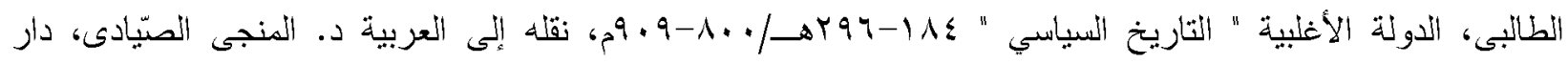

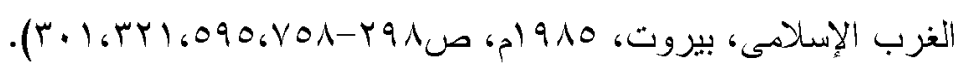

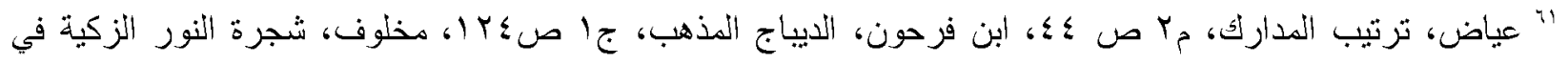

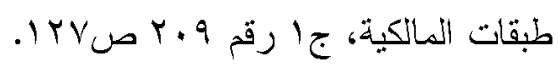

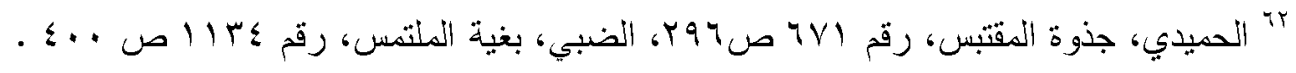

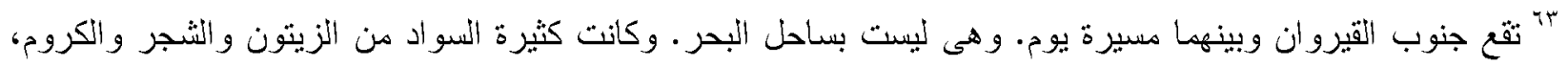

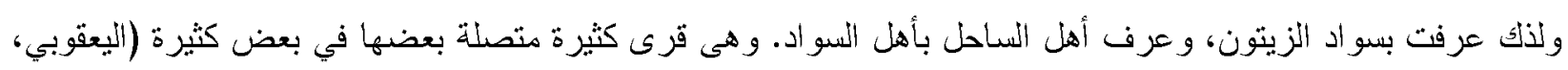

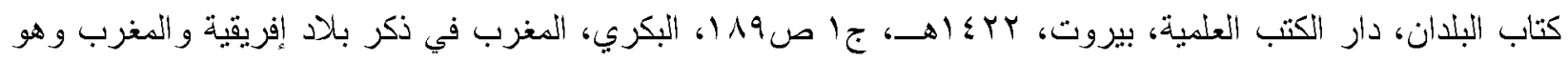

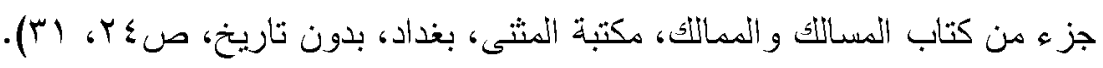


وكان متفننًا فى الحديث، و الفقه، وأسماء الرجال وكناهم، وقويهخ وضعيفهج، وكان تقة مأمونًا، فصار شيخ المالكية

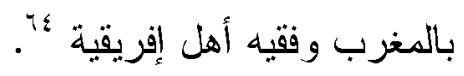

وسمع ابن الحَجَّامِ أيضًا من بعض الفقهاء التقات، نذكر منهم: أحمد بن موسى بن مخلد المعروف بعيشون

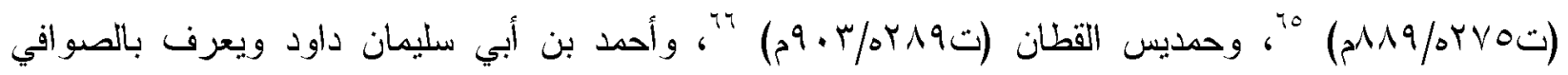

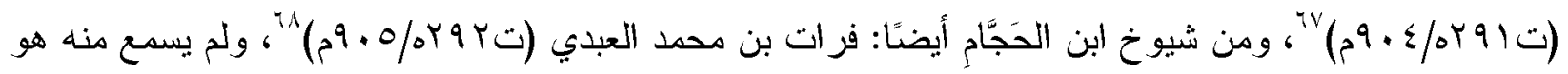

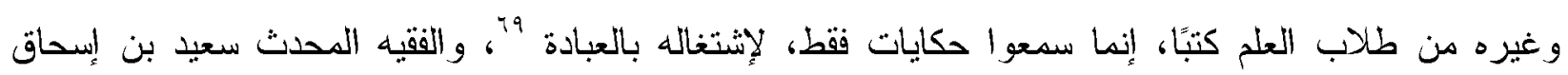

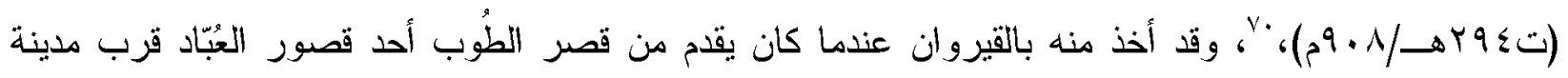

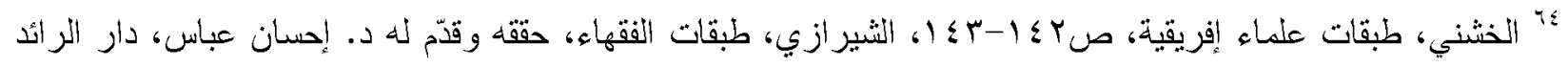

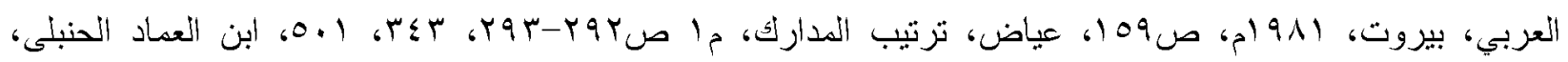
شذرات الذهب، دار الآفاق الجديدة، بيروت، بدون تاريخ، جY ص.r.r.

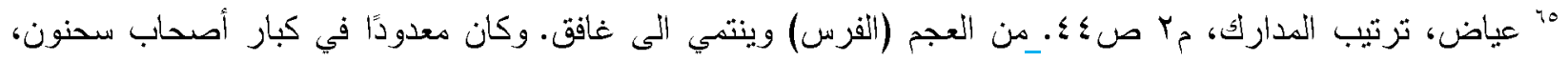

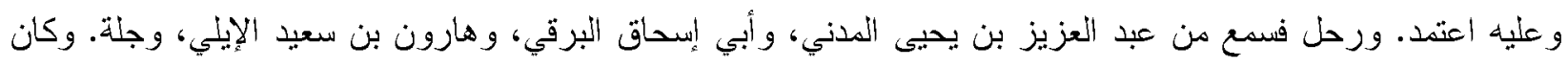

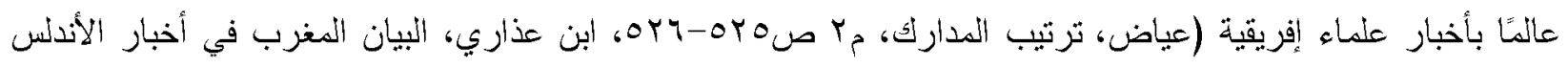

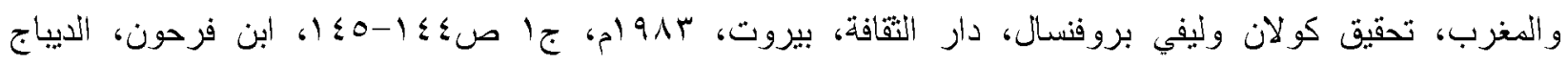

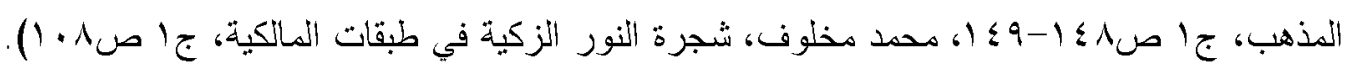

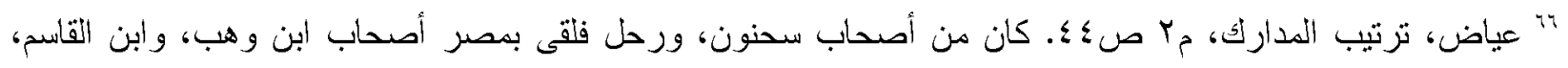

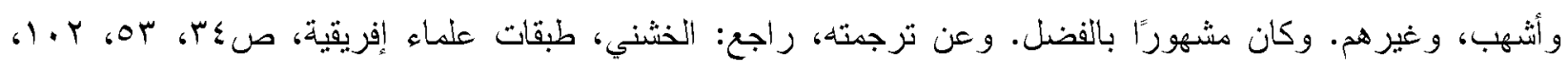

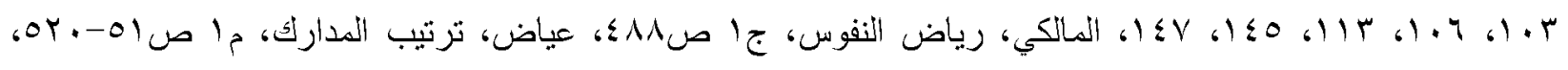

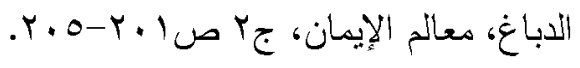

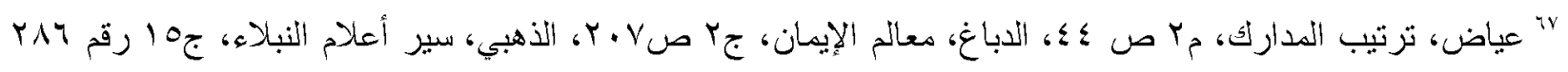

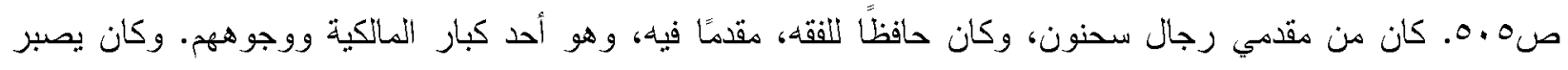

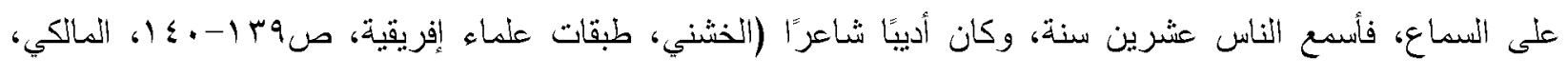

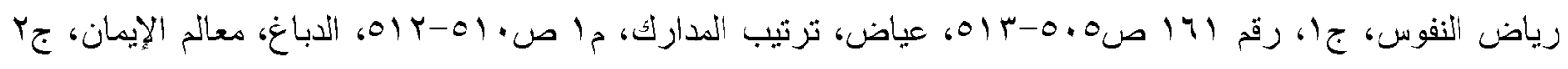
ص م.r

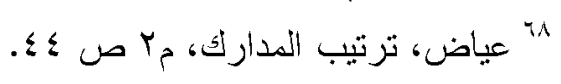

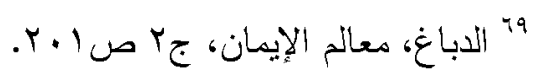

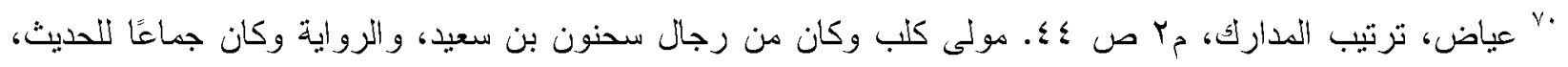

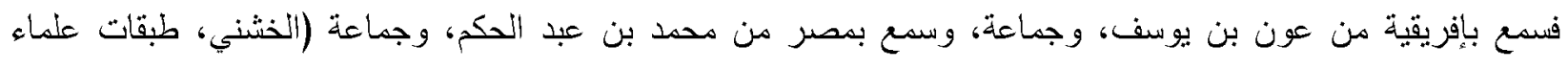


سوسة " فيأثيه الناس فبِمعون منه " "ل، وسمع ابن الحَجَّامِ أيضًا: من محمد بن مسكين أخي عبسى بن مسكين

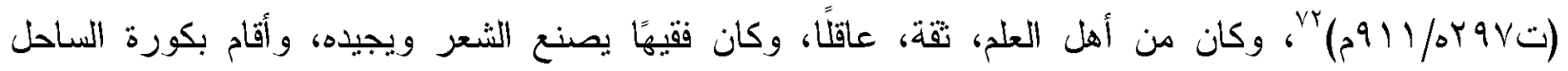

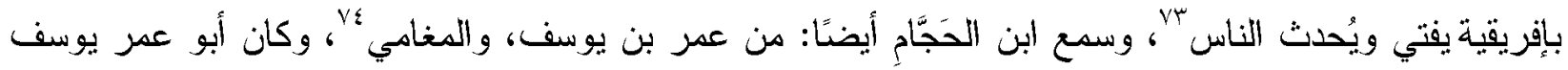

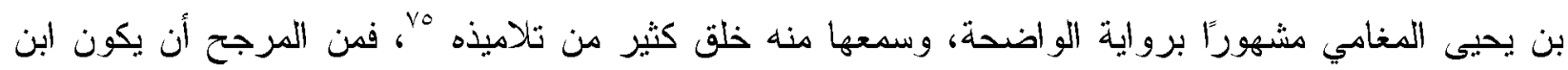

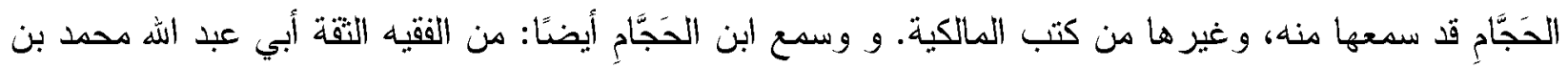

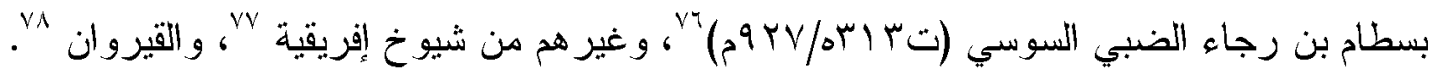

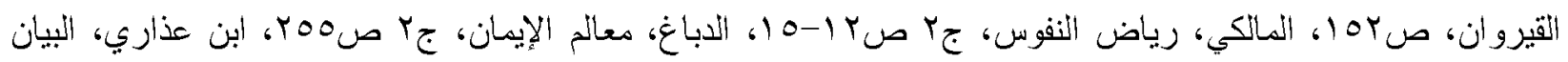

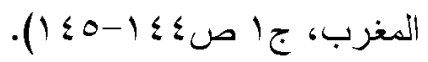
" وكان ساكنًا بقصر الطوب يقيم به شهورًا، ثم يقدم إلى القيروان فيقيم شهورًا، فيكثر الناس للنسماع عليه (المالكي، رياض

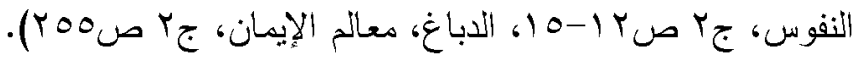

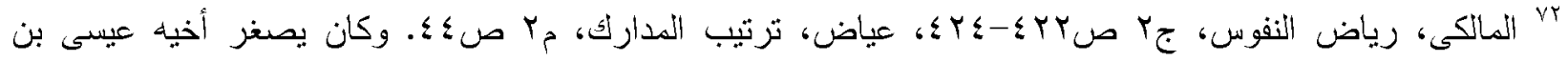

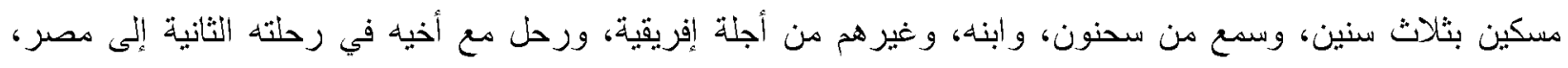

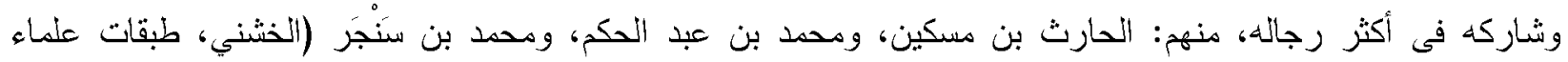

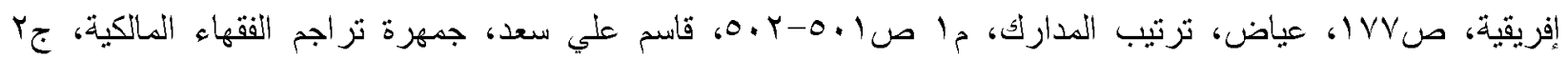
ص ص

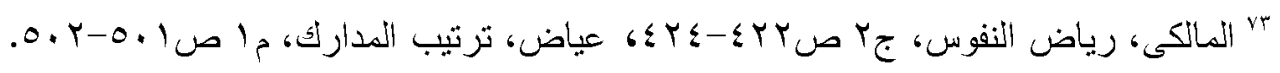

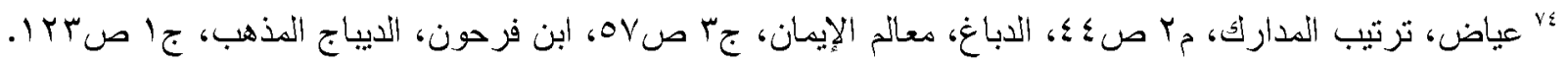

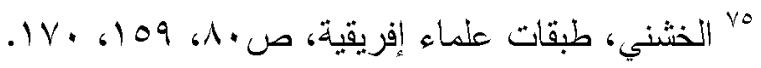

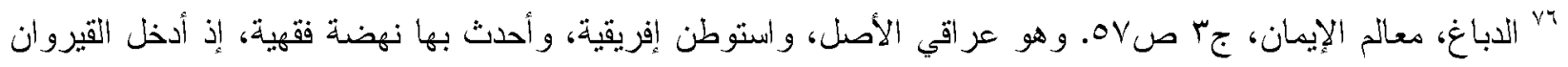

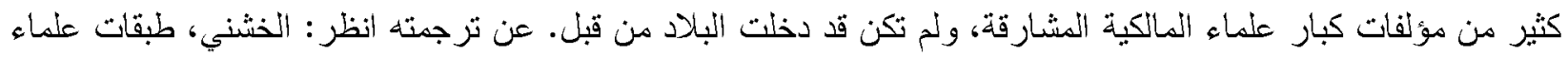

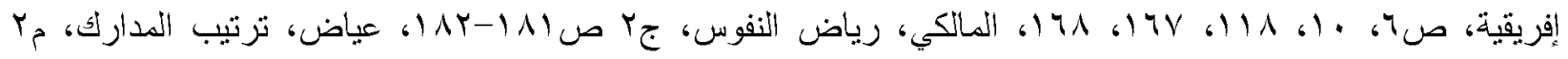

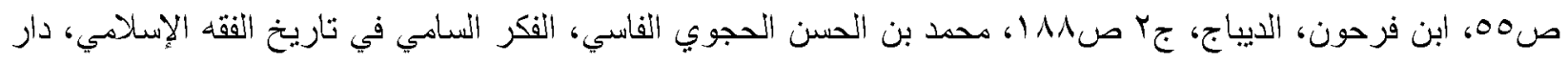

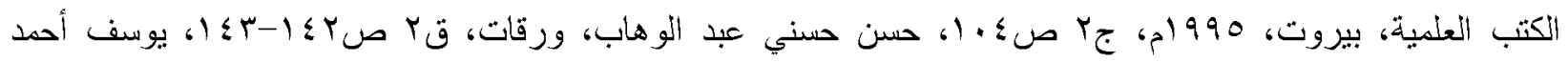

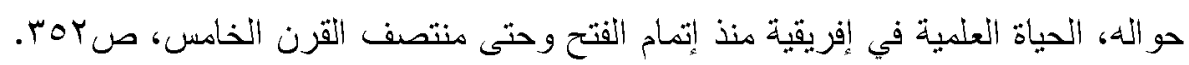

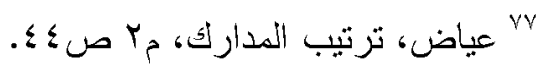

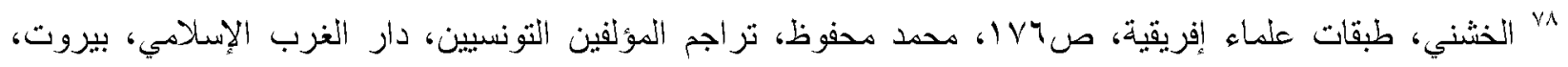

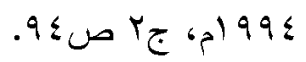




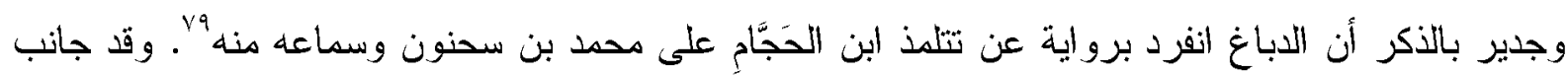

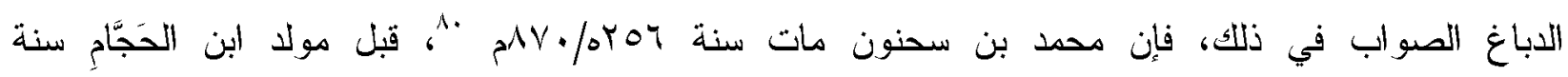

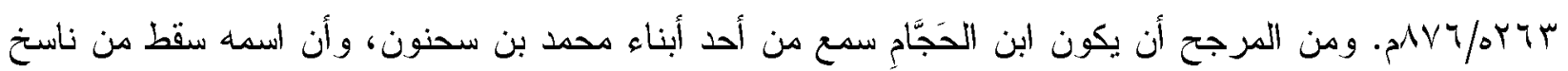
كتاب معالم الإيمان. وكان لمحمد بن سحنون عدد من الأبناء النجباء، منهم: أبو سعيد محمد بن محمد بن سحنون

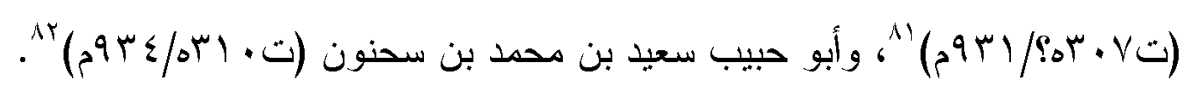

وتتلمذ ابن الحَجَّامِ أيضًا على بعض العلماء الأندلسيين الذين نزلوا بإفريقية، وبعض الذين لقيهر في مراكز

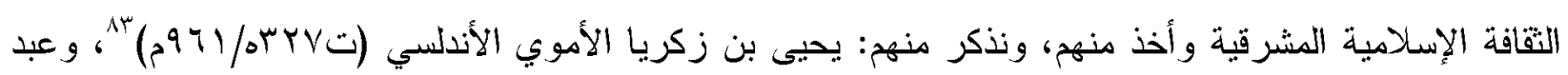

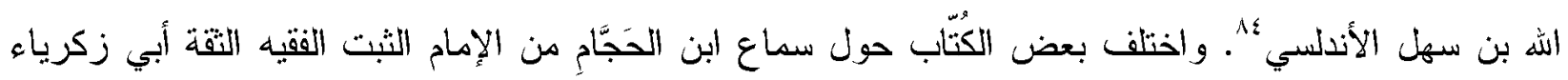

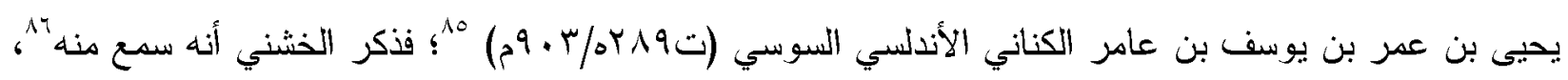

$$
\text { Pa }
$$

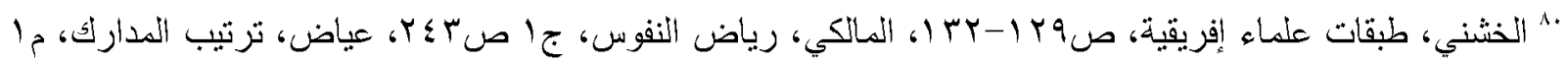

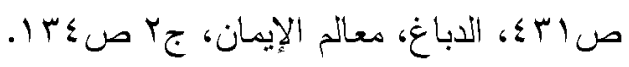

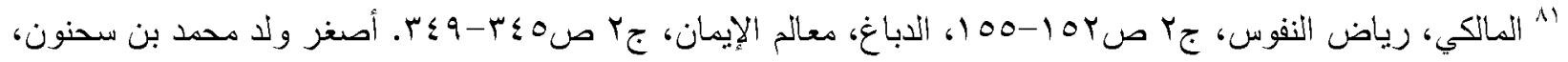

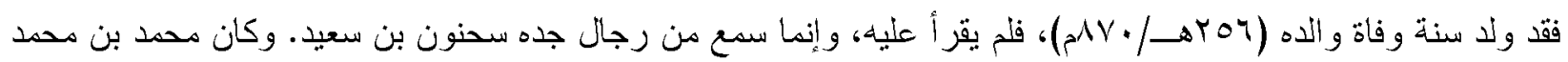

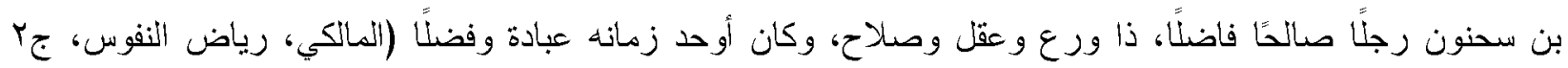

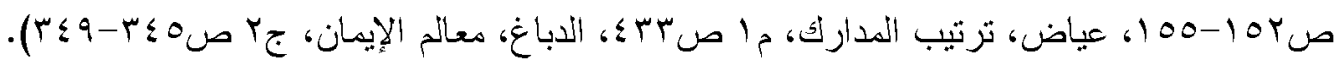

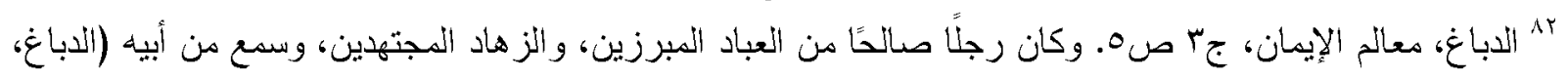

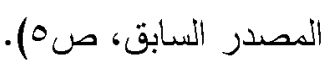

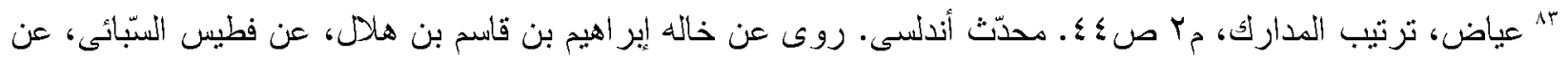

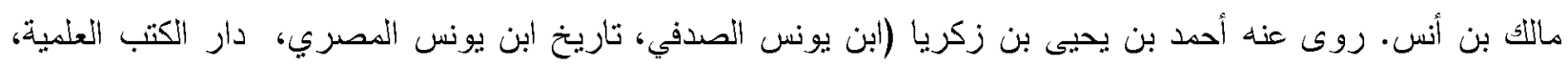

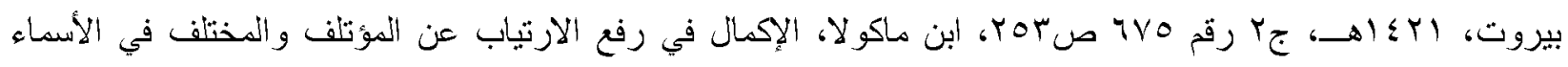

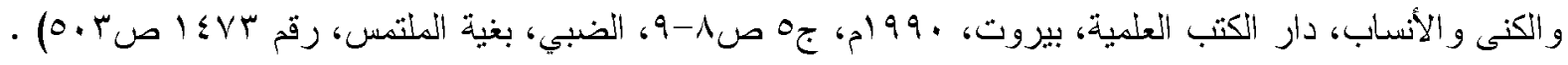

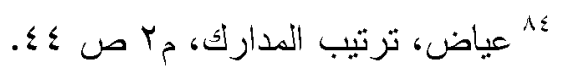

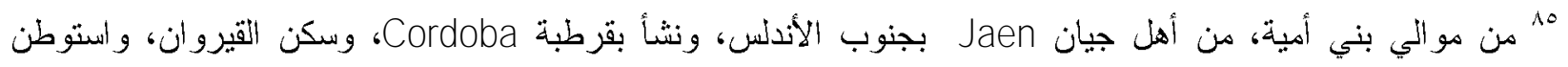

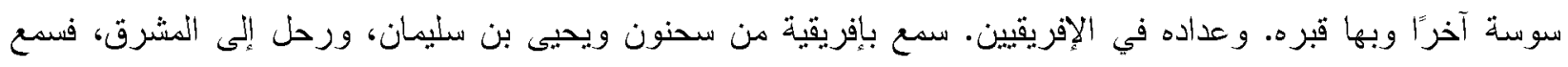

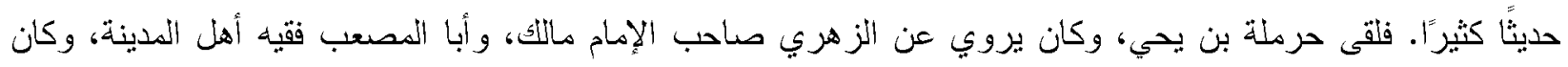

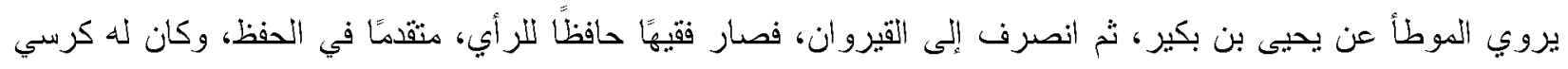


وذكر بعض العماء أنه لم بدرك يحيي بن عمر ، فكان أبو الحسن القابسي تلميذ ابن الحََّّامِ يؤكد لمن ذكر ذلك أن

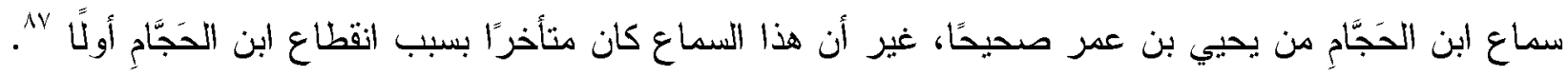
ونستدل من الروايات على صحة سماع ابن الحَجَّامِ من يحيى بن عمر، فقد تأثر بمنهجه العلمي وعلاقته بتلاميذه

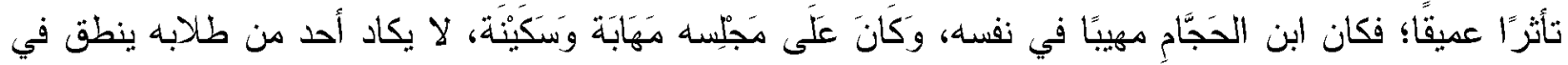

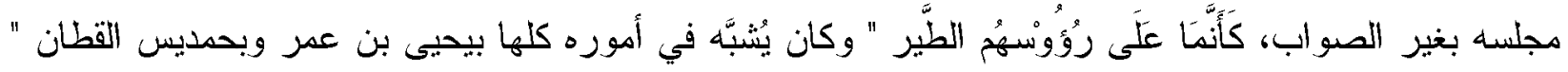

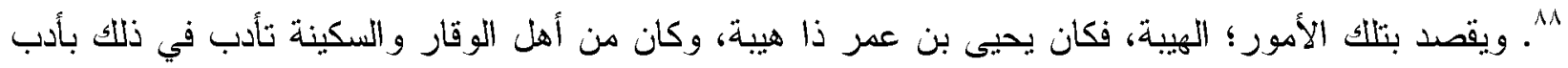
مالك"19. وكان حمديس القطان شُيدًا في مذاهب أهل السنة، وكان ذا غلو عظيم في النهي على من ينحرف عن طريقة أهلها، لا يسلم على أحد منهم، ومجانبًا لأهل الأهو اء". ومن المرجح أن ابن الحجام قد اقتدى أيضًا بشيخه

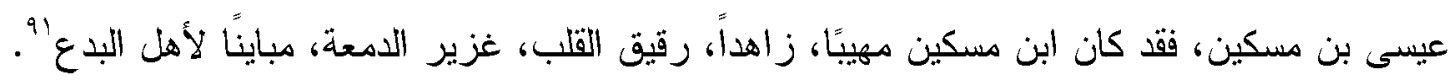

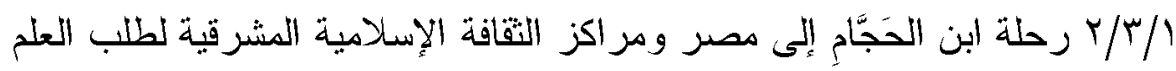

رحل ابن الحَجَّمِ عن بلده، لطلب الفقه و الحديث، فسمع جلة من علماء المالكية بمصر، وجدة، ومكة، وبغيرها

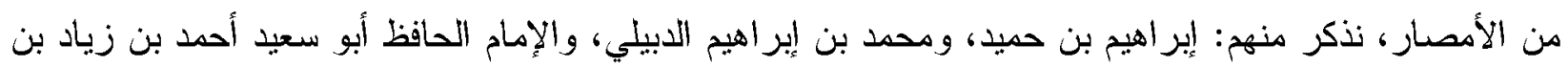

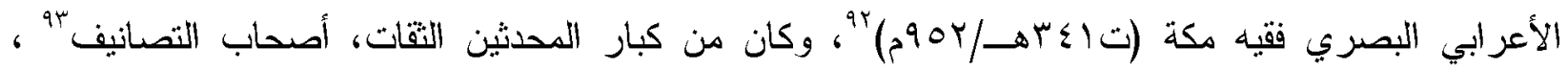

في مسجدها الجامع، فكان يجلس عليه ويسمع الناس. وتفقه عليه خلق كثير ، وإليه كانت الرحلة في وقته، وقد صنف كتبًا كثيرة في الفقه والآثار، منها: أحكام السوق، واختصار المستخرجة المسمى بالمنتخبة، وغيرها. عن ترجمته، راجع:

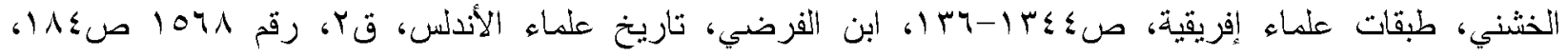

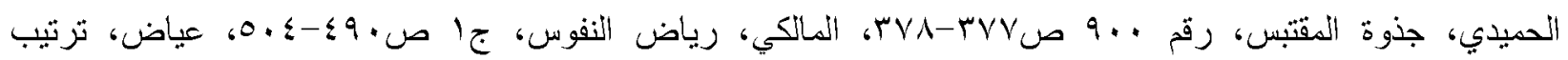

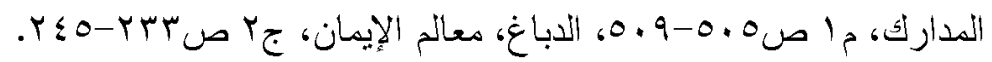

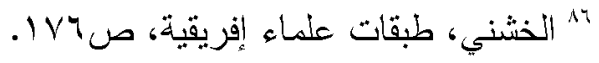

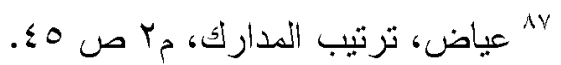

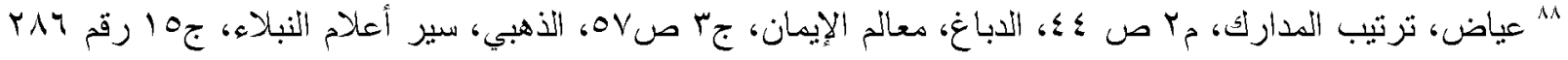

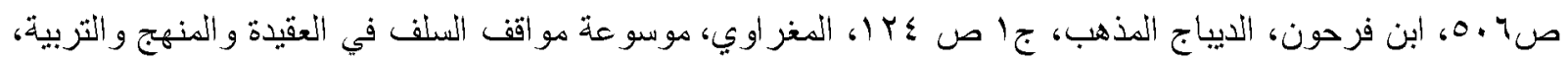

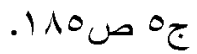

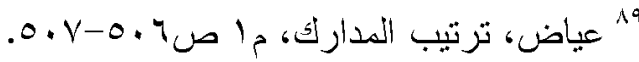

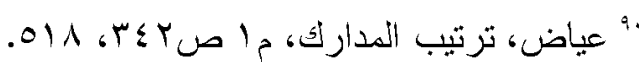

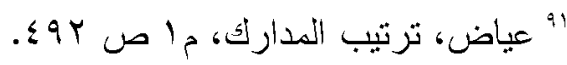

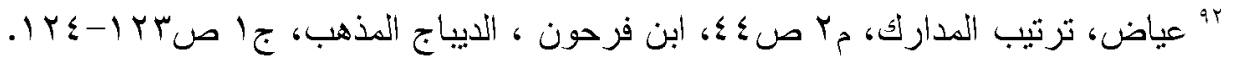


وسمع أيضًا من حسن بن علي بن عبد الله بن عبد الرحمن بن أبي مطر العامري قاضي مصر ؛و؛، وعبد الله بن

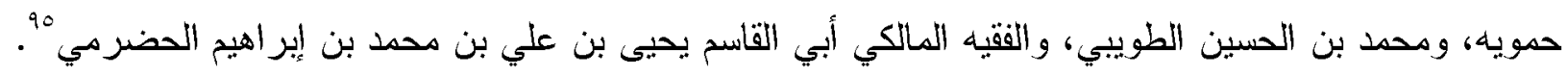

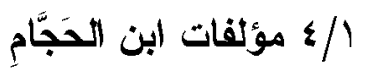

أفادت المصادر أن ابن الحَجَّام الفقبه القروي كان كثير التصنيف في أنواع العلوم بو، وألف كتبًا كثيرة، منها: كتاب المواقيت ومعرفة النجوم والأزمان Vو. وللأسف لم تحتفظ المصادر بأسماء مصنفاته غير ذلك الكتاب. ونستدل من رواية انفرد بها القاضي عياض أن ابن الحَجَّمِ قد اعتمد على مصنفِ للإمام مالك كان قد ألفه في "

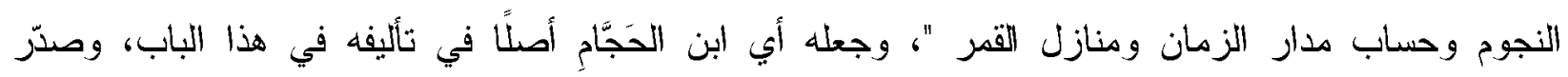
بفصوله 1/ / مكانته العلمية وأقوال العلماء فيه وثناؤهم عليه وفضائله

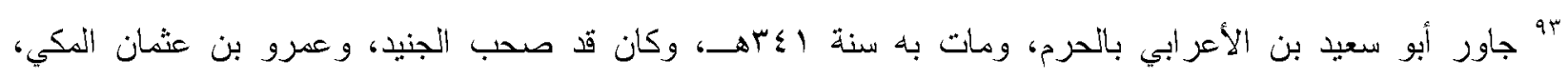

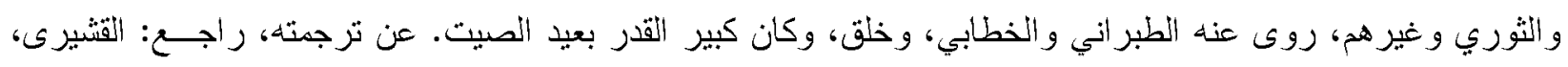

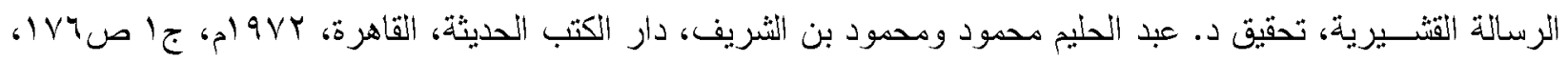
الذهبي، تذكرة الحفاظ، مَّ، جr صrAOr-10r، وله أيضًا: المعين في طبقات المحدثين، تحقيق همام عبد الرحيم سعيد،

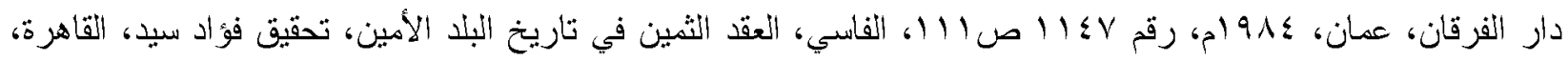

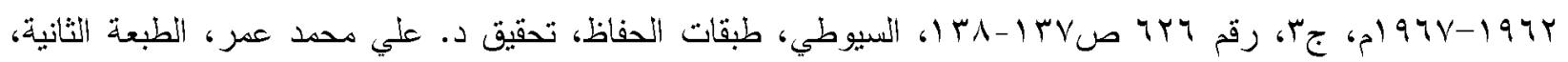

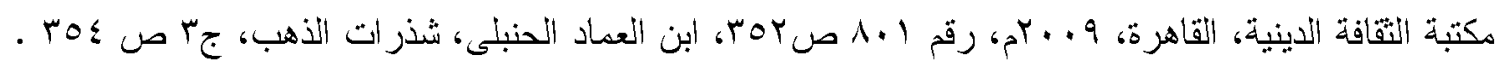

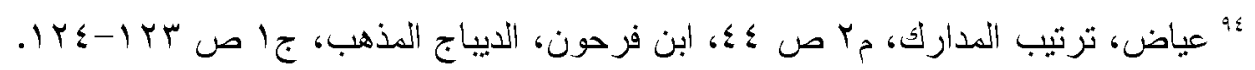

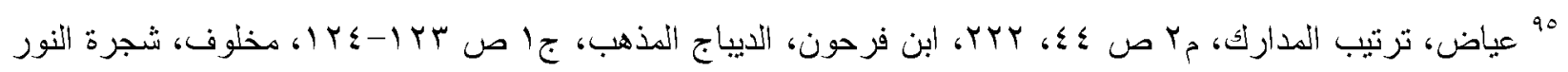

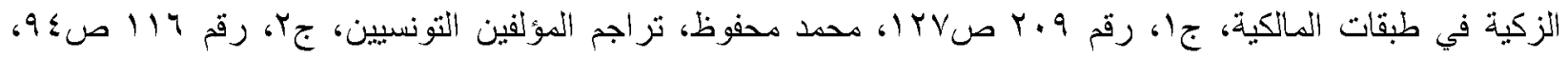

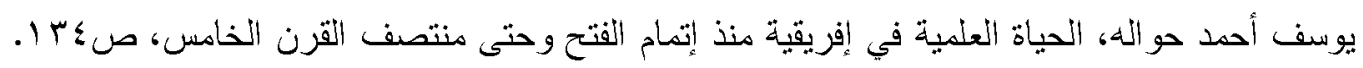

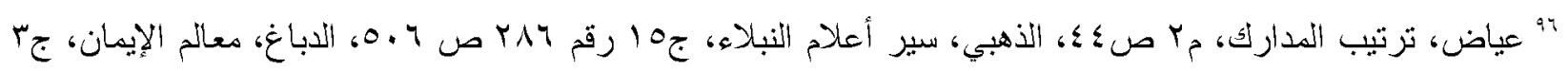
ص1.01

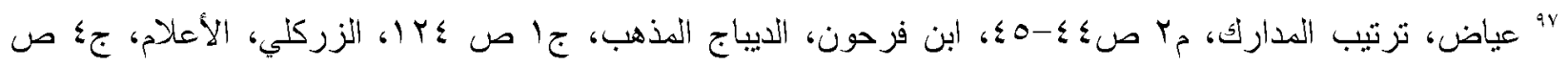

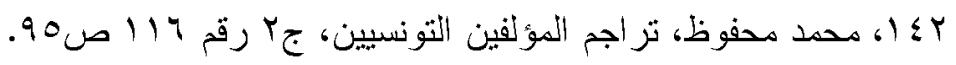

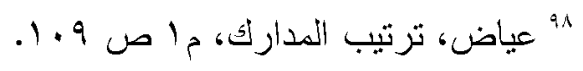


كان الفقبه أبو محمد عبد الله بن مسرور ابن الحَبَّم كما ذكر المالكي أحد الأئمة "99؛ وقال عنه الذهبي: " إِمَامٌ

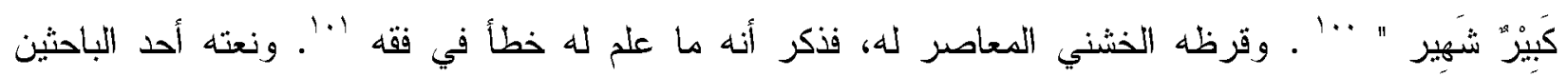

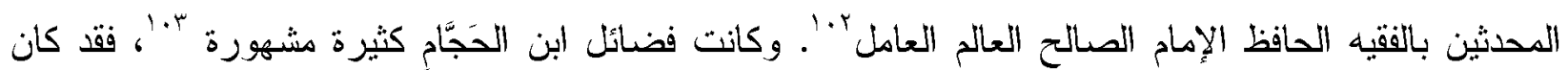

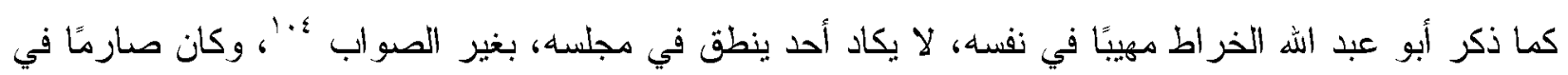

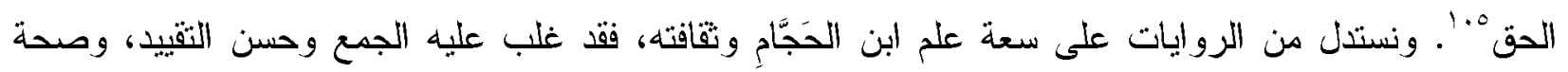

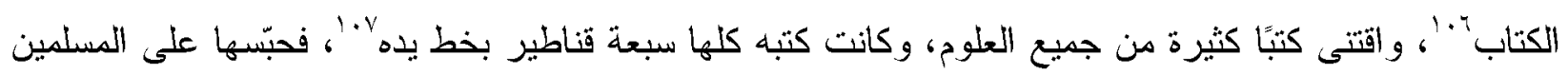

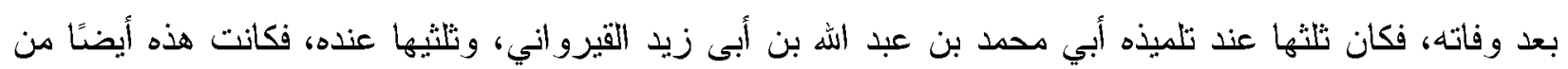

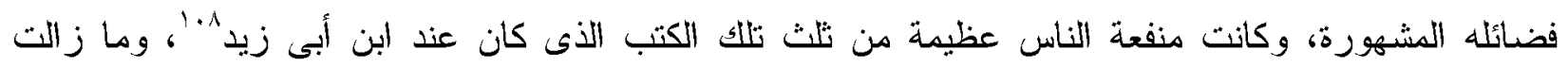

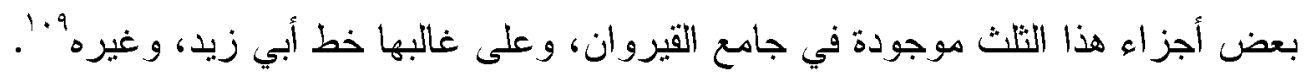
(r) تلاميذه القيروانيين والأندلسيين

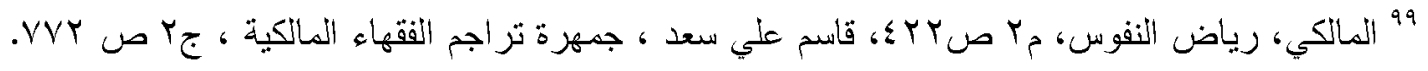

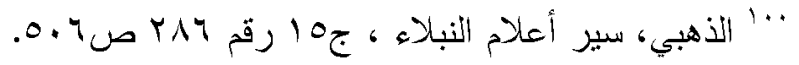

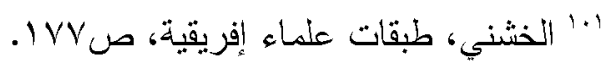

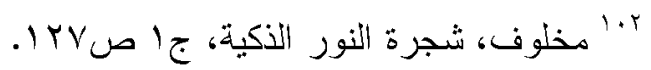

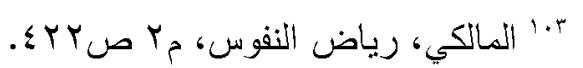

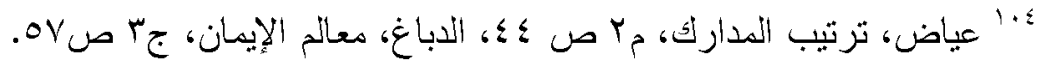

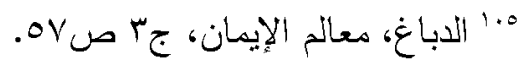

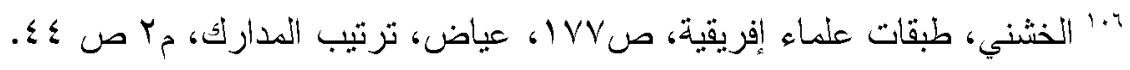

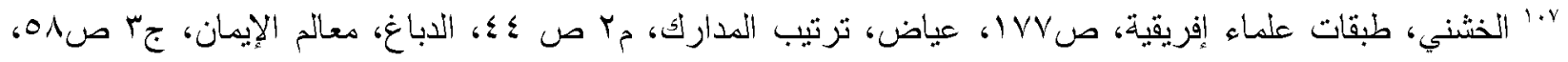

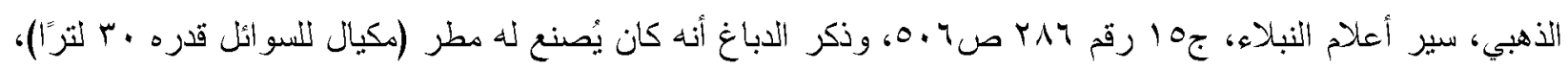

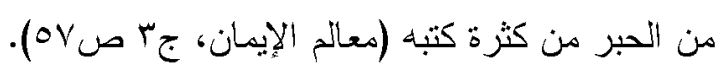

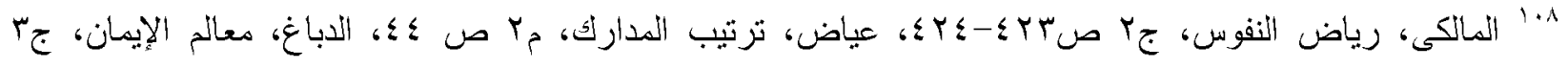

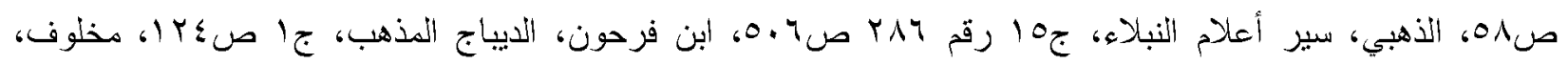

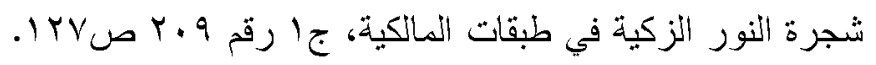

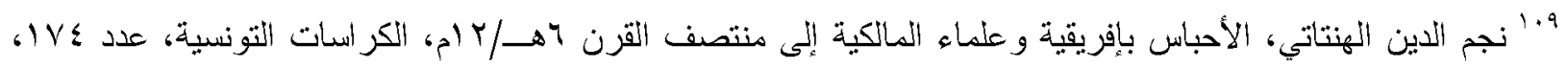

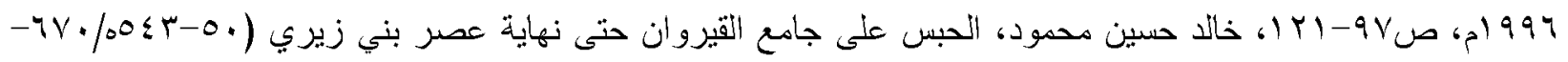

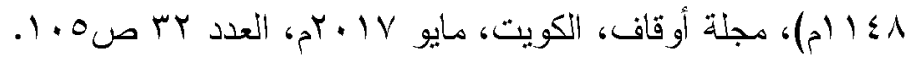


بعد أن اكتمل تحصيل ابن الحَجَّامِ بمر اكز الثقافة الإسلامية التي رحل إليها، عاد إلى القبروان، فجلس للارس،

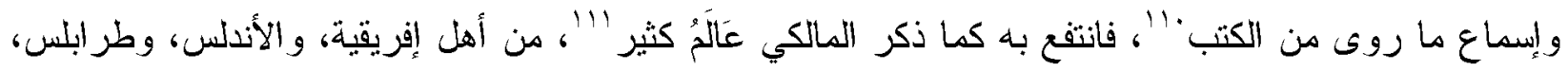

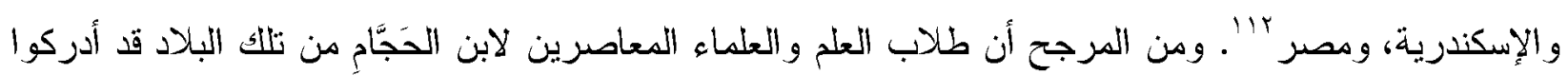
قيمته العلمية وعرفو اله أستاذيته، فتكاثروا عليه وتحلقو ا حوله ينهلون من فيض علمه، فسمعوا منه وكتبوا عنه. ولا ريب أن حصر تلاميذ ابن الحَجَّام متعذر جدًا. وسنذكر فيما يلى بعض مشاهيرهم الذين تخرجوا على يديه: ا 1/ ا تلاميذه القيرو انيين

انتفع بابن الحَجَّام خلق كثير من طلاب العلم المغاربة. وأمدتنا المصادر بأسماء بعضهه، ومن أبرزهم: الفقيه

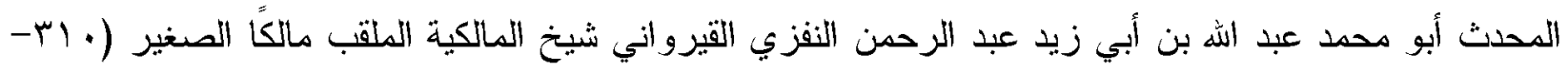

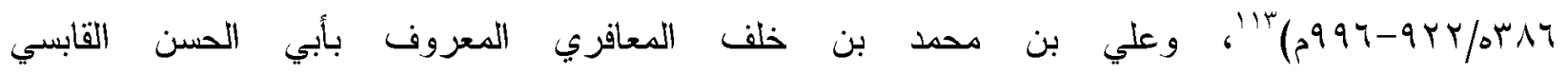

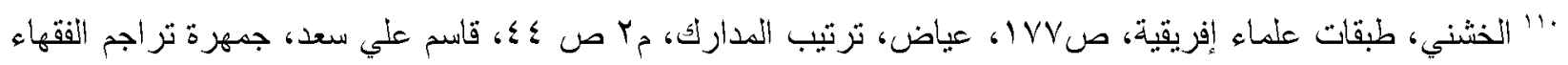

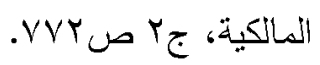

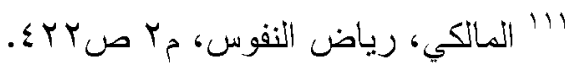

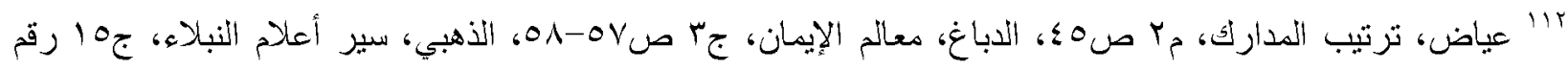

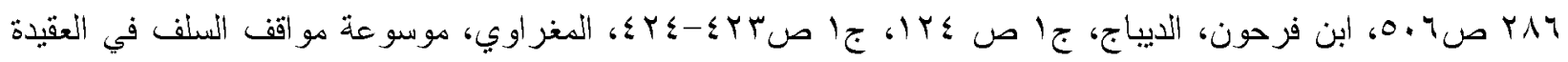

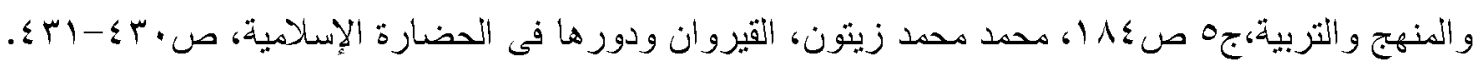

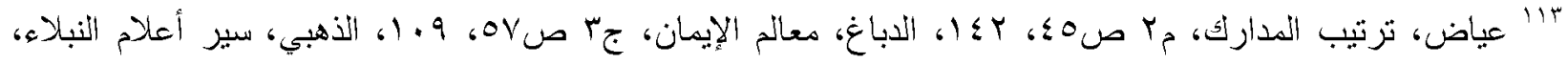

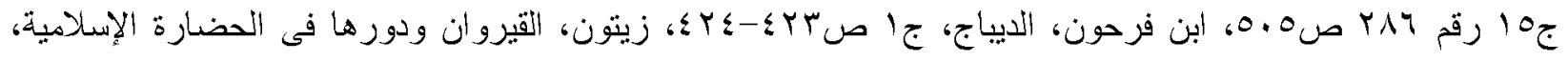

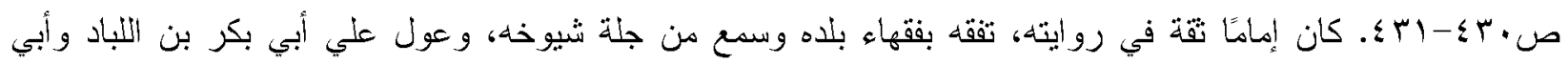

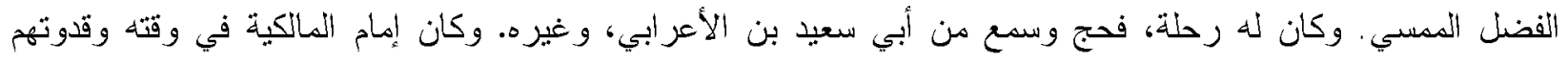

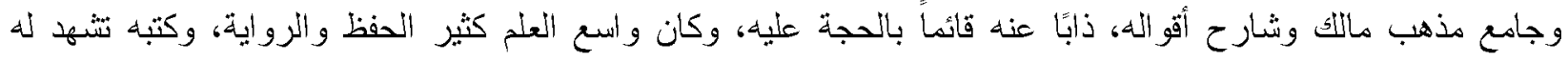
بذللك، ومنها: النوادر و الزيادات على المدونة، ومختصر المدونة، وعول عليهما أهل المغرب في التنقفه، وكتاب الذب عن الته

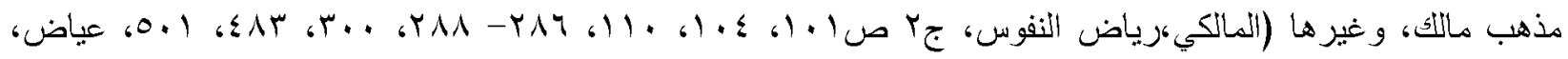

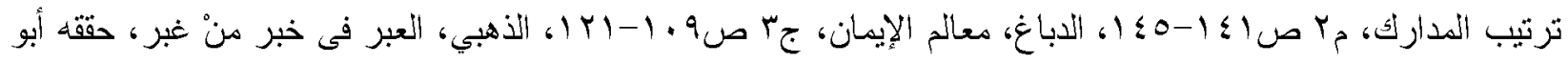

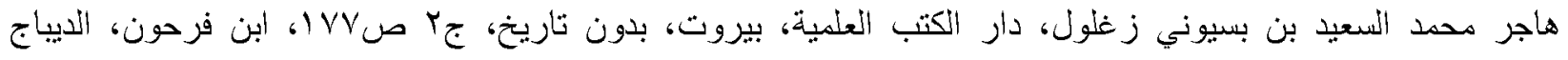

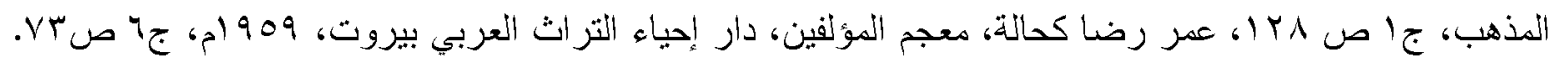




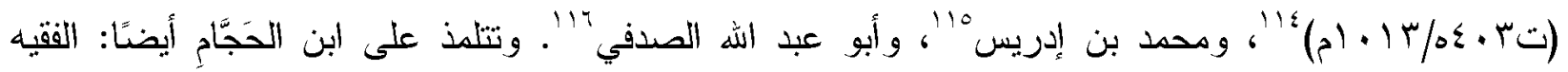

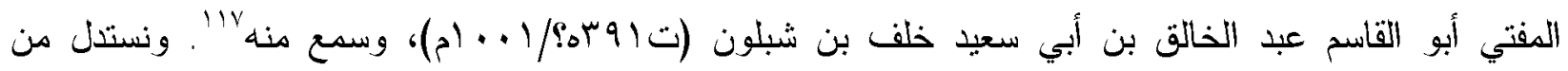

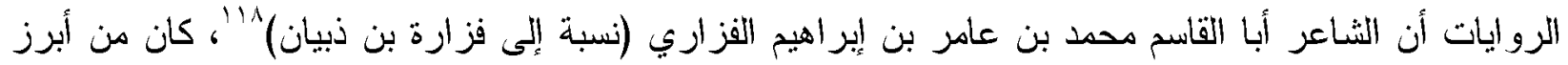

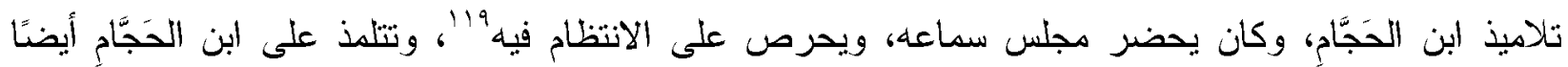
علي بن محمد الربعي، وروى عنه ‘r'. وقد حدّث علي بن محمد الربعي، قال : حدثنا أبو محمد بن مسرور، قال: حدثا عيسى بن مسكين، عن محمد بن عبد الله بن سَنْجَر، عن حجاج بن مِنهال، عن حماد، عن عاصم بن بهالة،

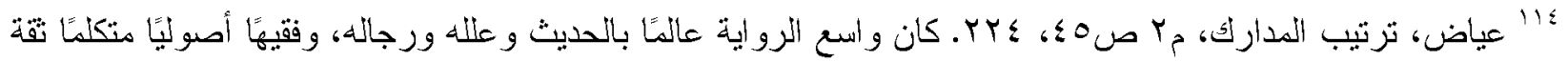
صدالحًا. وكان أعمى وهو هع ذلك من أصح الناس كتبًا وأجودهم ضبطاً وتقيبدًا بضبط كتبه بين بديه ثقات أصدابه، سمع هن رجال إفريقية، ورحل سنة به بهـ، فحج وسمع من علماء أجلاء، وهو أول من أدخل رواية البخاري إفريقية، وله

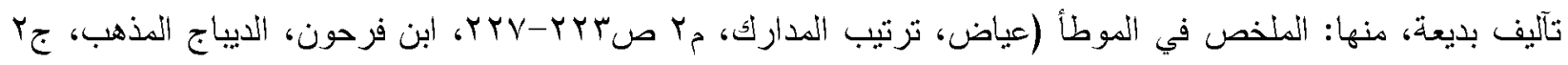

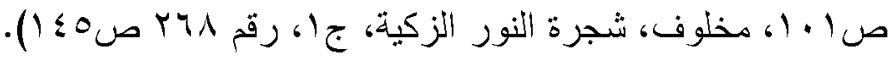

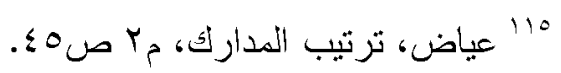

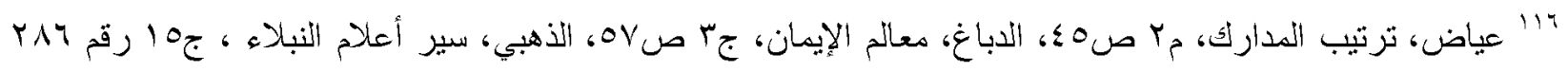

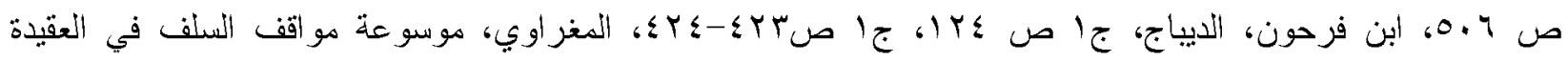

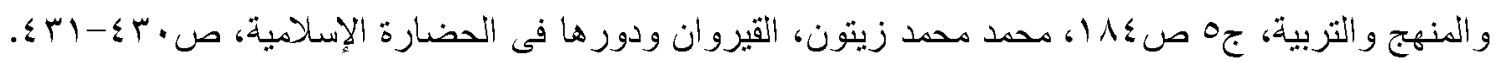

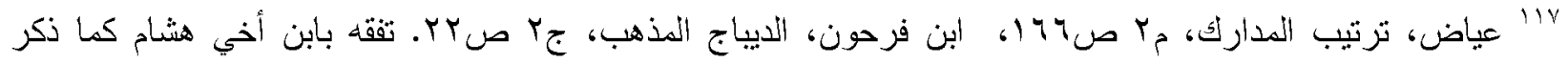
الثبير ازي. وكان الاعتماد عليه بالقيروان في الفتوى، والتدريس بعد أبي محمد بن أبي زيد. وألف كتاب المقصد، أربعين

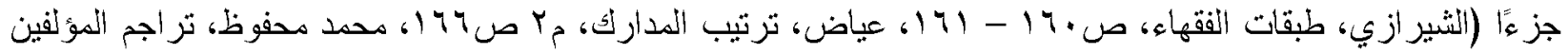

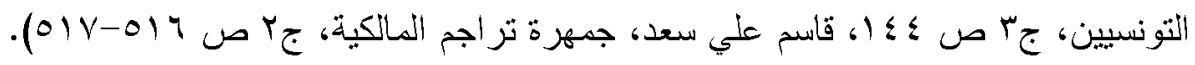

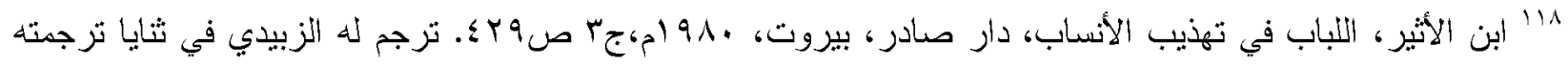
لأبيه الثـاعر اللغوي عامر بن إبراهيم الفزاري، فذكر أن أبا القاسم كان بصبرًا بالأداب (طبقات النحويين و اللغويين، تحقيق

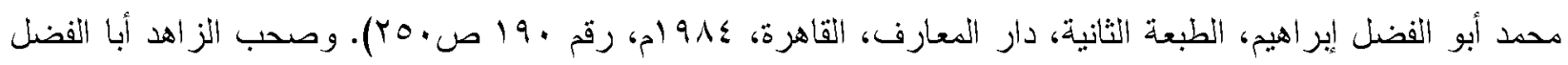

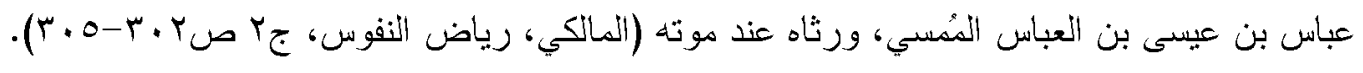

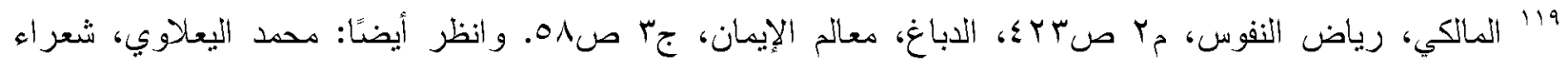

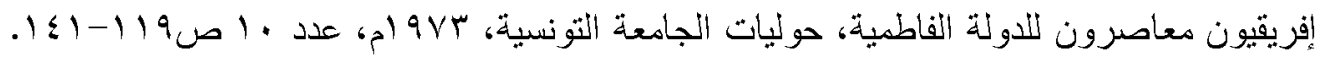

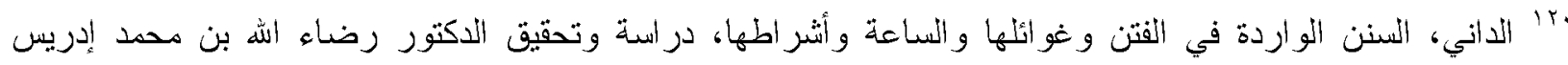

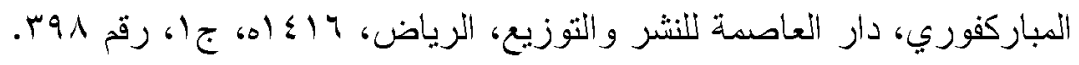


عن الثعبي، أن رسول الله صلى الله عليه وسلم، قال : " من اقتراب الساعة أن يُرى الهلال ابن ليلة كأنه ابن ليتلين

وقد أجاز ابن الحَجَّام جميع تلاميذه رواية كتبه، ومسموعاتهبr|. غير أنه عاد ونبذ جماعة من تلاميذه

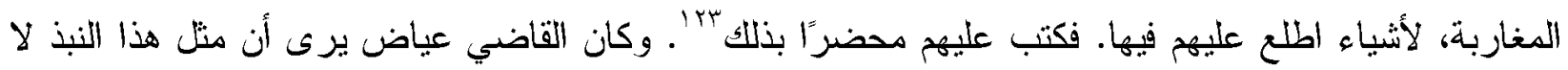

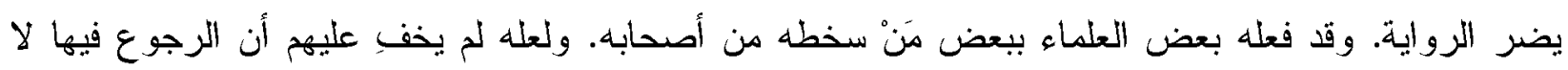
يصح، لكنه كالردع و التجريح لهز كُبا.

\section{r/r الأندلسيون تلاميذ ابن الحَجَّامِ القيرواني}

أكد كثبر من الكُاب المسلمين على ضرورة الرحلة في طلب العلم ولقاء المشيخة، واعتبروها " مزيد كمال

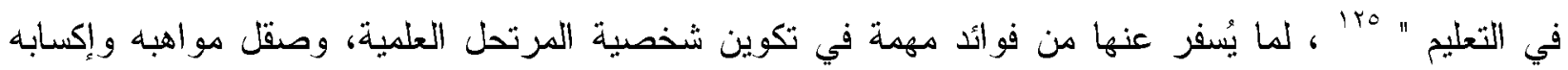

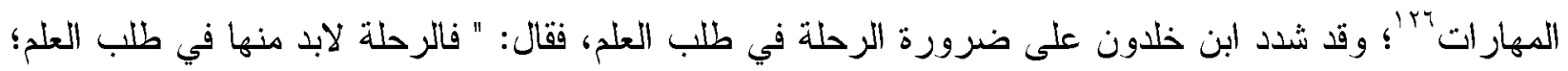

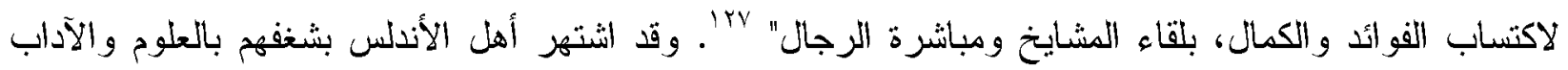

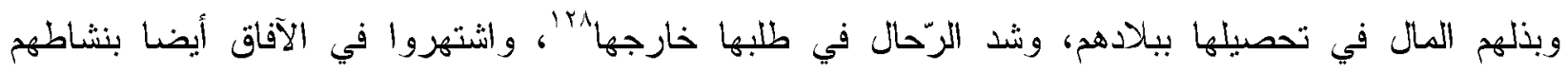
التجارى الواسع داخل بلادهم وخارجها؛ ولذلك نعتهم الرّحالة المقسى بتقير العلم وأهله، وكثرة التجارات

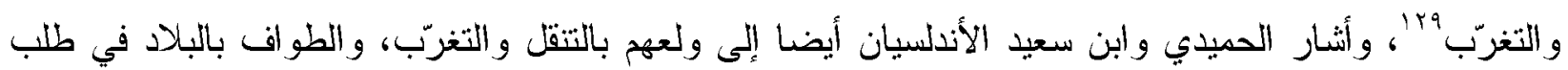

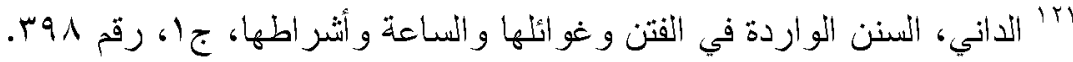

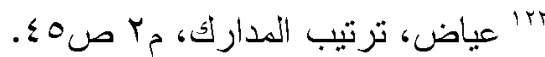

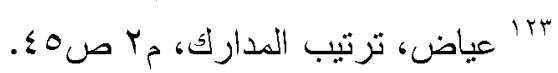

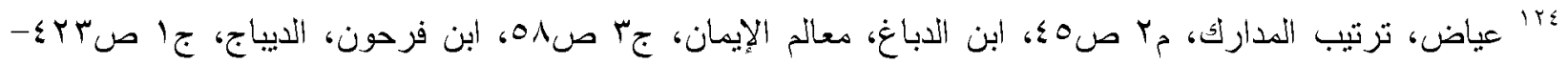

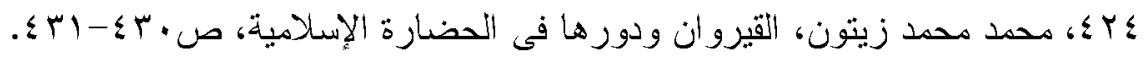

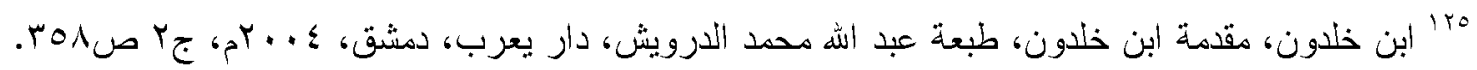

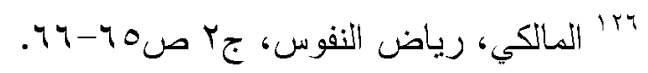

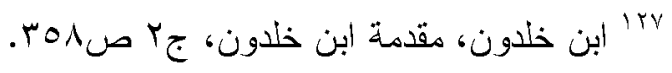

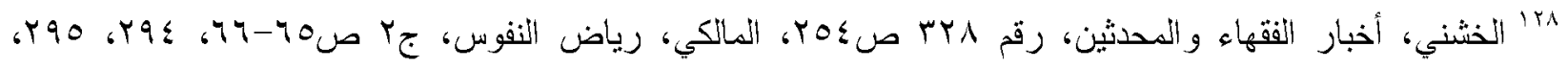

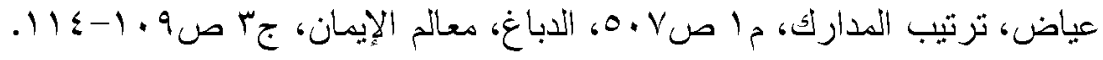
9r9 أحسن التقاسيم في معرفة الأقاليم، طبعة د. محمد مخزوم، دار إحباء التزراث العربي، بيروت، 9 ام، ص190. 


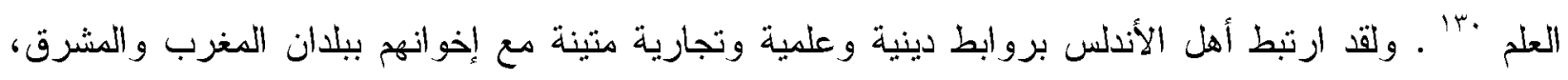

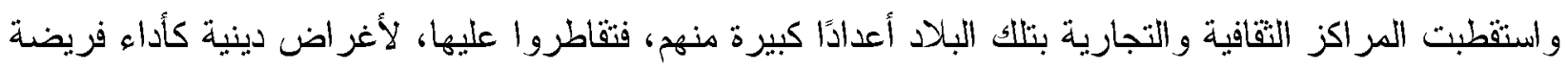
الحج ومجاورة الحرمين الشريفين، و لأغر اض علمية، أو كما ذكر ابن حيان القرطبي " لقضاء الفرض، و اقتباس

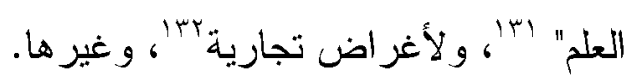

وقد جذبت شهرة ابن الحَجَّمِ ومكانته العلمية كثير من طلاب العلم الأندلسيين، فحرصوا على السماع منه أثناء توجههم إلى مراكز الثقافة الإسلامية المشرقية، لطلب العلم، ونذكر منهخ: أبو القاسم مسلمة بن القاسم بن إبراهيم

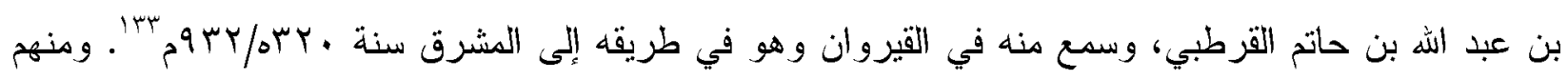

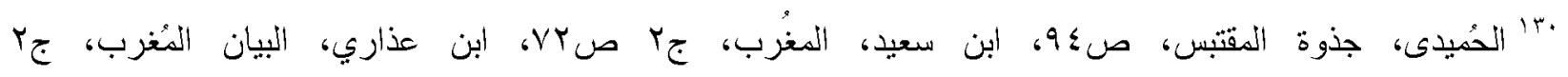
ص.0. T. T. T

Makki, Ensayo sobre las aportaciones orientales en la Espana Musulmana, pp. 9-11.

آ"ابن حيان، السفر الثانى من كتاب المقتبس، حققه وقدّم له و علق عليه د. محمود على مكى، الطبعة الأولى، مركز الملكا

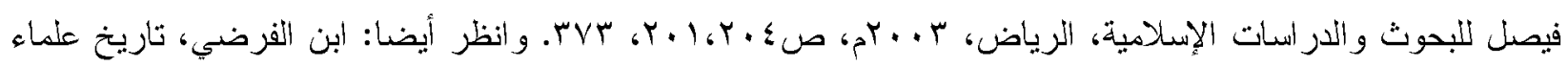

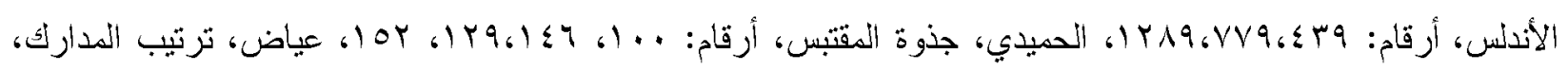
Makki, Ibid, pp.5- 11.

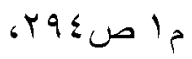

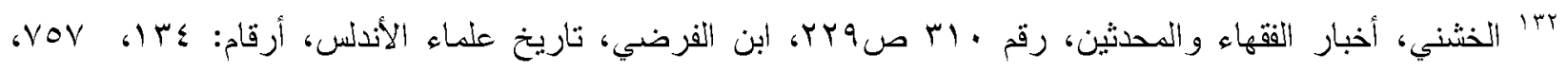

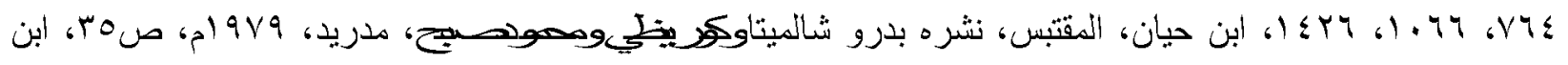

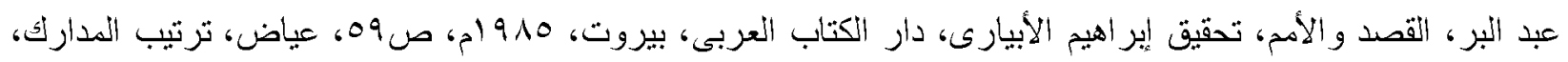

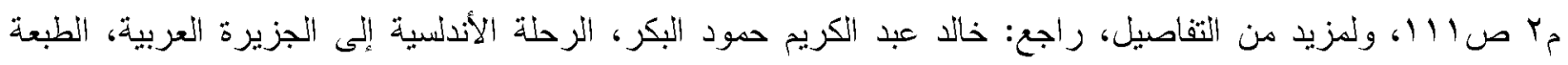
Makki, Ibid, pp.11- 17.

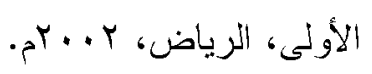

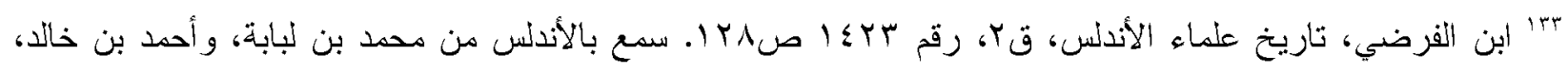

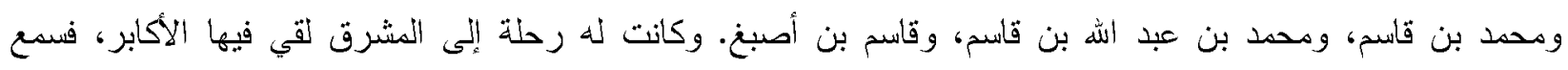

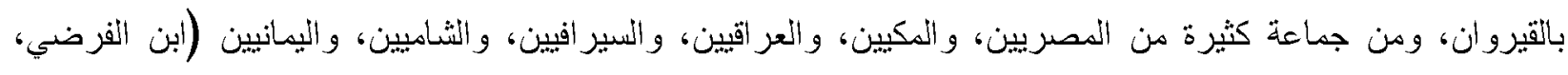

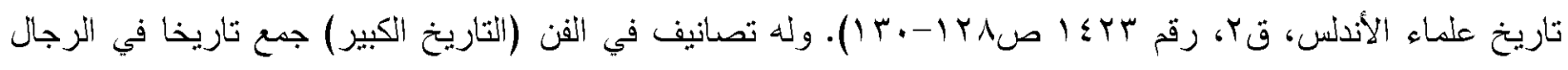

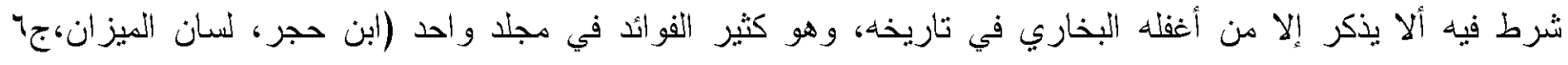




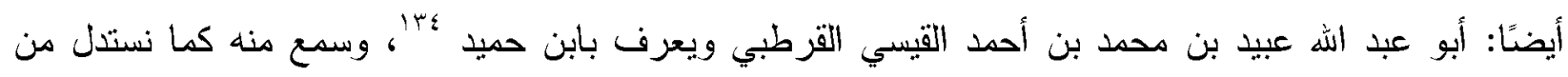

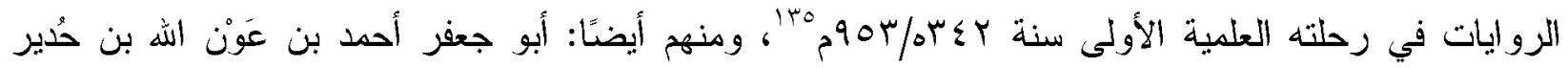

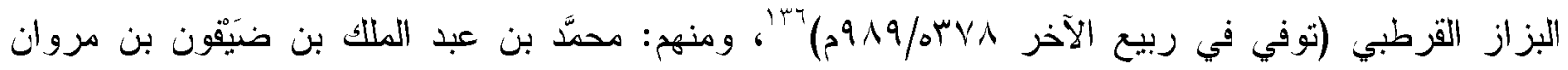

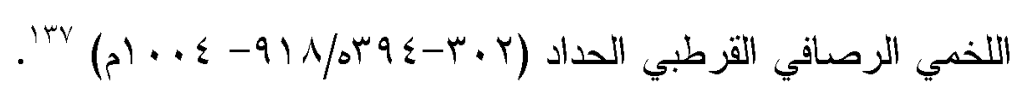

(r) منهج ابن الحَجَّامِ في رواية الحديث ووجوه استفادة تلاميذه منه

وكان ابن الحَبَّمِ متفرغًا طوال حياته للعلم؛ طلبًا، ورواية، وتدوينًا، وقد شغف بذلك شغفًا شديدًا ملك عليه

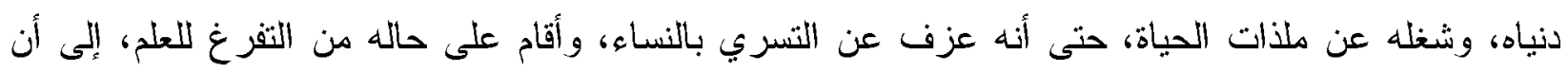

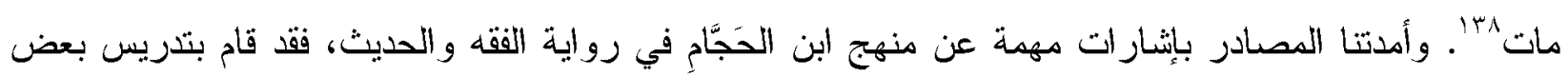

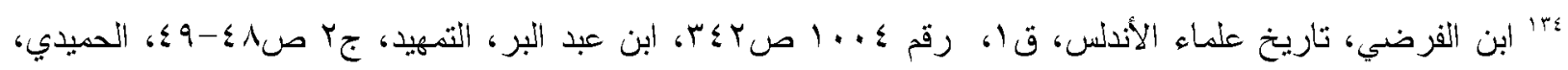

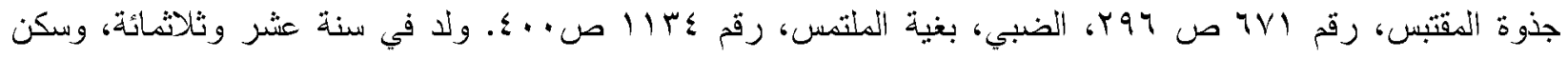

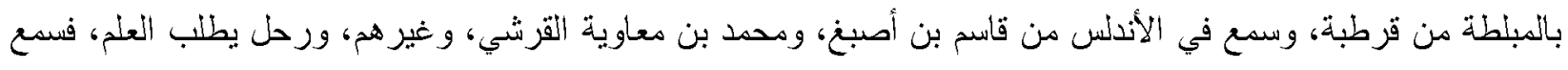

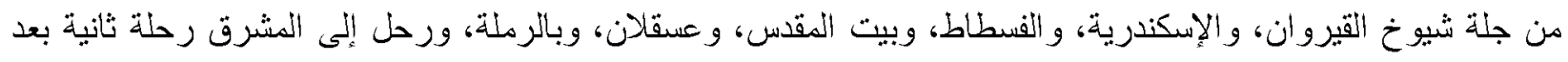

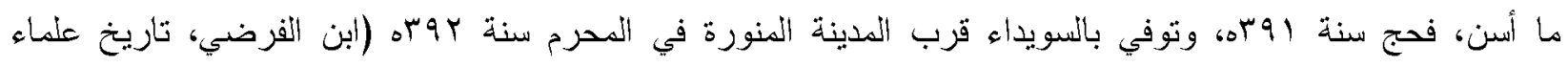

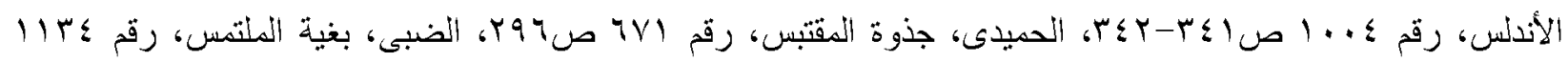

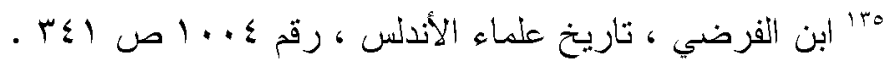

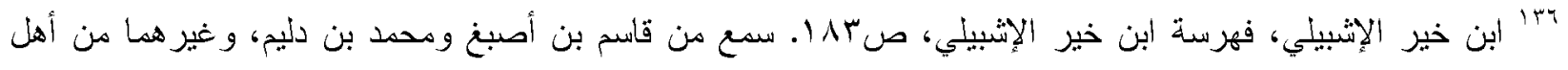
قرطبة، ورحل فسمع بمكة: من أبى سعيد بن الأعرابى وجماعة، وسمع بطرابلس الثام، ودمشق، ومصر ، وجماعة يكثر تعدادهم، وروى عنه أبو عمر الطلمنكى، والأمام ابن دَنيْن عبد الله بن عبد الرحمن الصدفي الطليطلي، وخلق (ابن

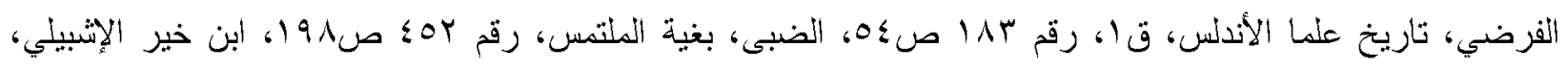

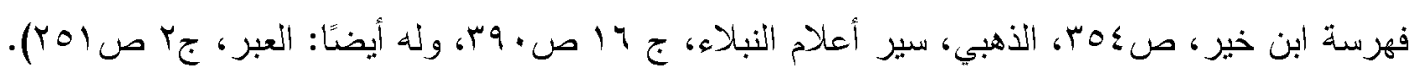

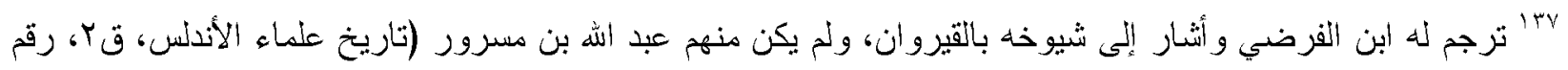
بوسا صو9 (1)، غير أنه عاد وذكر في موضع أخر من كتابه أن محمد بن عبد الملك بن ضيفون التقى ابن مسرور

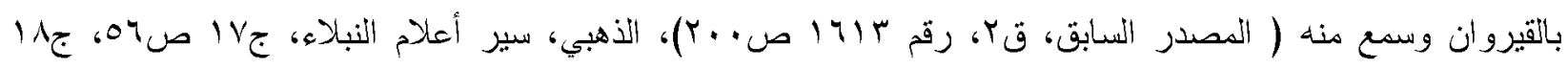

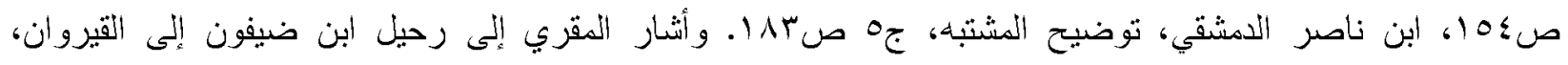

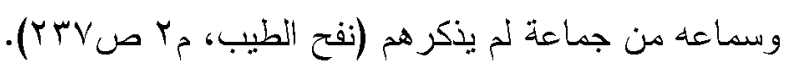

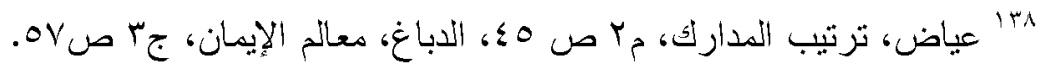


الكتب والأجزاء الحديثية لطلاب العلم القيرو انيين والقادمين إليها والمقيمين بها، وكان كغيره من كبار المحدثين يجلس لطلابه في حلقته، وفي بيته يُملى عليهم من حفظه، أو يستملى بعض تلاميذه النجباء، خاصة عندما تقدم به وهيه

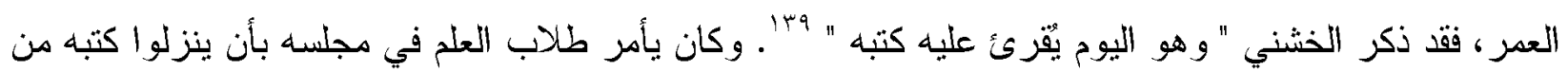

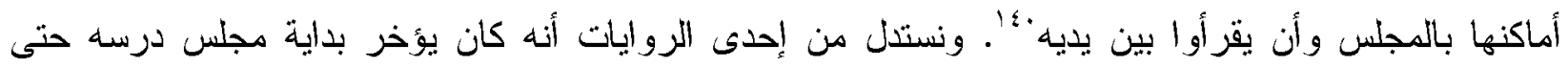

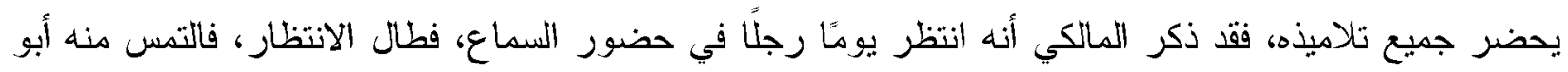
القاسم الفزاري الثاعر، وكان يحضر مجلس السماع، أن يبدأ الدرس دون انتظار طالب العلم المتأخر عن مجلس يلس

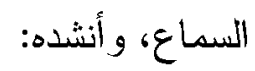

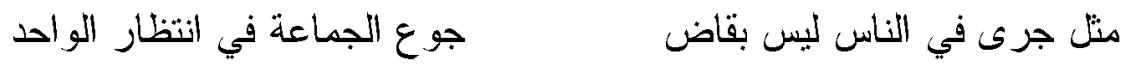

فأمز ابن الحجام تلاميذه الحاضرين أن يجززوا أور اقهم، وأن يبدأوا القراهة '§؟. وبطبيعة الحال كان عدد المجالس التي استغرقتها رواية ابن الحَجَّام لبعض الكتب والأجزاء الحديثية يتوقف على حجم هذه الكتب، وطبيعة المجالس؛

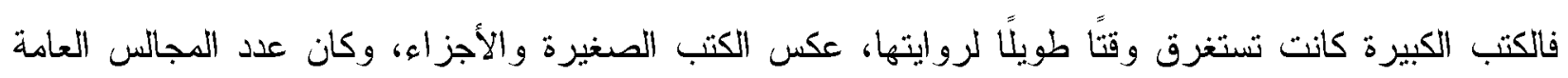
يختلف بلا شك عن عدد المجالس الخاصة، وكان عدد المجالس العامة ومدتها يتوقف أيضًا على عدد التلاميذ الحاضرين ومقدرته على الفهز وسر عة الاستيعاب، ومدى إلتزامهخ بمو اعيدها كما رأينا. (؛) موقف ابن الحَجَامِ المعارض للمد الثثيعي في إفريقية وتأثر تلاميذه القيروانيين به كان أهل السنة بالقبروان في حالة شديدة من الاهتضام والتستر أيام الدولة الفاطمية " تجري عليهخ في كثرة

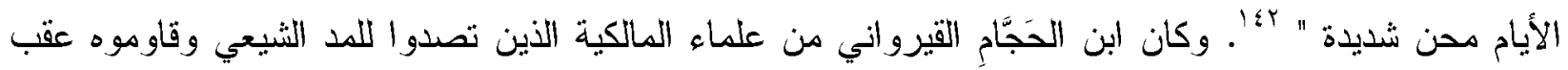

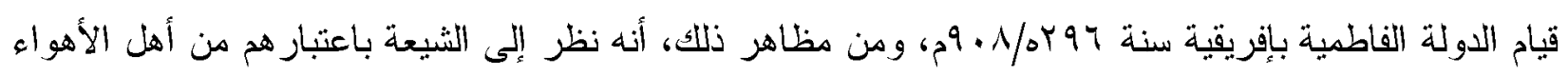

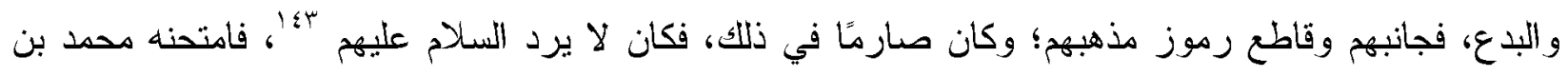

9"1 الخشني، طبقات علماء إفريقية، ص IVV.

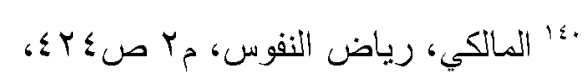

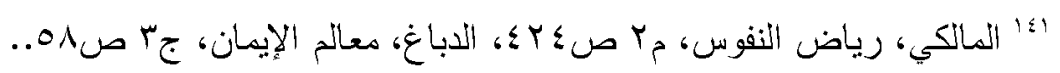

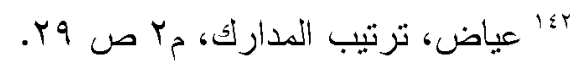

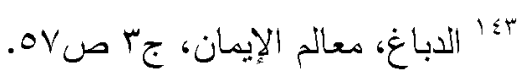


عمر المروذي القيرواني قاضي الثبعة بإفريقية؛؛ ، ونكبه مدة ثلاث سنوات وأراد قتله، فنجاه الله منه ه؛. وجدير بالذكر أن أبا عبد اله الثيعي كان قد عهد إلى محمد بن عمر المروذي بقضاء إفريقية، فتصلب وتكبر وتجبر،

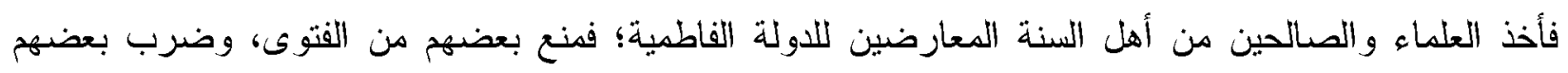

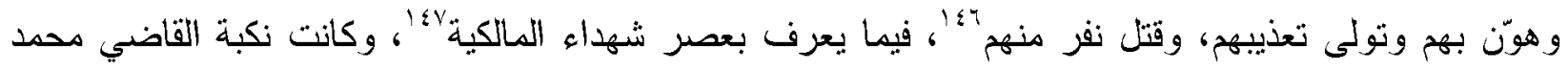

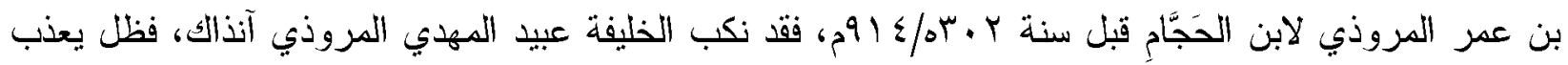

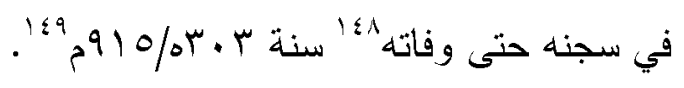

؛ءا أصله من مرو الروذ (مرو الصغرى)، ببلاد فارس، فنسب إليها. وكان معتقدًا لمذهب الثيعة معروفًا بذلك، فلما دخل

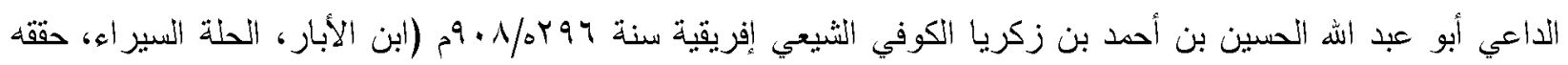

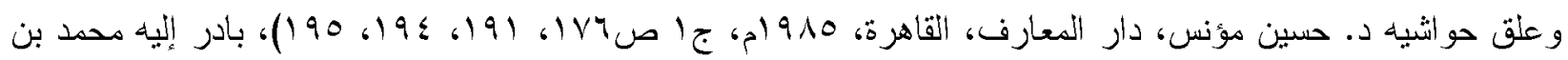
عمر المروذي ودخل في دعوته ولزمه، فولاه قضداء إفريقية، وكانت أيامه صعبة جدًا على أهل السنة المعارضين للدولة الفاطية؛ غير أنه أقى مصبرًا تعستًا عندما سعى به بعض العلماء القيروانيين عند الخليفة عبيد الله المهدي بالمهدية، واتههوه بالإزتثاء واقتناء الأمو ال و أكثروا من ذلك، فقبل المهدي أفو الهم فيه، وعزله، وعذبه، ومكنهم من تتله سنة (الخشني،

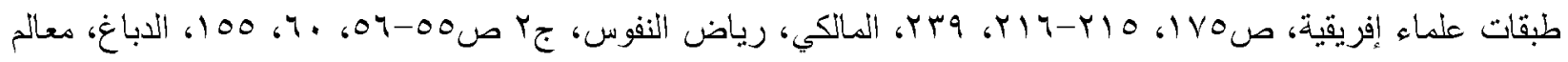

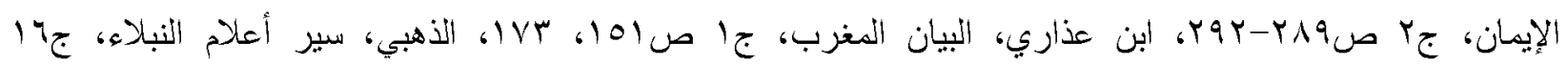
صبr؟، سعد زغلول عبد الحميد، ناريخ المغرب العربي (الفاطميون وبنو زيرب إلى قيام المر ابطين)، منشأة المعارف،

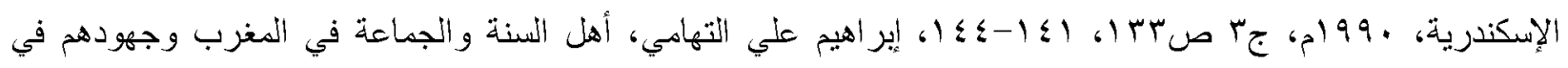
مقاومة الإنحر افات العقدية، جr صبه؛، خالد حسين محمود، ظاهرة العنف في سياسة الفاطميين تجاه رعاياهم خلا

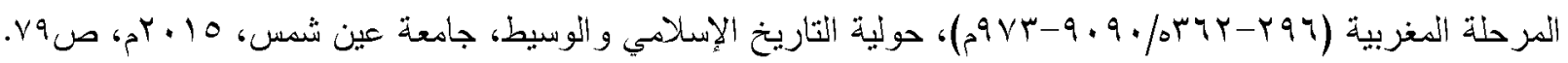

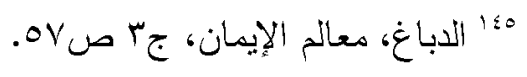

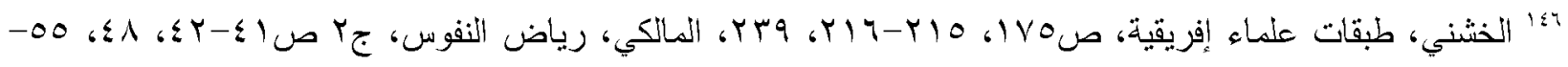

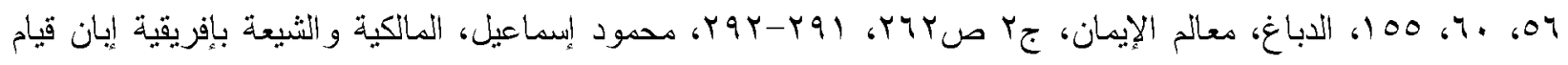

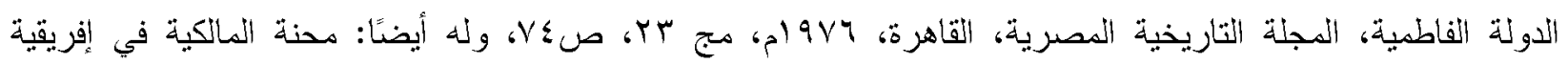

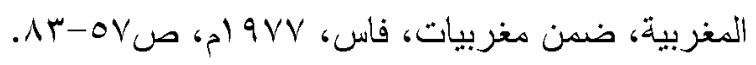

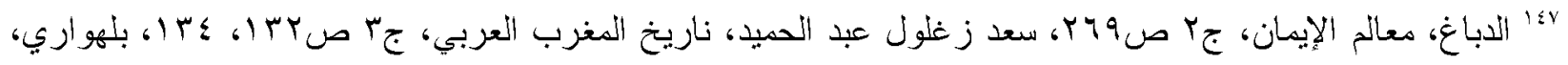

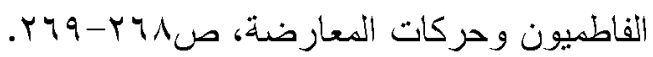

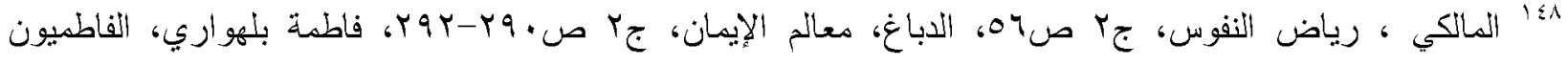

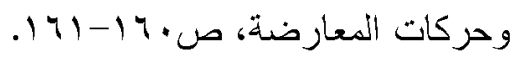


وقد استمر ابن الحَجَّمِ على موقفه السلبي من الفاطمبين الثبعة، فظل مقاطعًا لهم، وتتشدد في التتقيص لرجال دولتهم والتفير عنه، ولم بعبأ بما يتعرض له من نكبتهر؛ وقد أمدنا القاضي عياض برواية فريدة عن مظهر آخر من مظاهز مقاومة ابن الحَجَّام للمد الثبعي وتعرضده للأذبي بسبب ذلك، ولكنه نسب تلاك النكبة إلى القاضي أبي حنيفة النعمان بن محمد بن منصور بن أحد التميمي القيرواني المعروف بابن حيون قاضي قضاة الفاطميين

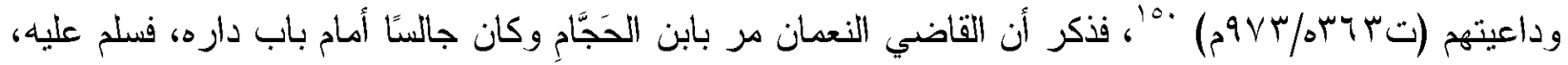
فدعى عليه ابن الحَجَّامِ وعلى الثنبعة، فقال: " حسبنا الله ونعم الوكيل "، فلما كرر القاضي السلام عليه، فرد بمثل رده الأول، فلما انصرف القاضي النعمان، أوغر رجاله صدره ضد ابن الحَجَّام، ور أوا في تصرفه إهانة للقاضي و إذلال له وللثنيعة، فرجع القاضي إلى ابن الحَجَّامِ ينوقد غضبًا، فلما رآه ابن الحَجَّامِ قام وجعل يده على أذنه، وسب القاضي، وقال له: " جعلت أذنك قمعًا لمن يقرب إلى النار لحمك ودمك "، فانصرف عنه، وقد عقد العزم

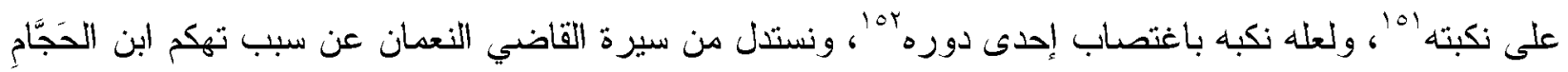

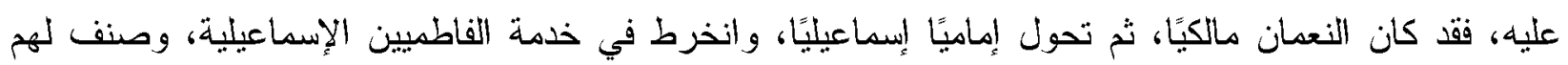

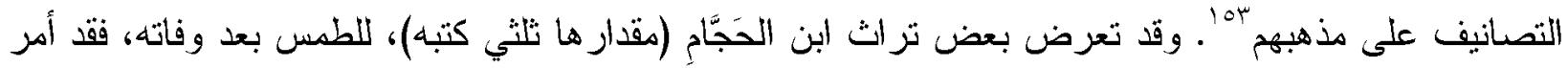

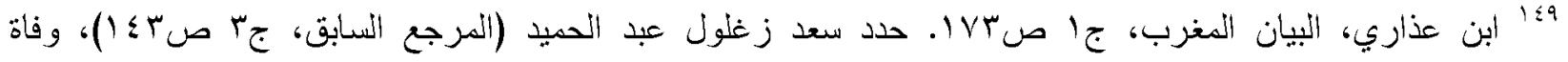

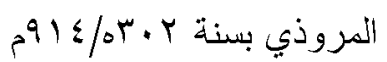
•أحد الأئمة الفضلاء، وكان من أهل العلم والفقه و الدين. وقد تخصص في أصول الفقه الثثبعي وفروعد، والتأريخ النياسي والايني للاولة الفاطمية، وسير أثتهم. وقد وصلت إلينا بعض مؤلفاته، منها: دعائم الإنسلام، وافتتاح الدعوة،

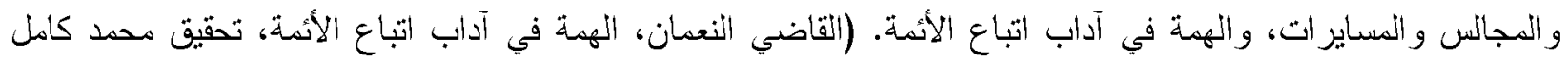

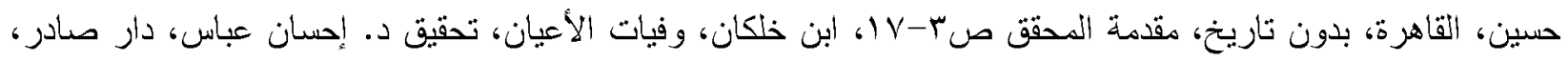

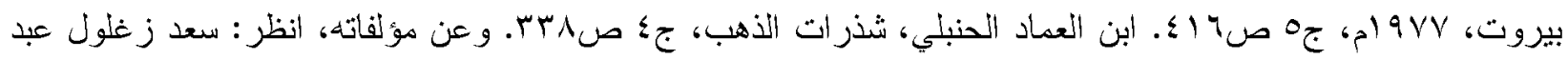

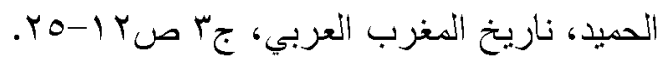

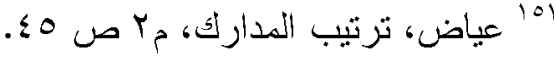

$$
\begin{aligned}
& \text { ror }
\end{aligned}
$$

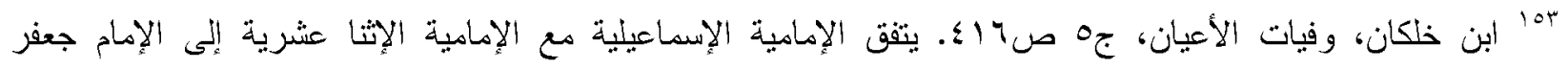

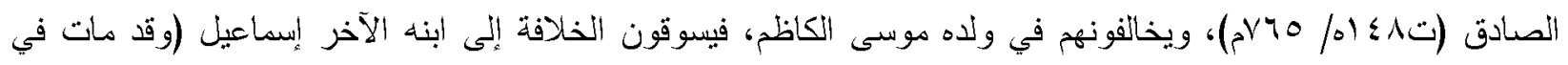

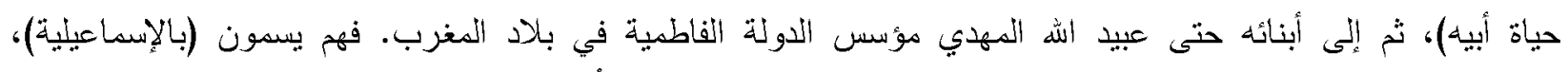

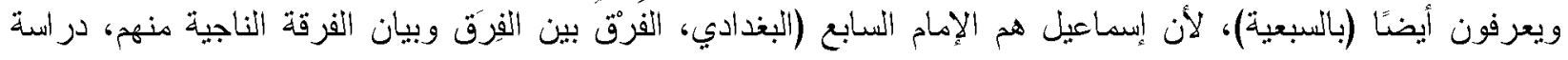

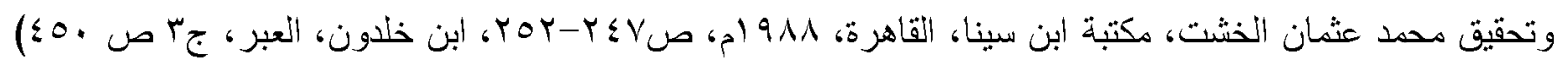




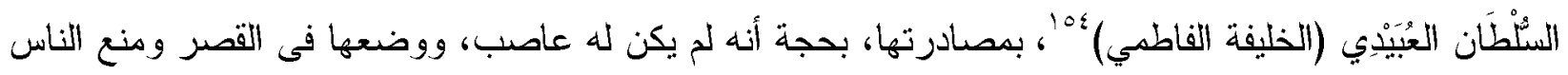

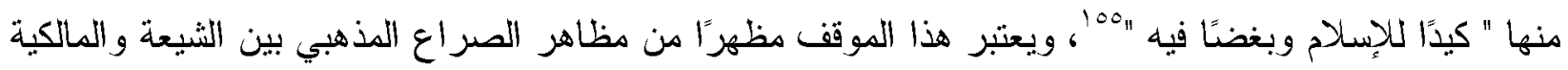
والمالكية في إفريقية؛ فقد كرس الفاطميون جهودهم لإماتة السنة بمختلف الوسائل، فكان مصادرة كتب علماء

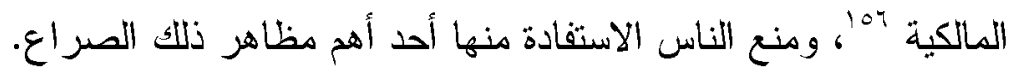
وقد تأثر تلاميذ ابن الحَجَّامِ القيروانيين فيما يبدو بموقفه تجاه المد الثيعي بإفريقية؛ فناصبوا الدولة الفاطمية

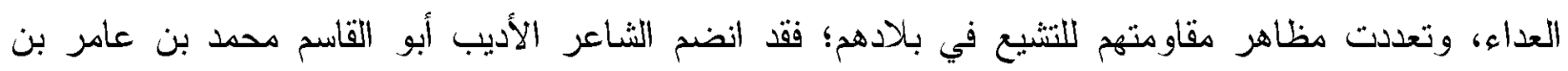

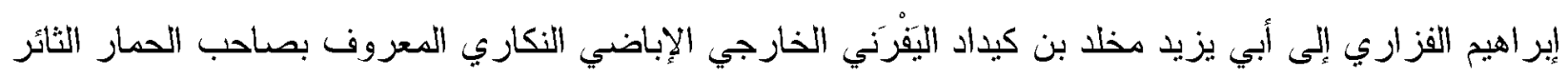

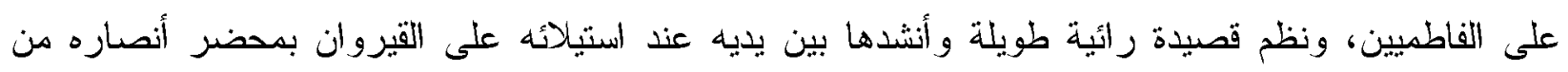

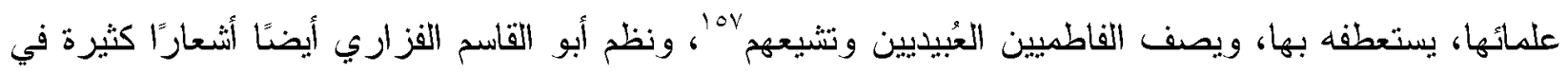

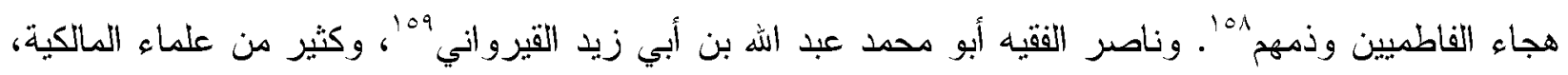

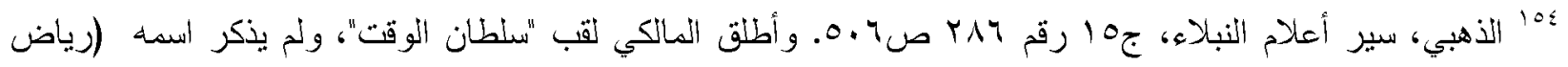

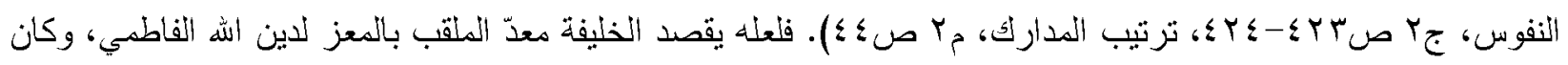

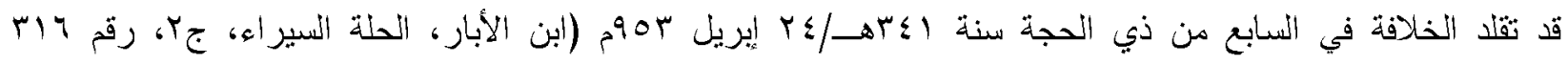

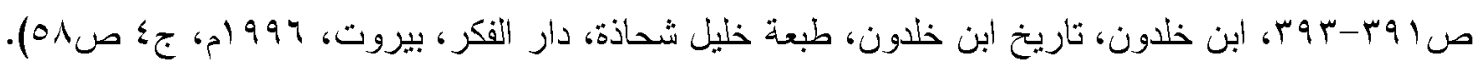

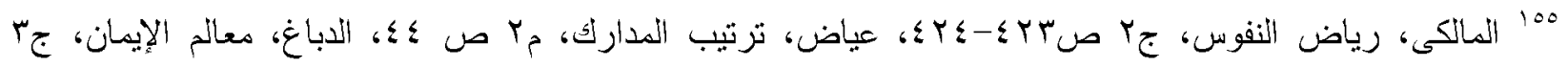

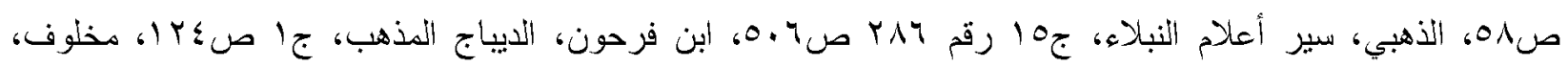

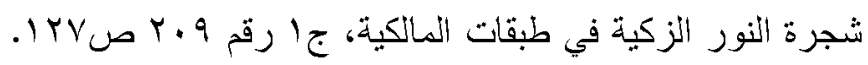
كأذكر المالكي أن رجال الخليفة المهدي صادروا كتب الققيه سعدون بن أحمد الخولاني الزاهد المتعبد بالمنستير

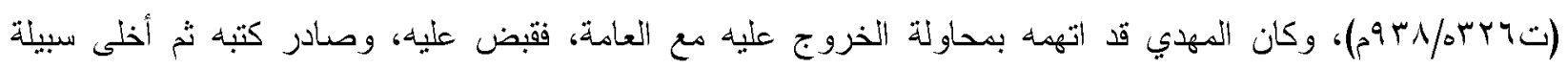

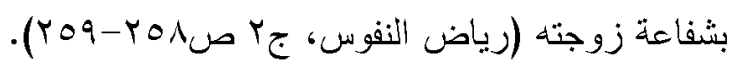

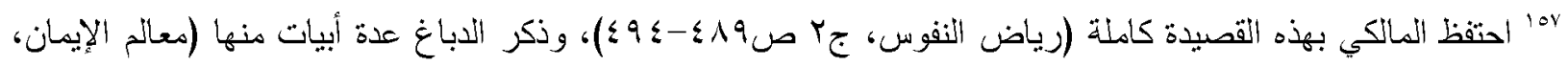

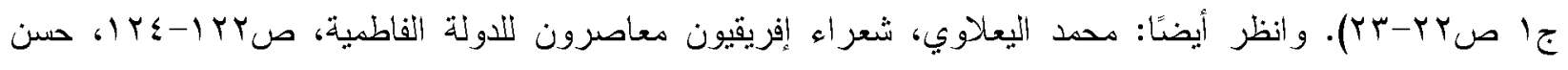
حني عبد الو هاب، مجمل تاريخ الأدب التونسي من فجر الفتح العربي لإفريقية إلى العصر الحاضر ، الطبعة الأولى، مكتبة

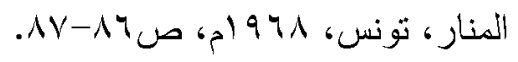

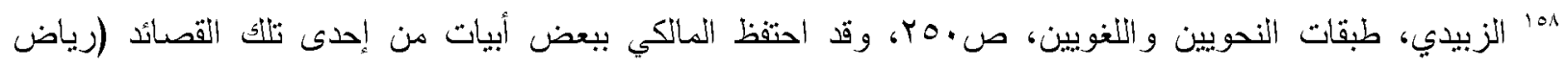

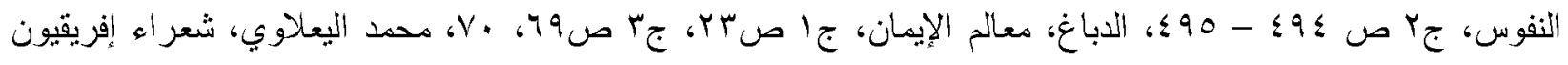

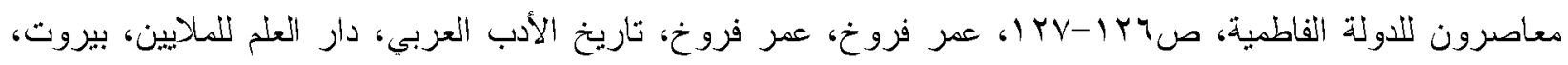


أبا يزيد مخلد بن كيداد في ثورته، فلما فثلت الثورة وهزم الثائر في موقعة تعرف بيوم الجمعة في السابع من

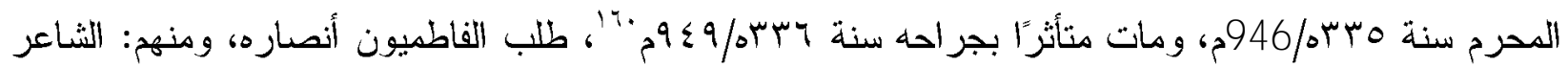

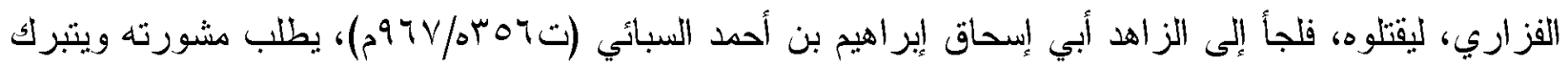
بدعائه، وكان أهل القيروان ينظرون إليه، إذا نزلت الحوادث و المعضلات " لمكانه من العقل والعلم، والمعرفة بصحة الوقت، وكيف تلقى الحوادث " "آ'، فنصحه بتسليم نفسه، فلما حضر بين بدي الخليفة إسماعيل المنصور

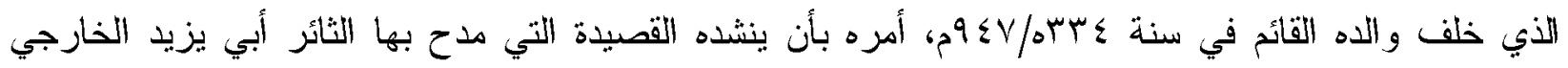
و هجا فيها الفاطميين، فالتمس الفزاري الأمان لكي ينثدها، فأعطاه الخليفة الأمان، فأنثده القصيدة كلها، فلما فرغ غاء

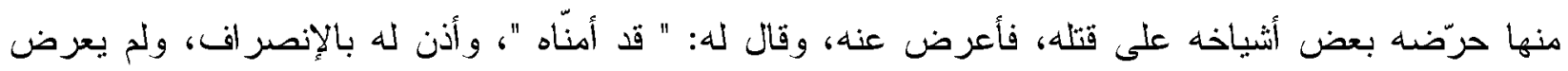

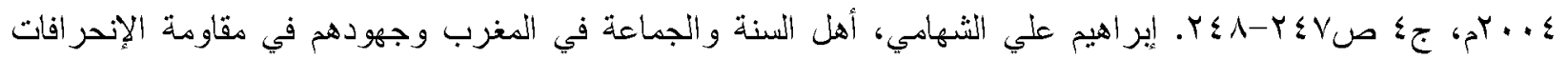

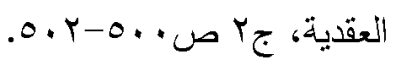

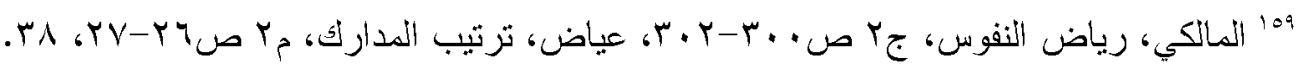

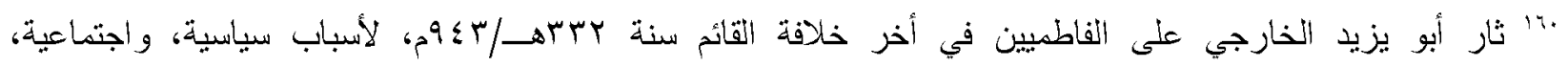

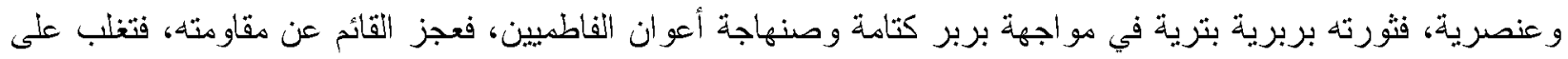

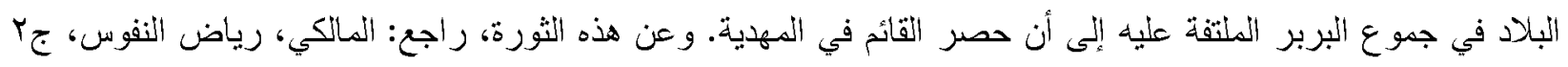

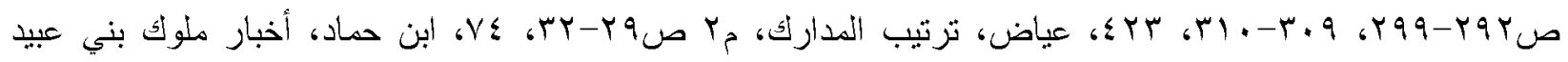

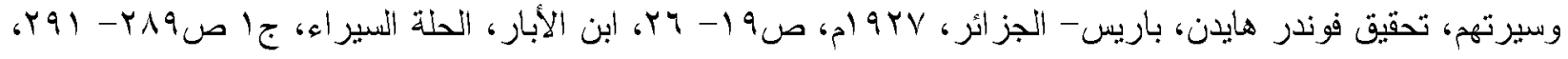
جr صVA

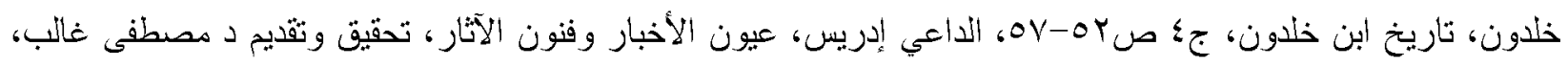

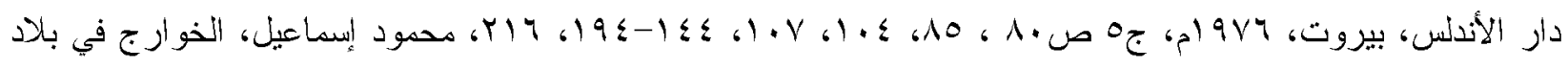

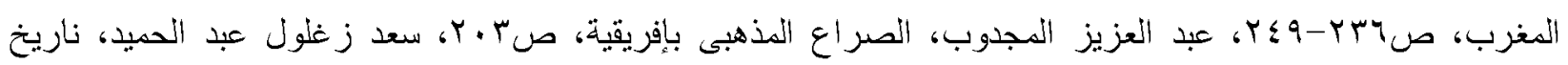

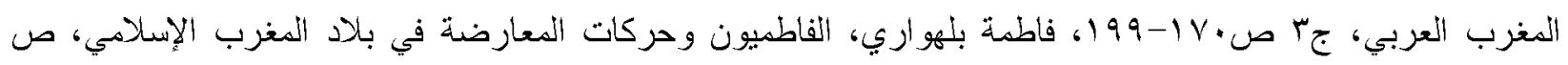

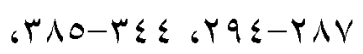

Letourneau (R.), La Revolte d, Abou Yazid au Xme siècle, Les Cahiers de Tunisie, V.1, 1953. آ" كان من أولياء الله الصالحين، وكان الناس ينتفعون بدعائه. صحب أحمد بن نصر، وجلة من أهل العلم، وأخذ عنهم

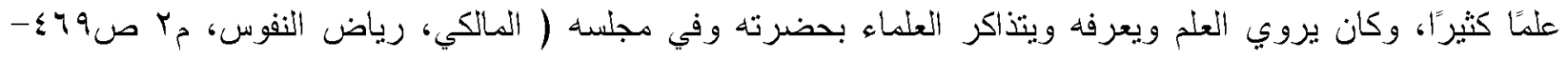

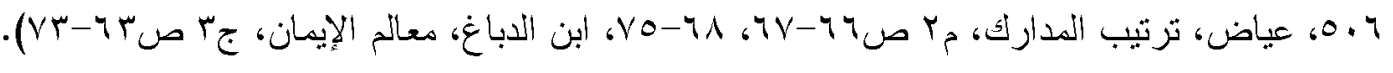


بمكروه، فعافاه اله من شره كما ذكر المالكي بدعاء الشيخ السبائي بَ". وذكر المالكي أن الخليفة إسماعيل المنصور وصل أبا القاسم الفزاري وأكرمه بعد العفو عنه بّا'. ونستدل من الروايات عن سبب صلة الخليفة المنصور للثاعز الفزاري و إكر امه له؛ فقد مدح الفاطميين بقصيدة عصماء رفع من شأنه وجعله فوق جميع المشاهير من

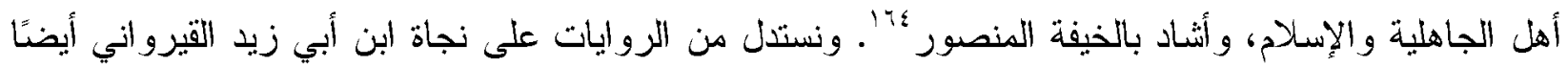
من عقاب الفاطميين، لمساندته الثائر أبي يزيد الخارجي، و اثتز اكه معه في حربهج؛ فقد ظل على قيد الحياة حتى

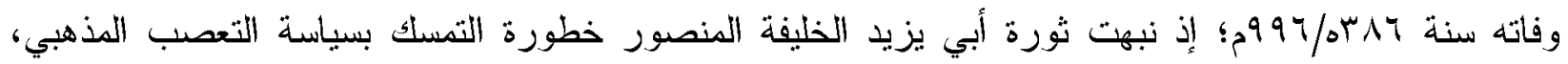
فسلك سياسة التودد و التقرب لأهل السنة عامة، والمالكية خاصة، خوفًا من تجدد ثورتهم ضده با، فكتب إلى أهل

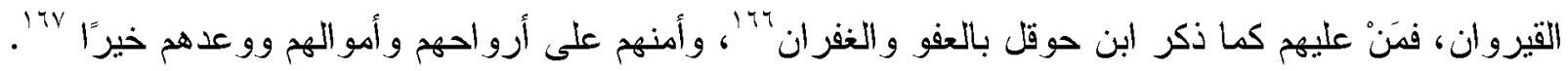

\section{(ه) ميل ابن الحَجَّامِ نحو الزهد واقتداء تلاميذه القيروانيين والأندلسيين به}

نستدل من الإشارات المصدرية على ميل ابن الحَجَّام نحو الزهد، فقد كان صالحًا فاضلًا، ورعًا مسمتًا خانشعًا،

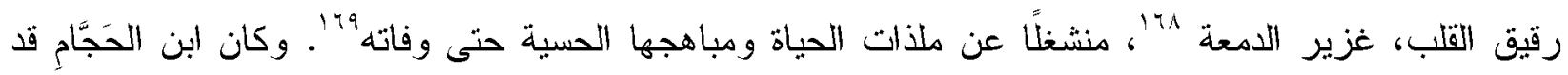
لزم كثير من زهاد عصره بإفريقية وتتلذ عليهم، فعادت عليه بركته؛ فكان يحيى بن عمر ورعًا، زاهدًا، كثير

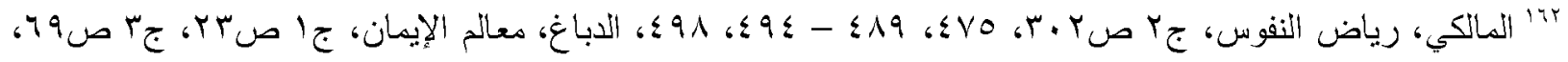

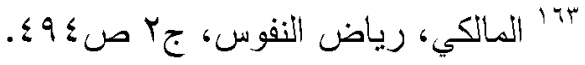

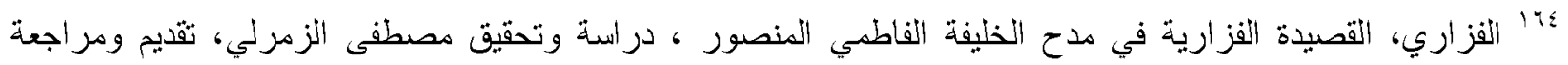

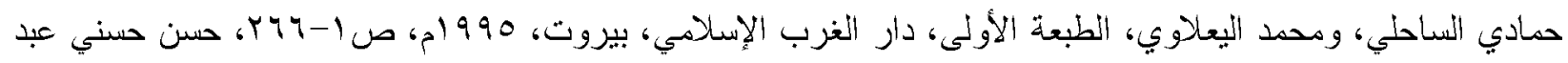

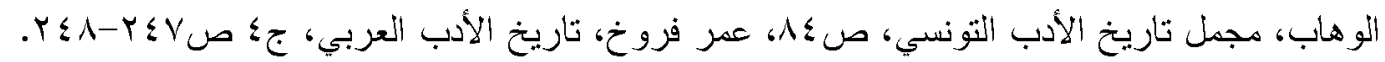

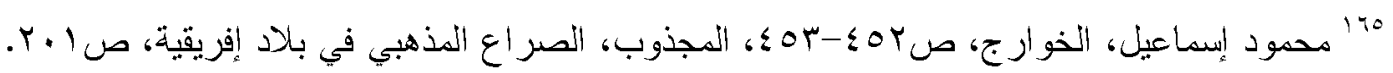

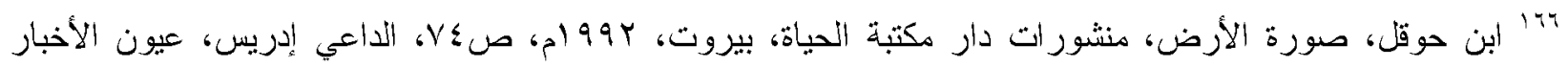

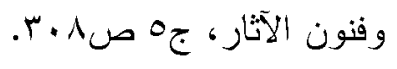

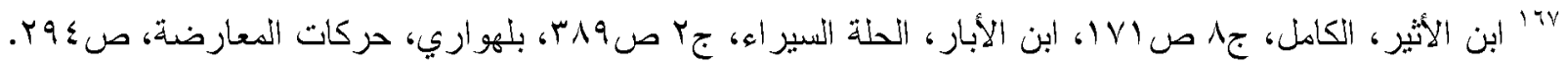

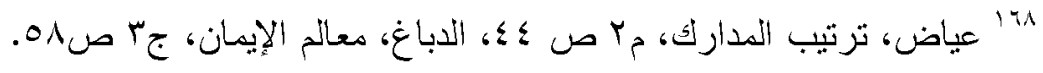

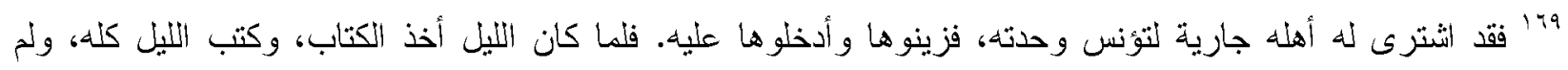

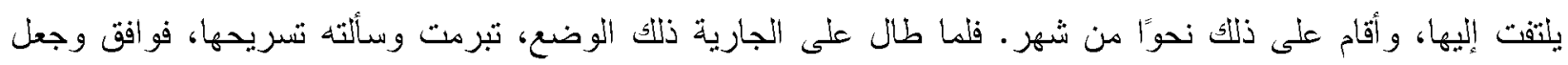

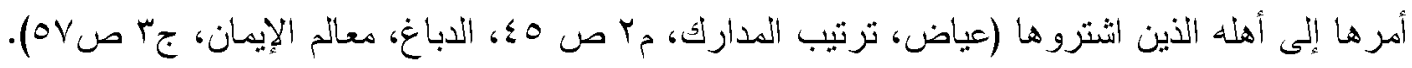


الدعاء و البكاء، ومجاب الدعوة“'، وكان عيسى بن مسكين رجلًا صالحًا مستجاب الدعوة، طويل الصمث، رقيق

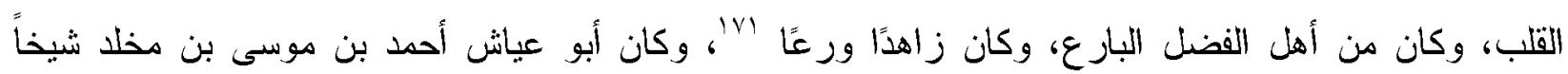
صالحًا، زاهدًا متعبدًا ورعًا سليمان داود الصوافي زاهدًا، وكان غزير الامعة، قرئ عليه كتاب الزهد لسحنون، فما زال يبكي حتى فرغ من

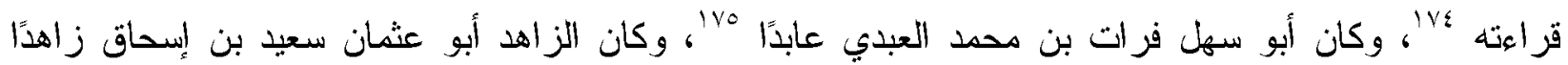

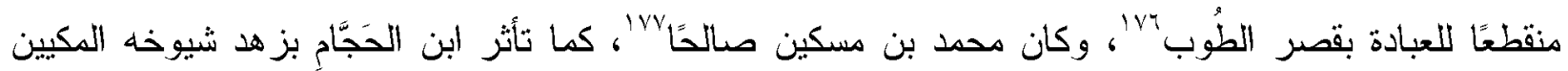

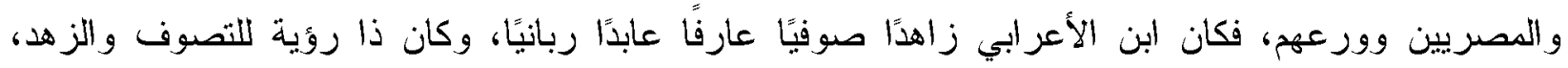

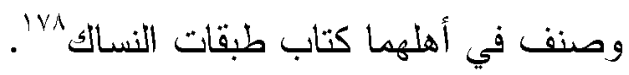

ونستدل من الروايات على أثتر ابن الحَجَّامِ الايجابي في نزوع بعض تلاديذه القيرو انيين و الأندلسيين إلى الزهد

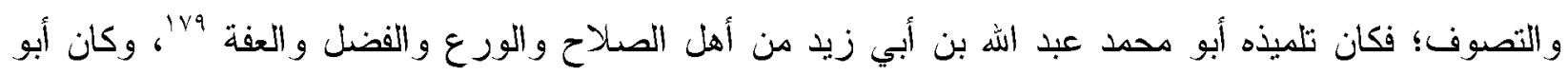

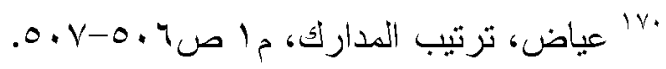

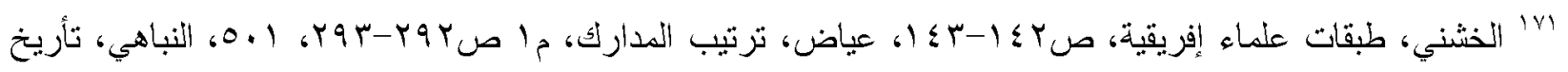

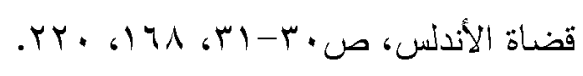

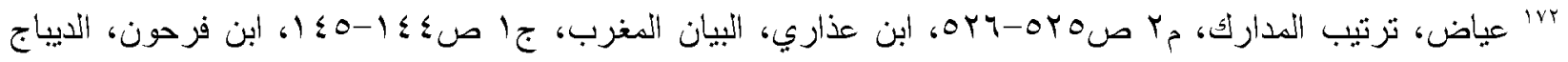

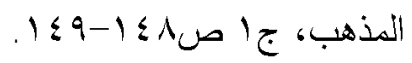

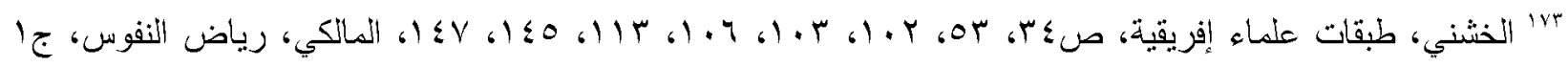

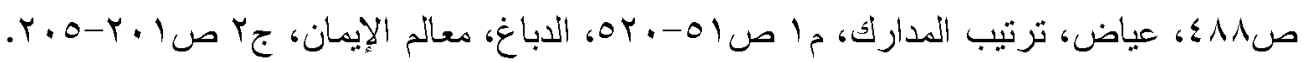

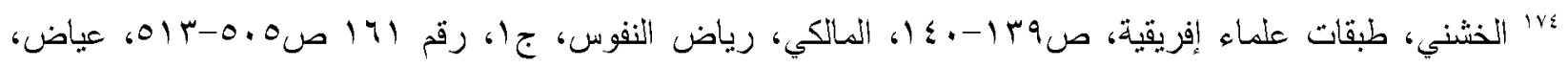

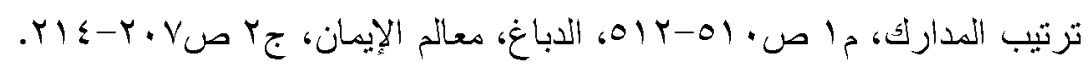

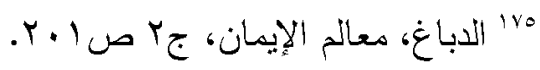

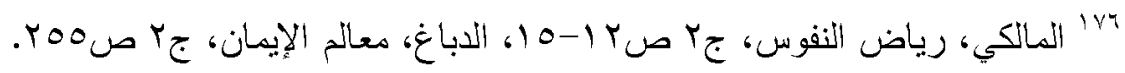

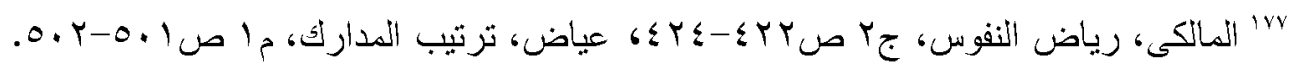

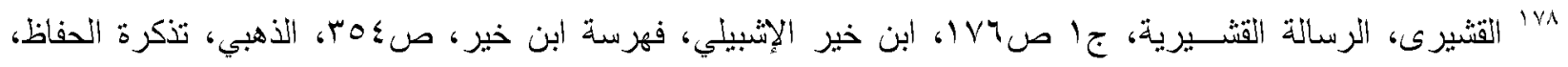

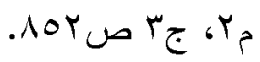

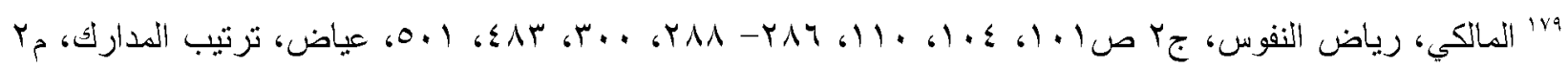

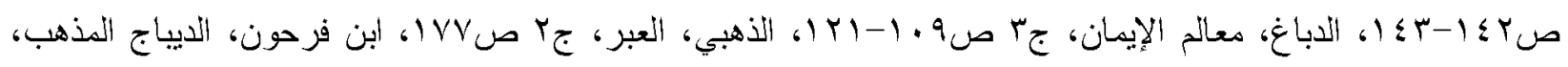


الحسن القابسي من الصالحين الورعين المتقين الزاهدين الخائفين، وصنف كثبًا تدل على ميوله الصوفية، منها: رسالة في الورع، وكتاب حسن الظن بالهة ‘'، وأمدنا القاضي عياض برواية مهمة عن تأثر أبي الحسن القابسي

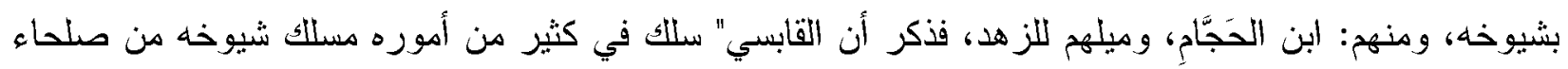

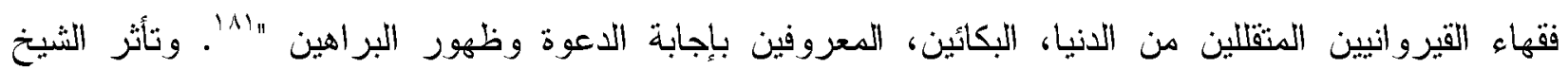

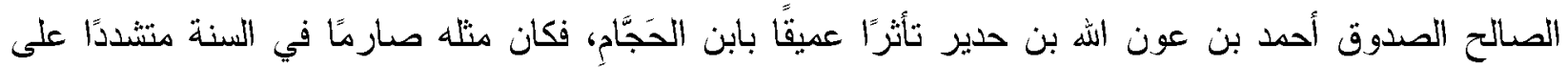

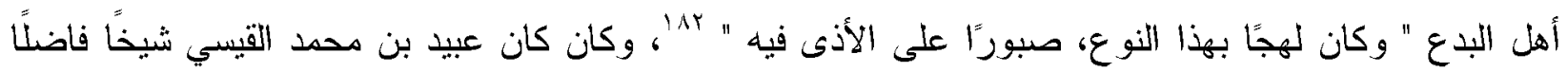

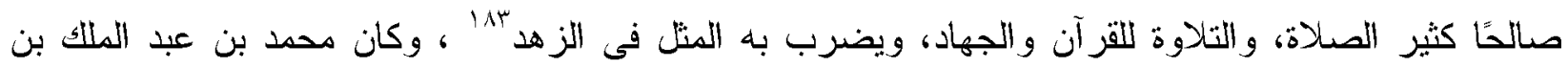

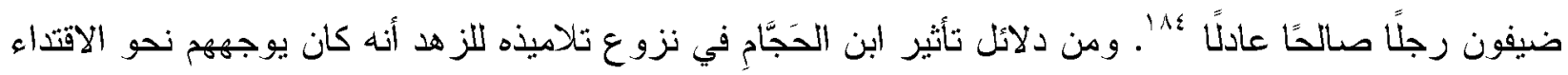
بالزهاد الصالحين المشهود لهم بالصلاح و الطريقة القويمة في الزهد، ودراسة كتبهم في الزهد، وكان ينصحهم بتجاوز سيرة بعض الزهاد ومصنفاتهم في الزهد، فقد أوصى تلميذه الزاهد محمد بن عبد الملك بن ضيَفْون

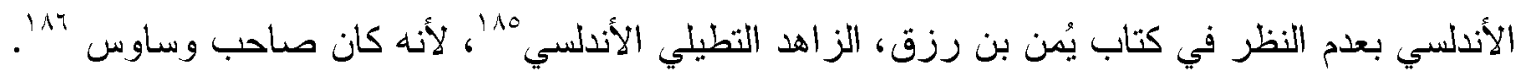

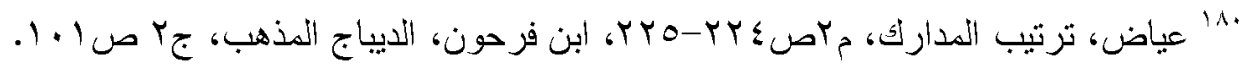

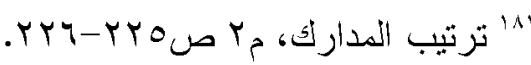

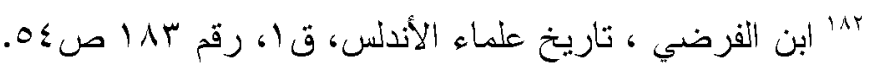

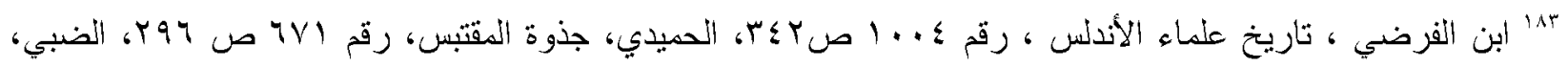

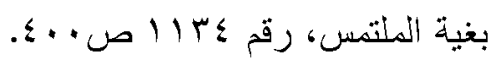

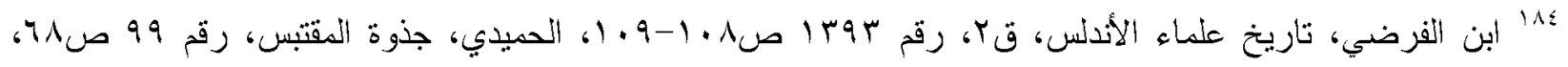

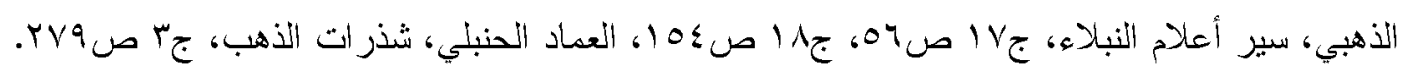

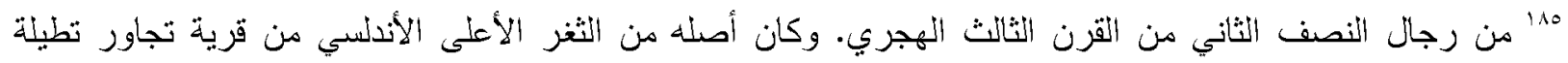
Tudela

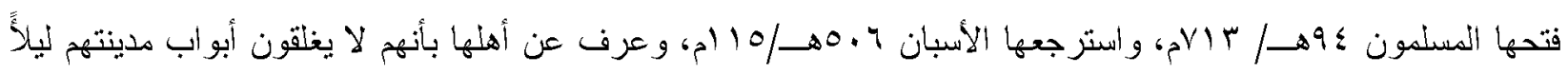

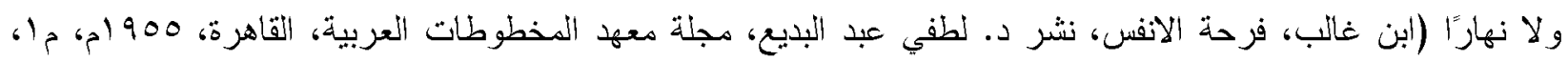

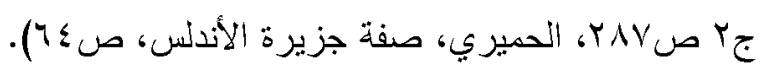
Levi- provencal: La description de L, Espagne de Ahmed al- Razi, Revista al - Andalus, Vol. XV11, Madrid, 1953, pp.76- 78.

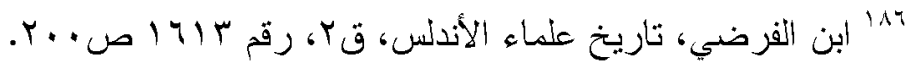


ومن المرجح أن بعض طلاب العلم القيروانيين والأندلسيين تأثروا بشيخهم ابن الحَبَّامِ في موقفه من أهل

البدع؛ نتشددوا معهم في إفريقية والأندلس؛ فقد صنف أبو القاسم مسلمة بن القاسم القرطبي كتابًا في الرد أهل

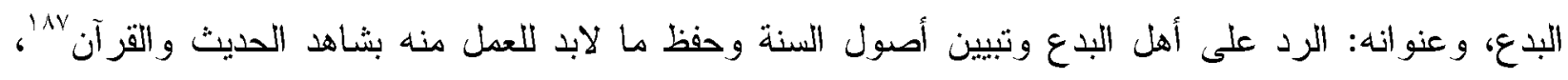
وكان أبو محد عبد الله بن أبي زيد القبزواني بصبرًا بالرد على أهل الأهواء، وصنف في ذلك مصنفات مفيدة،

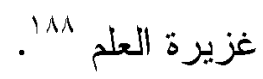

\section{(7) مرويات ابن الحَجَّامِ التي نقلها عنه طلاب العلم الأدلالسيين إلى بلادهم}

أدرك ابن الحَجَّامِ أهمية العلم، بالتأليف فيه وتقيبد المرويات التي سمعها عن شيوخه، وكان شيخه عيسى بن مسكين قد روى لتلاميذه، عن شيوخه، أن الصحابي الجليل عبد الله بن عباس (تش؟هـ/

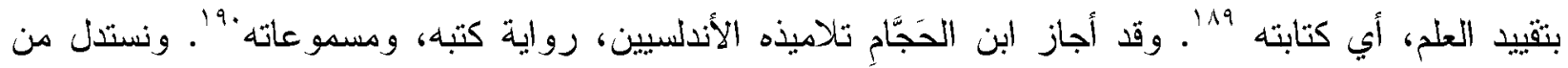
الروايات أن معظم المرويات التي نقلها هؤلاء الطلاب عن شيخهم ابن الحَجَّامِ كانت من مسموعاته التي سمعها عن شيخيه عيسى بن مسكين، وأخيه محمد بن مسكين، عن شيخها الإمام المُحدّث المُصنَف محمد بن عبد الله بن

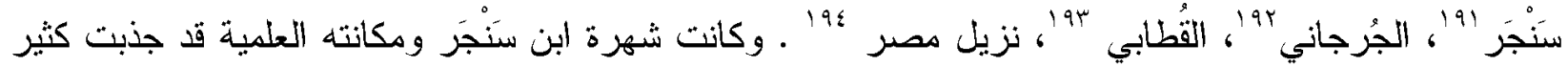

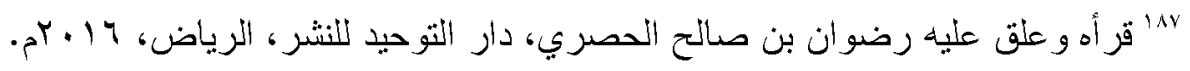

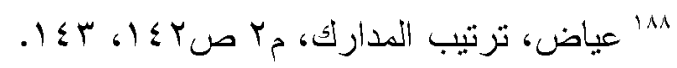

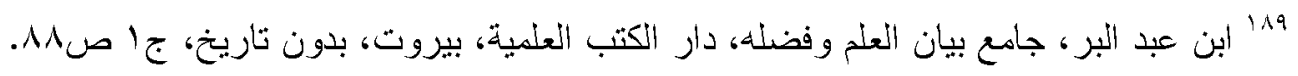

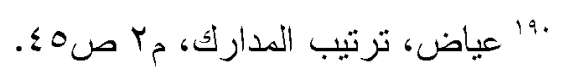
(919 ابن ناصر الأمشقي، توضيح المشتبه في ضبط أسماء الرواة و أنسابهم و أنقابهم وكناهم، تحقيق محمد نعيم العرقسوسي،

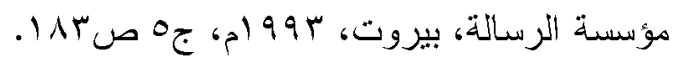

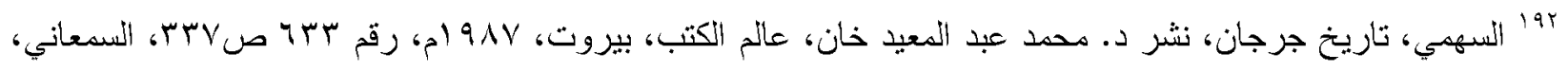

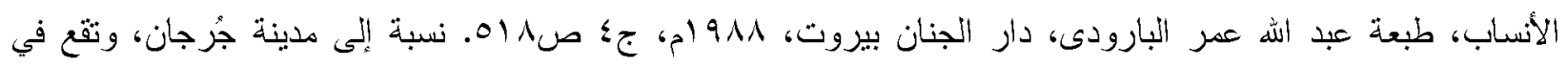
أقصى شمال بلاد فارس جنوبي شرفي بحر قزوين. وقد بدأ الفتح الإنسلامى لها في عهد الظليفة عمر بن الخطاب سنة

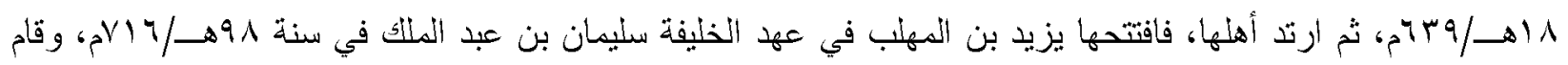

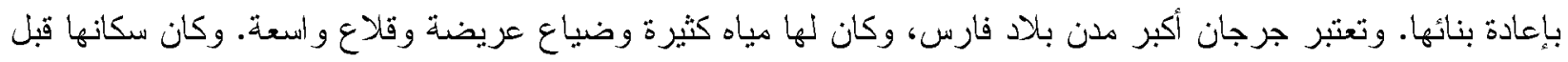

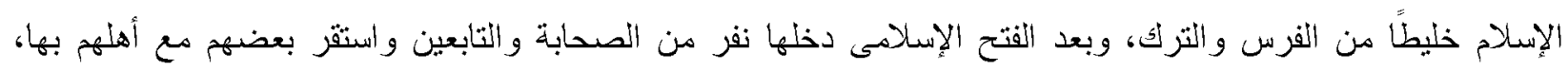
وهاجرت إليها بعض عثائر القبائل العربية واستقرت بها، فامتزج العنصر العربى بالعناصر المحلية وغدت جرجان بلدًا 
من طلاب العلم المغاربة والأندلسيين، فحرصوا على السماع منه أثناء رحلاتهم العلمية إلى مصر ومراكز الثقافة الإسلامية المشرقية، فقد رحل عبسى بن مسكين إلىى المشرق رحلتين، غير أنه لم بسمع من ابن سَنْرَ فى رحلته الأولى قبل سنة . .

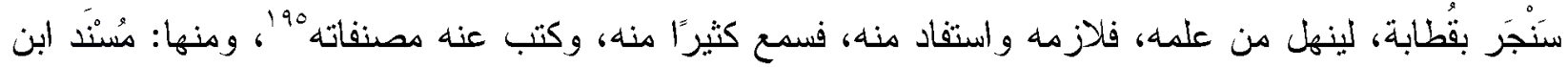

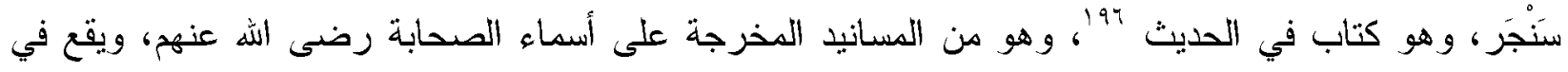

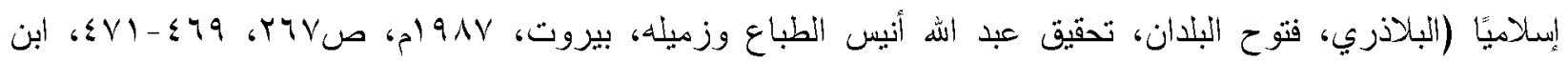

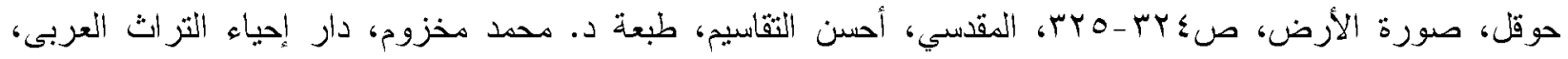

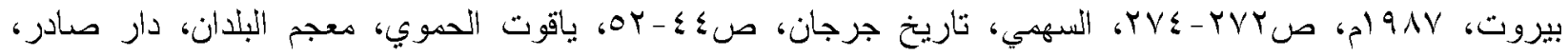

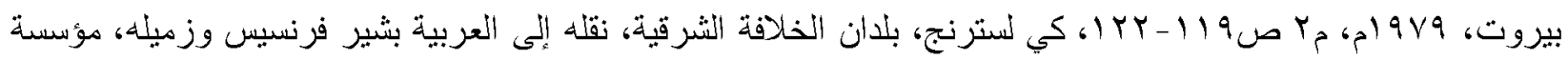

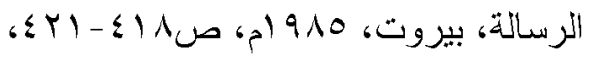

Donner (F.), the Early Islamic Conquests, Princeton University Press, Princeton, New Jersey, 1981, p.438, Hartmann (R.)- Boyle (J.A.), Gurgan, The Encyclopedia of Islam, New Edition, Brill, Leiden, 1983, p.1141).

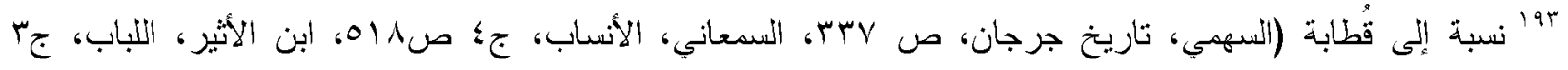

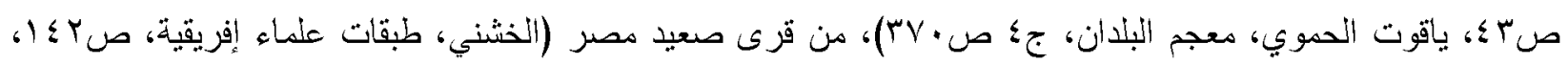
النسيوطي، حُسن الدحاضرة في أخبار مصر والقاهرة، تحقيق الدكتور علي محمد عمر، مكتبة الخانجي، التاهرة،

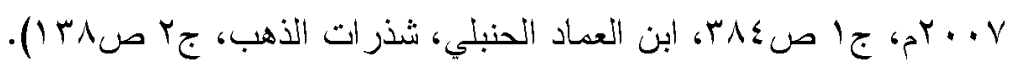

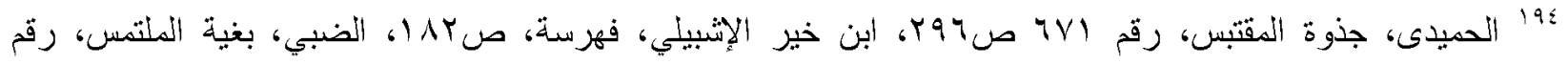

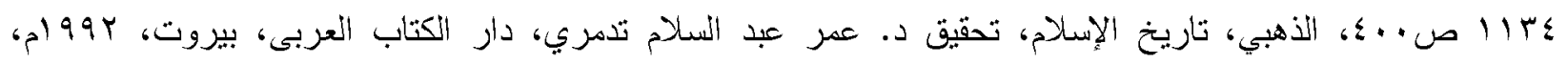

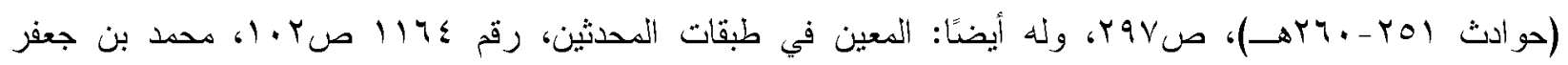

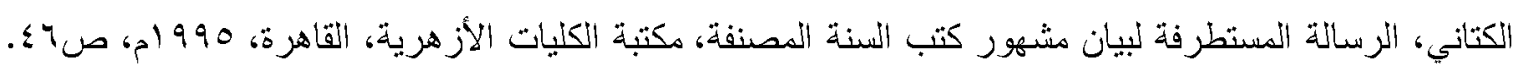

$$
\text { 190 } 190
$$

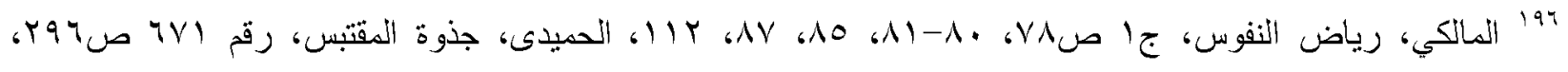

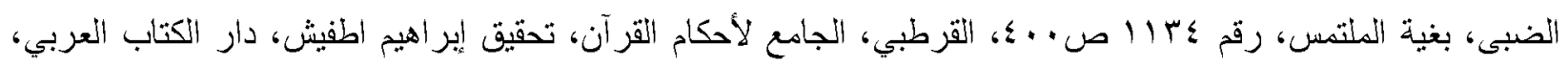

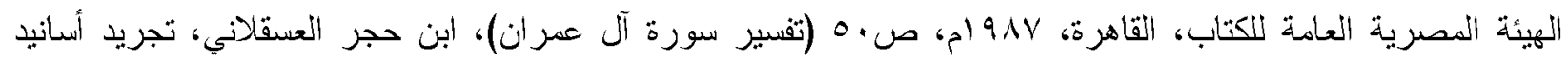

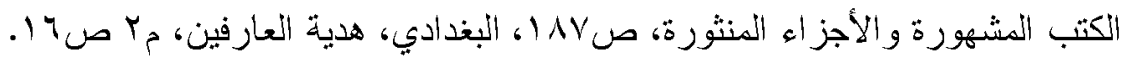




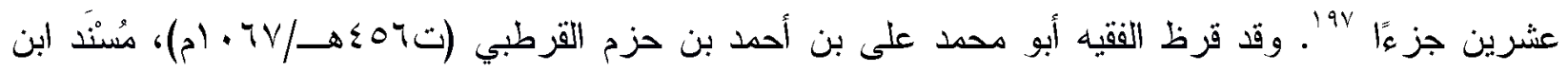

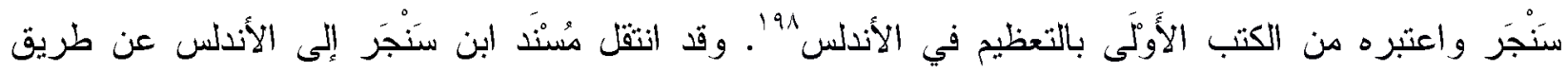
طلاب العلم الأندلسيين الذين سمعوه بإفريقية من عبد الله بن مسرور ابن الحَجَّمِ، عن شيخيه عيسى بن مسكين،

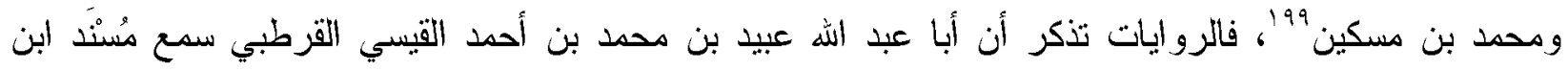

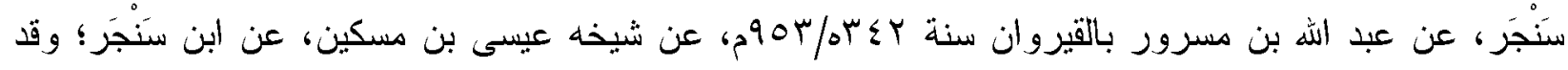
رواه أبو عبد الله عبيد بن محمد القيسي القرطبي لتلاميذه الأندلسيين، فقرأه عليه أبو عمر يوسف بن عبد الله بن

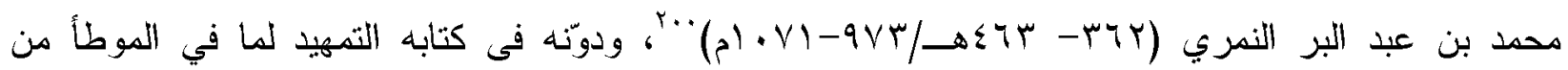

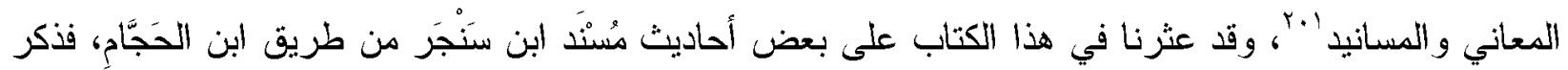
ابن عبد البر: أخبرنا عبيد بن محمد، قال: حدثا عبد الله بن مسرور، قال: حدثنا عيسى بن مسكين، قال: حدثا

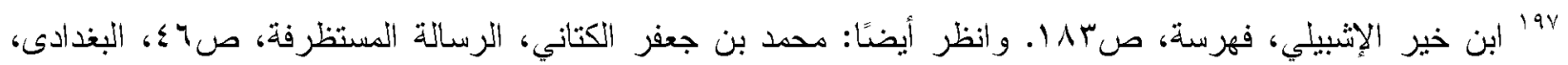

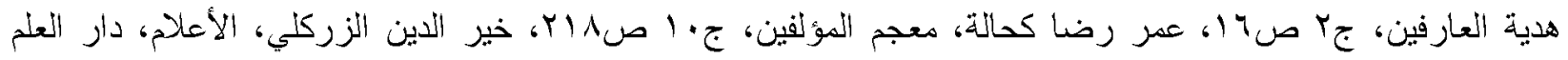

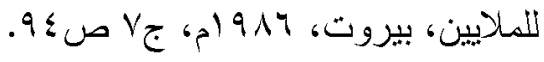

191ا الذهبي، سير أعلام النبلاء، جه| صس •r. وكان ابن حزم قد سمع هذا الكتاب من شيخه عبد الرحمن بن مسلمة الكناني، عن أحمد بن خليل، عن خالد بن سعد، عن أحمد بن عمرو بن منصور الإنبيرب، عن ابن سنْجر بإسناده، وقد حدّث

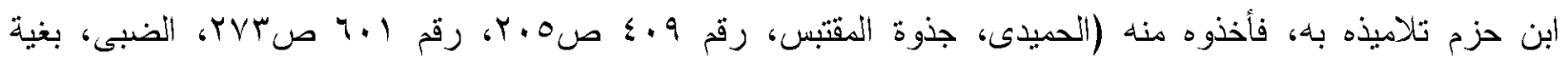

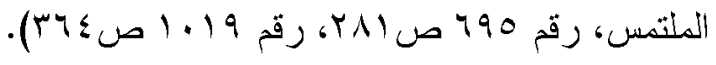

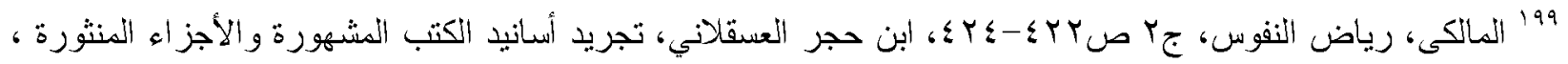

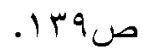

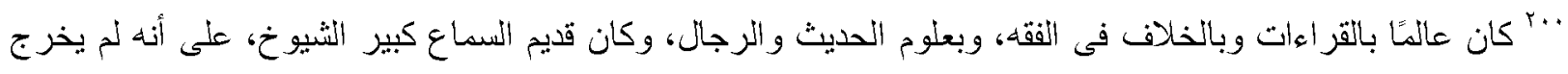
عن الأندلس، فسمع من أكابر أهل الحديث بقرطبة وغيرها، ومن الغرباء القادمين إليها. وألف مما جمع تواليف نافعة

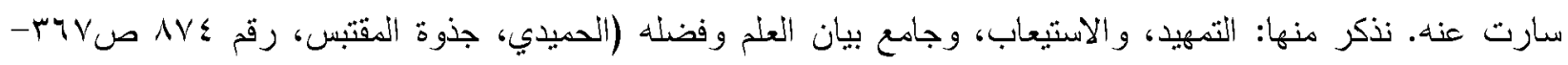

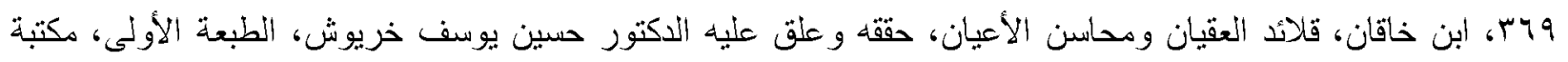

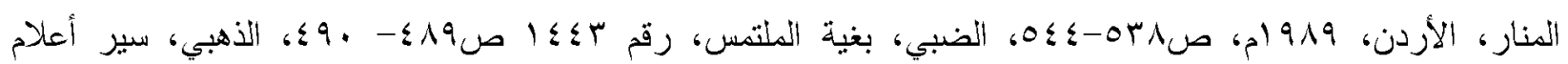

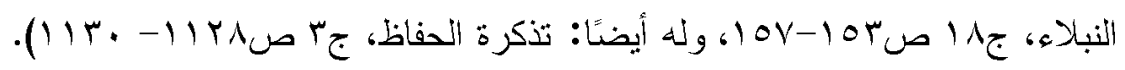

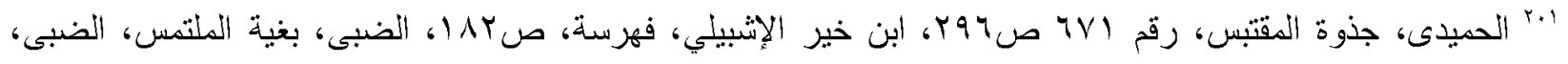

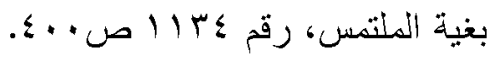


ابن سنجر ، قال: حدثا موسى بن داود، عن أبي الثعثاء، عن ابن عباس، قال: رسول الله صلى اله عليه وسلم : "

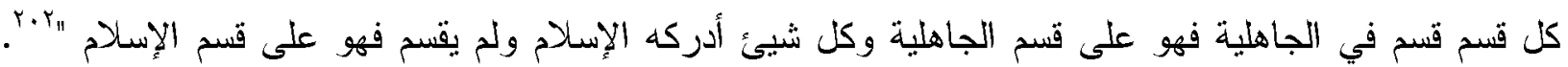

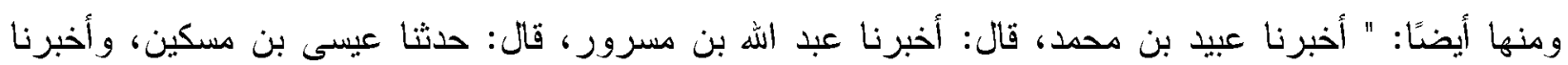
قاسم بن محمد، قال: حدثا خالا بن سعد، قال: حدثا أحمد بن عمرو، قالا جميعا: حدثا محمد بن عبد الله بن سنجر ، قال: حدثا يزيد بن هارون، قال: أخبرنا هشام الاستو ائي، عن بحيى بن أبي كثثر، قال: حدثي عياض أنه

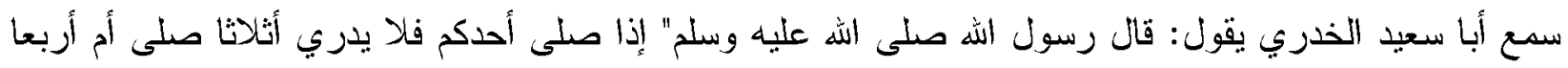
فليتحر الصواب ثم ليسجد سجدتي السهو، وإذا أتى أحدكم الثنطان في صلاته فقال له إنك أحدث،، فلا ينصرف

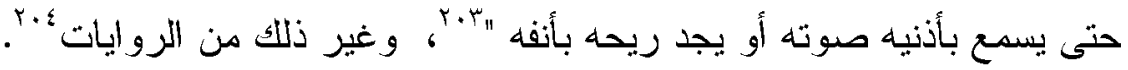

وكان أبو عبد الله عبيد بن محمد القيسي القرطبي قد عاد من رحلته العلية المشرقية الأولى بعد سنة

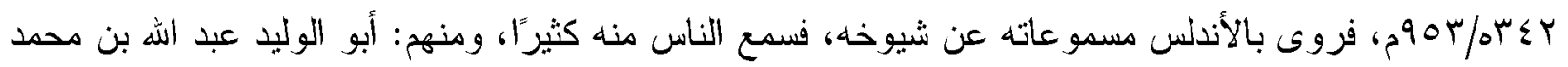

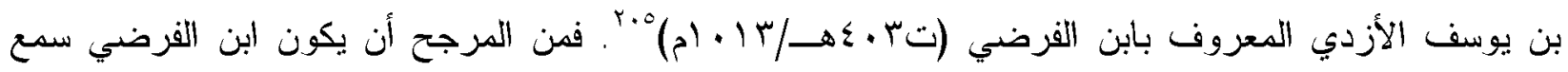
هنه أيضًا مسند ابن سَنْجر من طريق ابن الحَجَّامِ.

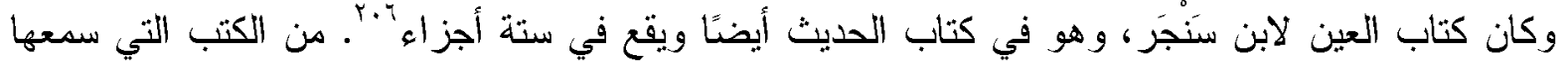
ابن الحَجَّامِ عن شيخه عيسى بن مسكين بإِفريقية، وقد رواه ابن الحَجَّامِ لتتلاميذه المتحلقين حوله بالقيروان، فانتشر هناك، وأخذه عنه تلاميذه الأندلسيون وحتّثو به في حلقاتهم، وقد أدخله تلميذه الفقيه المحدث أبو جعفر أحمد بن

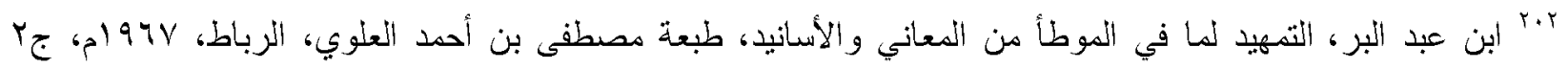
ص صג

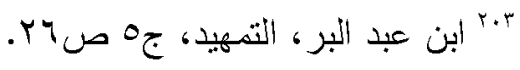

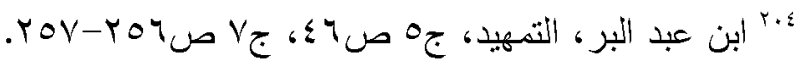

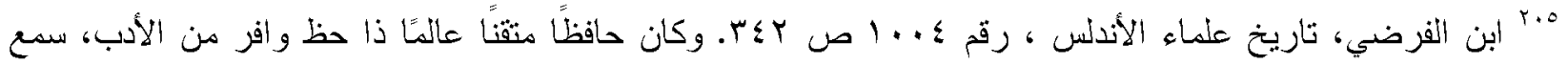

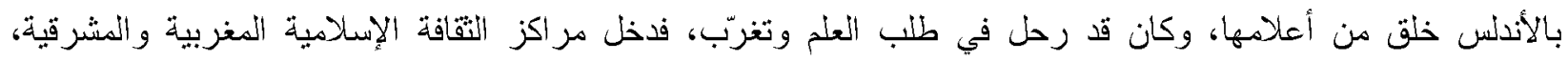

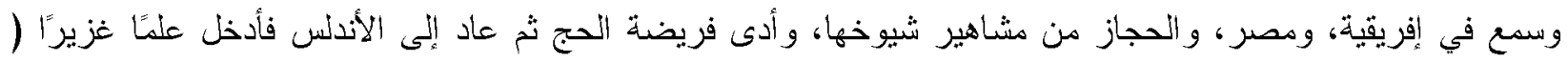

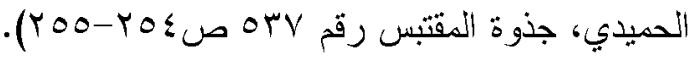

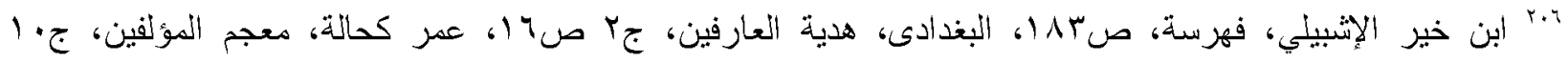

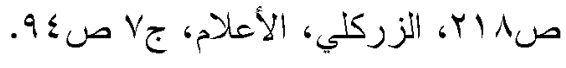




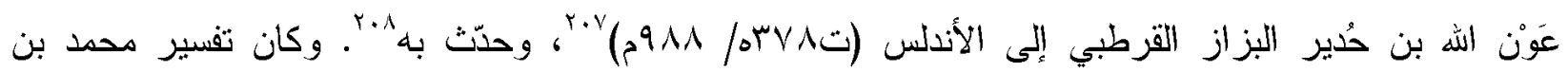

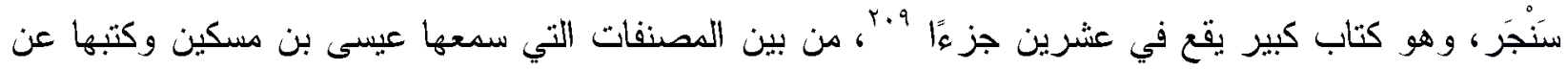
شيخه ابن سَنْجرَ ، وعند عودته إلىى إفريقية قام برو ايته عنه، فسمعه منه خلق من تلاميذه بكورة الساحل، منهم: ابن

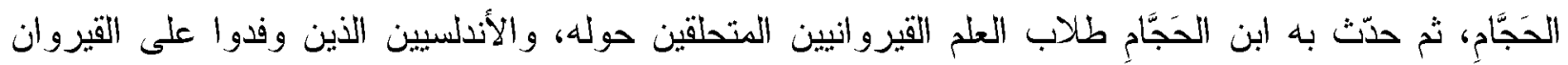
لينهلوا من علم شيوخها، فسمعه منه الحافظ المحدّث محمّّ بن عبد الملك بن ضيَّفون بن مروان اللخمي الرصافي

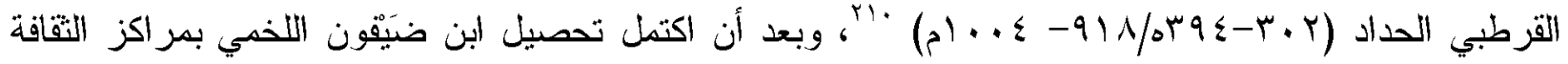
الإسلامية التي رحل إليها سنة ^بr/9 9/9م، عاد إلى الأندلس، وحدّت بما سمعه من شيوخه هناك، فقد كان شيخًا

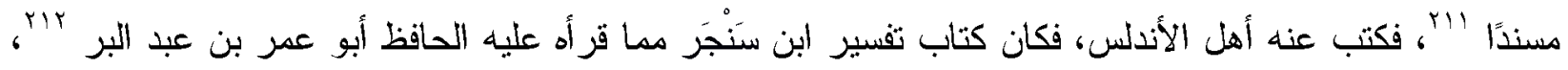

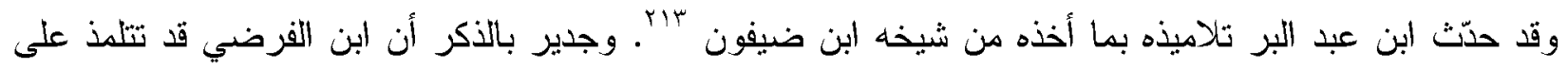

Y.Y. كان يروى عن قاسم بن أصبغ البيانى، وعن أبى سعيد بن الأعر ابى، ورحل فسمع بمكة، وبطر ابلس الثام، ودمشق،

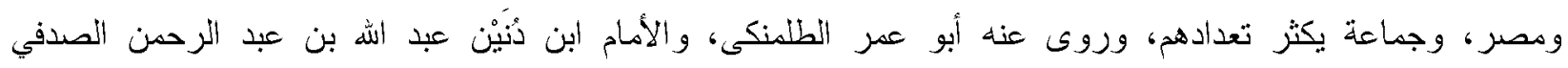

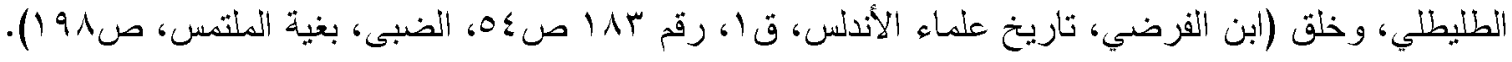

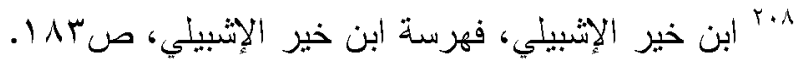

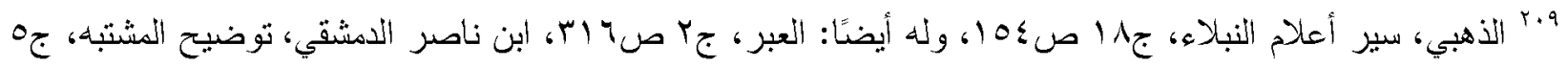

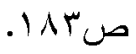

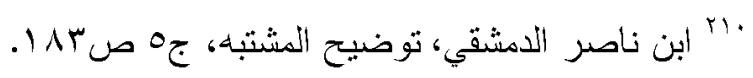

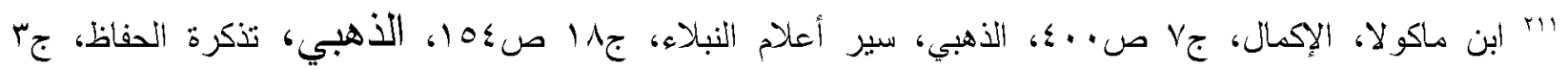

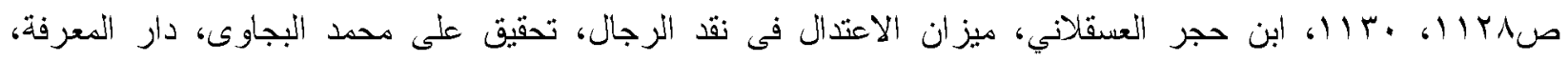

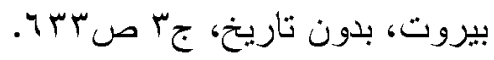

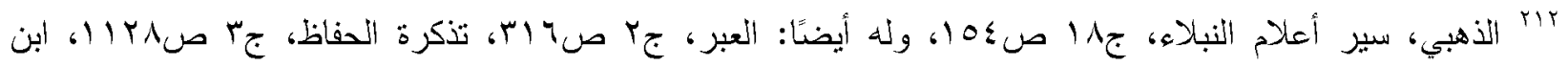

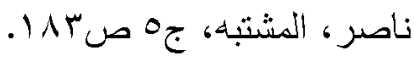

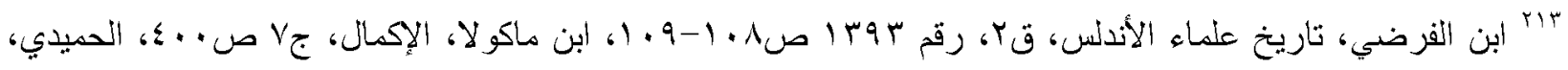

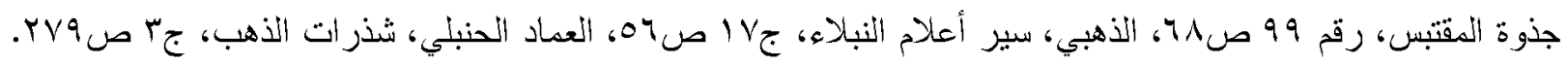




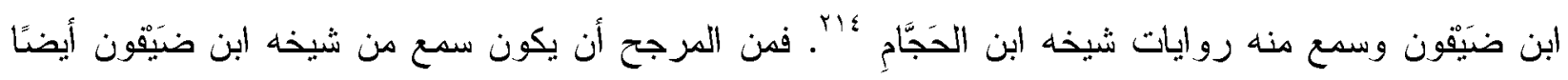
مؤلفات ابن سَنْجر برواية عبد الله بن مسرور.

وقد انصرف أبو القاسم مسلمة بن القاسم بن إبراهيم بن عبد الله بن حاتم القرطبي إلى الأندلس، وقد جمع علمًا

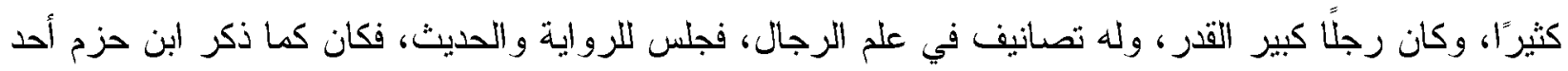

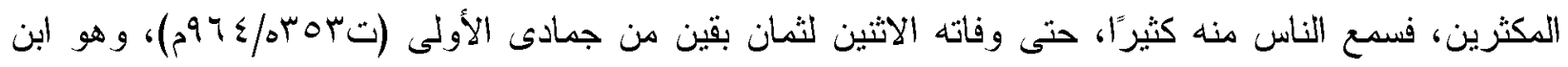
ستين سنة"ro. فمن المرجح أنه حدّث تلاميذه بما سمعه من مرويات شيخه ابن الحَجَّامِ، عن شيوخه، ومنها:

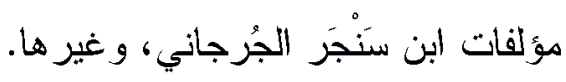

ولم ينقل طلاب العلم الأندلسيين عن شيخهم ابن الحَبَّام مصنفاته ورواياته الحديثية فحسب، إنما نقلوا عنه أيضًا أرائه النقدية في الرجال ومؤلفاتهه، خاصة علماء الأندلس المقيمين في إفريقية، فكان ابن الحَبَّمِ ينهي تلاميذه عن

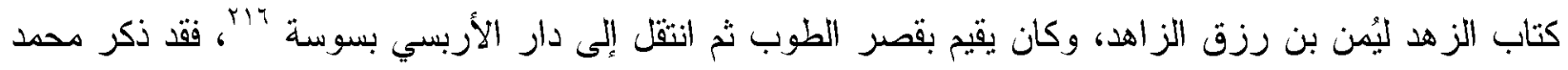

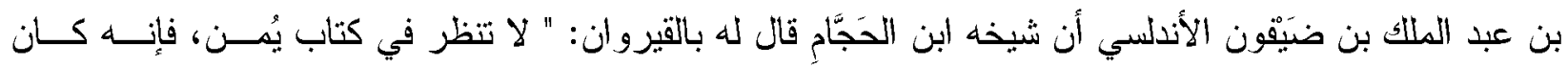
صاحب وساوس " ، وقد روى ابن ضيفون هذه الزواية لتلاميذه، ومنهر: ابن الفرضي، فاحتفظ بها في كتابه تاريخ

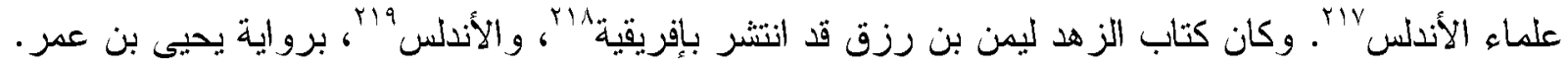
وفاة ابن الحَجَّامِ واستمر ار أثُره العلمي غير المباشر في إفريقية والأندلس (V)

وبعد عمر طويل في طلب العلم ونشره، فاضت روح عبد الله بن مسرور ابن الحَجَّام لتلقى بارئها في ليلة

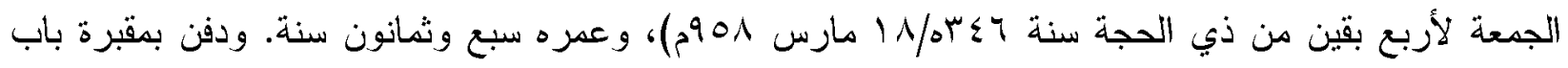

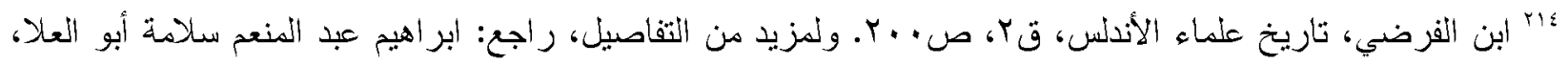

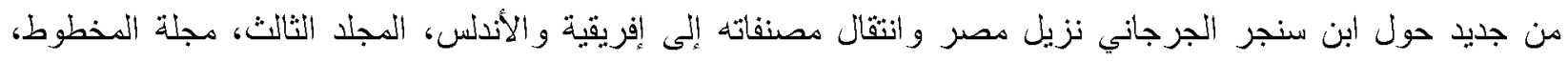

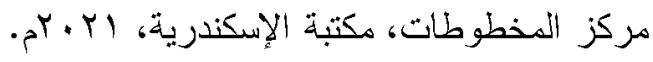

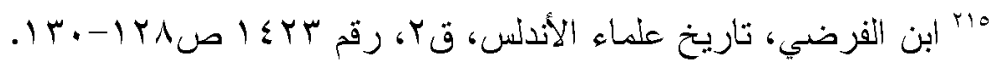

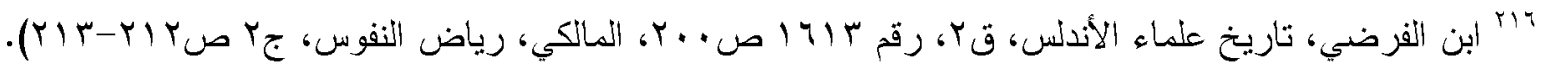

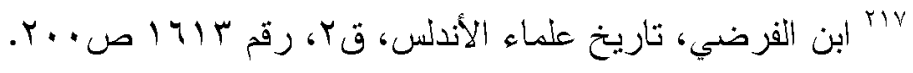

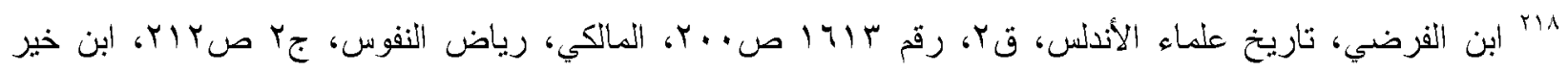

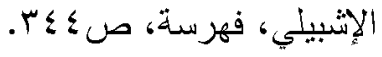

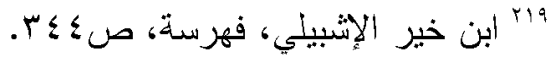


سلم، قرب شقران وأبي ميسرة 'r.r. وكان سبب موته أنه اصطلى ونعس، فالتهمت النار بثيابه، واحترق إلا

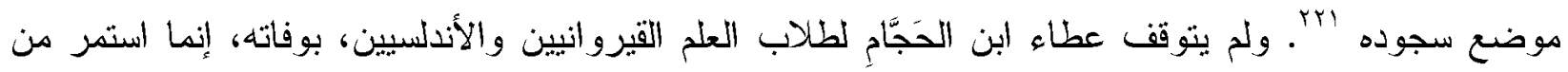

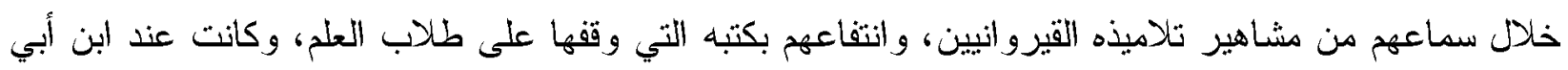

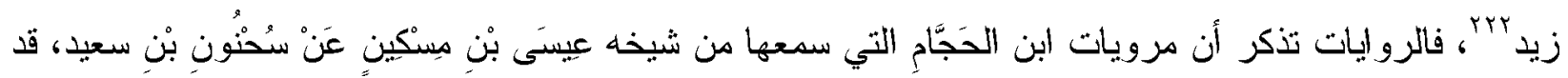

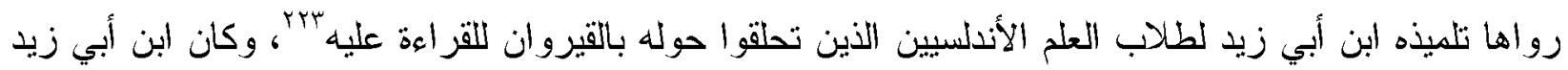

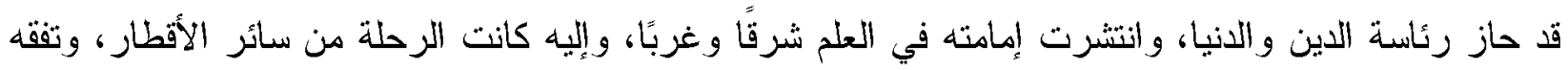

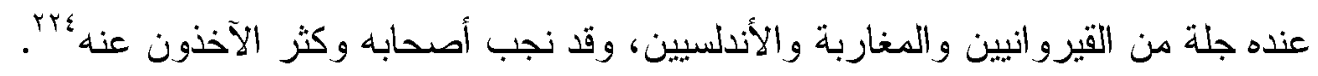

و استمر عطاء ابن الحَجَّمِ لطلاب العلم الأندلسيين أيضًا بعد وفاته بطريق غير مباشر؛ من خلال تتلدذهم

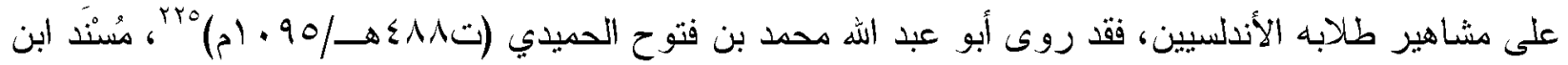
سَنْجر عن شيخه ابن عبد البر من طريق ابن الحَجَّام؛ وكان ابن عبد البر قد أجاز الحميدي رواية كتبه

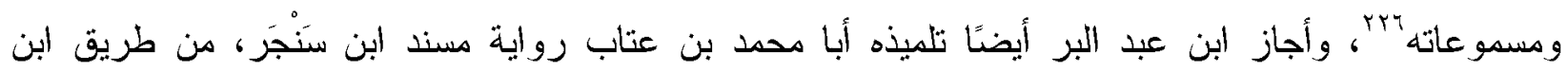

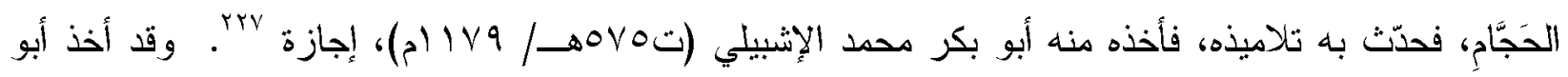

$$
\text { rr. }
$$

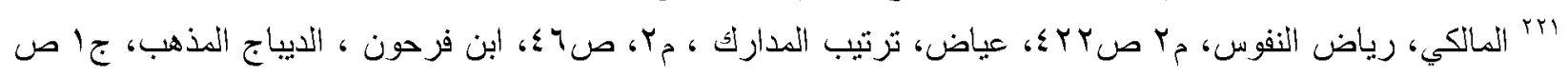

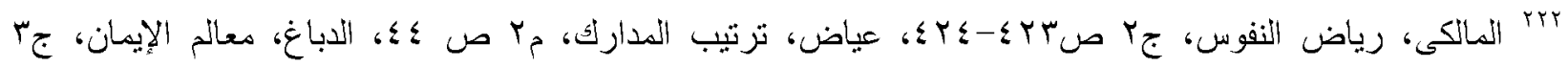
ص ص1.01

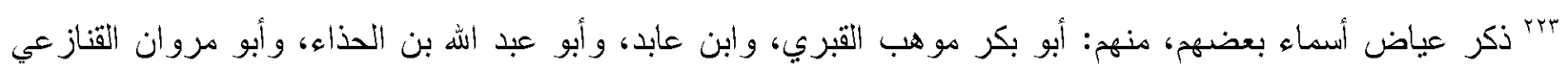

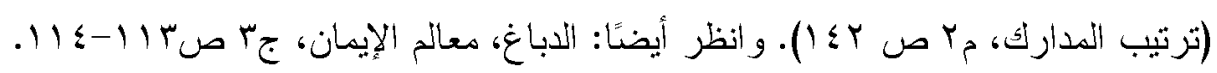

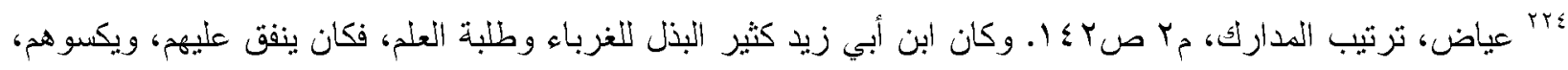

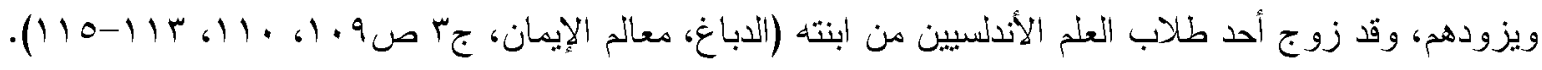

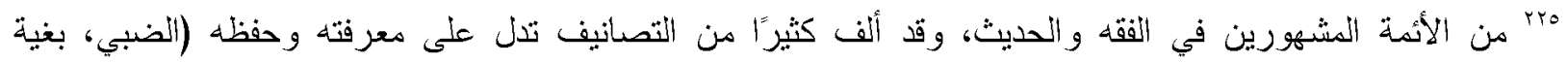

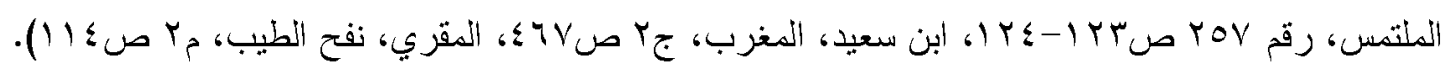

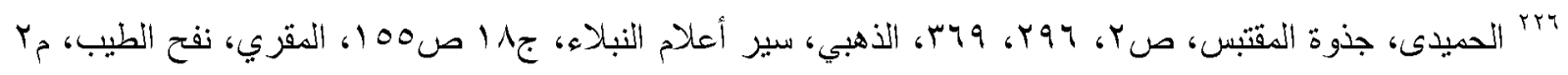




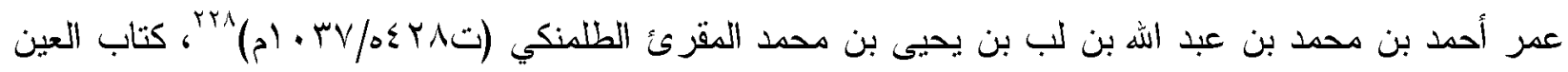
لابن سَنْرَ من الفقيه المحدث المشهور الإمام الرّحال أبي جعفر أحمد بن عَوْن الله بن حُدير البزاز القرطبي عن بهن

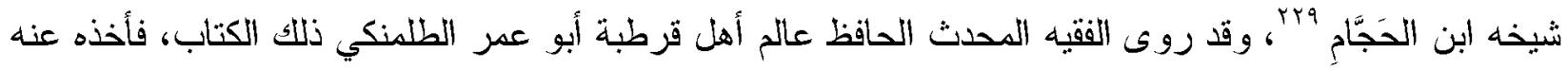

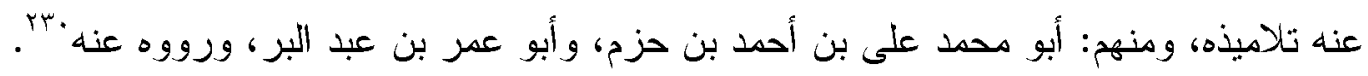

\section{الخاتمة}

بينت الدراسة دور الفقهاء القيروانيين والأندلسيين تلاميذ الإمام مالك بن أنس في التكوين الأول للمدرسة الفقهية المالكية ببلادهم. وكثفت عن التكوين العلمي المتين لعبد الله بن مسرور القيرواني المعروف بابن الحَجَّم،

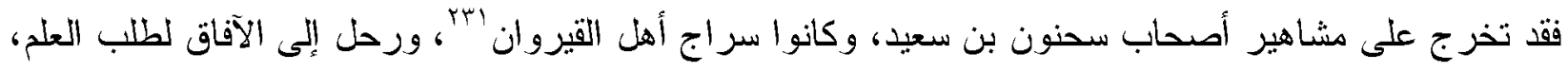

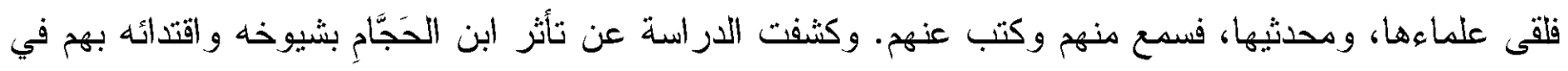

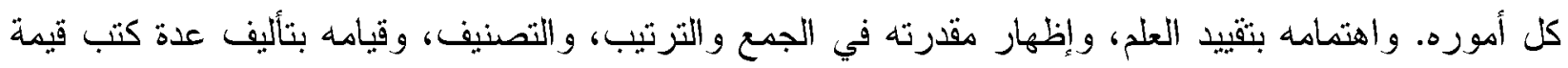

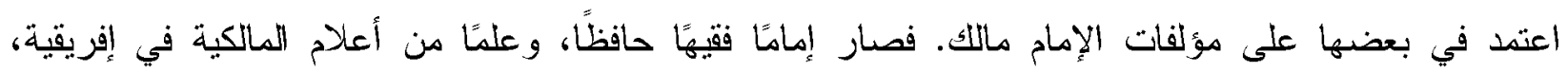
وكثنت الدر اسة أيضًا عن تبحر ابن الحَجَّامِ في رواية الفقه والحديث؛ وعن منهجه في تدريسهـا رواية وإِملاءًا، وحرصه على حضور جميع تلاميذه المترددين عليه مجالس سماعه، وحزمه مع غير المبالين منهم. وكثفت الدراسة عن وجوه استفادة طلاب العلم الأندلسيين الذين رحلوا إلى ابن الحَجَّامِ بالقبروان، فقد أخذوا منه مصنفاته سماعًا وكتابة، وكتبوا عنه ما انفرد به من روايات شيخيه عيسى ومحمد ابني مسكين، عن شيوخها

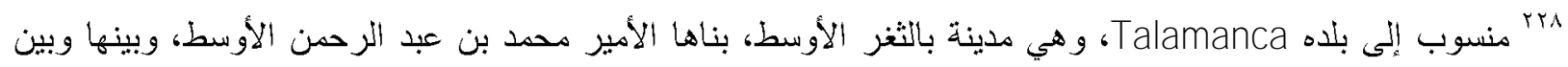

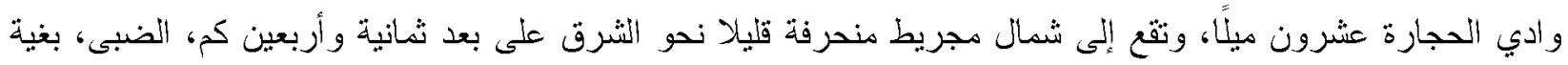

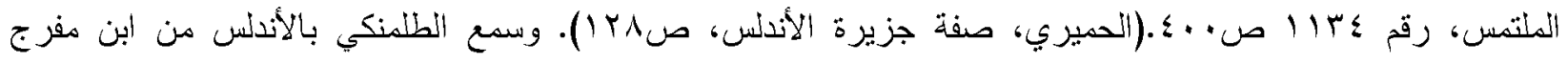

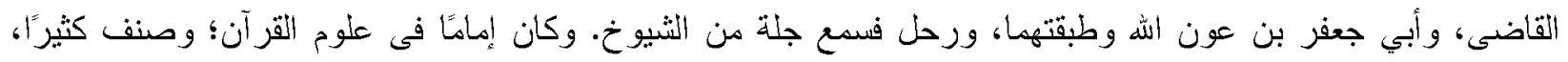

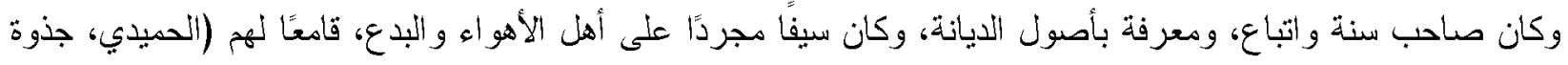

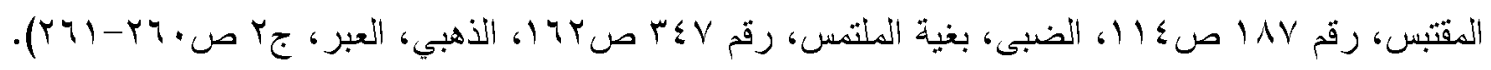

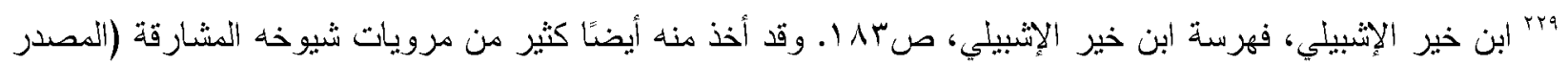

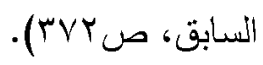

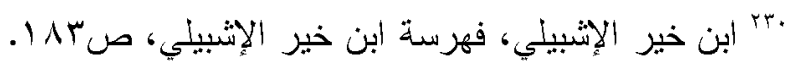

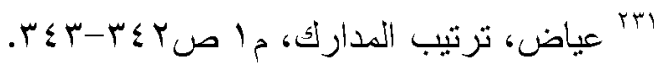




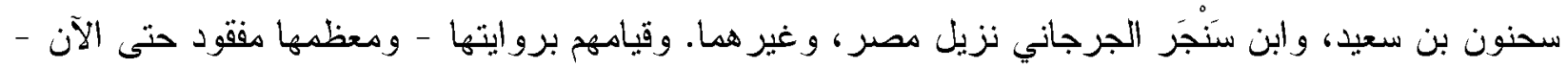
لتلاميذهم، فدونو ها في مؤلفاتهم، واحتفظو ابه، فقدمو بذلك خدمة جليلة للعلم وطلابه. وكثفت الدراسة أن أولئك الطلاب نقلوا عن شيخهم ابن الحَبَّام أيضًا أرائه النقدية عن مؤلفات علماء الأندلس المقيمين في إفريقية. وكذا ساهم ابن الحَجَّامِ في التكوين العلمي لتلاميذه القيروانيين، والو افدين من المغرب، والأندلس، وغيرها، فصار بعضهم من مشاهيز شيوخ الفقه والحديث ببلدانهم. وكثفت الدراسة عن موقف ابن الحَبَّام المالكي المعارض للمد الثيعي في إطار الصراع المذهبي بإفريقية وتأثر تلاميذه القيروانيين به، وكثفت أيضًا عن ميوله نحو الزهد و أنزر ذلك في نزوع تلاميذه القيرو انيين و الأندلسيين إلى الزهد و التصوف. وأخيرًا بينت الدراسة أن عطاء ابن الحَجَّاجٍ لطلاب العلم استمر بعد وفاته من خلال تتلمذهم على مشاهير طلابه القيروانيين، و انتفاعهم بكتبه التي وقفها على لى طلاب العلم، ومن خلال سماعهر رواياته من تلاميذه الأندلسيين، خاصة رو اياته لكتب ابن سَنْجرَ . 